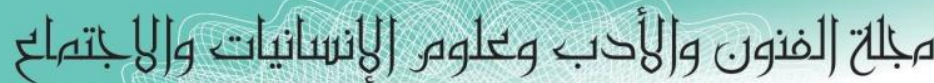
Journal of Arts, Literature, Humanities and Social Sciences

ISSN online: 2414 - 3383

ISSN print: 2616 - 3810

2019 نوفر نوبر Volume (45)
(45) (40) November 2019

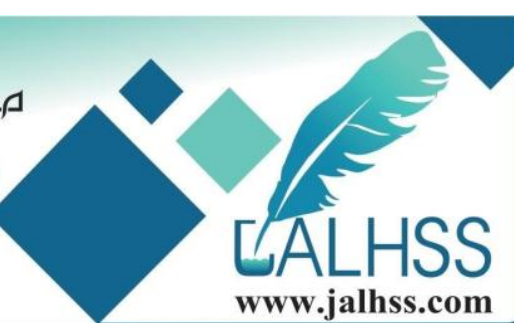

www.jalhss.com

\title{
الواقعية التجريدية في أعمال الفنان دلثاد اسماعيل
}

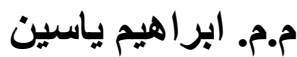 \\ قسم التشكيلي - كلية الفنون الجميلة ـ جامعة صلاح الدين الدين - كردستان العراق \\ ايميل: Ibrahim_t88\&yahoo.com
}

التجريد في الفن هو اعادة صياغة و اقع ما بالاعتماد على صيغ او وسائل مجردة كاللون و الخط بانو اعه و الضوء و غير ها. وبما ان الفن يختلف عن الواقع والحياة فهو عمل مجرد لا ينتمي الى قو انين الو اقع المادي. والواقعية التجريدية في تجربة الفنان "دلثاد اسماعيل" هي موضوع البحث الحالي والذي يتناول (الواقعية التجريدية في أعمال الفنان دلثاد اسماعيل)، من خلال رصد خصائص عينات من اعماله الفنية وكيفية تجسيد الصياغات الثكلية الواقعية التجريدية في لوحاته، أضافة الى كثف خصائص اعماله وقدرته على التنقل بين الجمالي والوظيفي ومايحققه من انجاز ابداعي في الثكل والمضمون. وتوصل الباحث من خلال تحليل اعمال الفنان

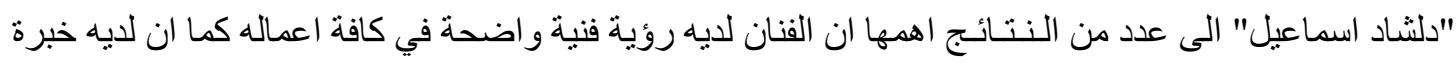
في تمثيل الاشكال والتعامل بذهنية واثارة عالية من خلال الملامس و الحركات والالوان. وقد نجح في عفوية الحركة والارتجال واظهار التكوين في لوحاته من خلال ضربات فرشاته ووضع لمسات بر اقة بألوان رمادية فضية وفضاءات لونية معينة وهما تعتبران من سمات البارزة للواقعية التجريدية وهناك شعور وادر اك تام بالمادة و الملمس للأشكال المجسة وقد جسد الفنان ميزة خاصة الا وهي تلوين اللحظات المعبرة من خلال سلسلة الصور التي تركز على الأوقات المعينة من اليوم ومن خلال الإضـاءة ومجمو عة من الألوان المنسجمة التي تخلق مزاج لاى المشاهد تجعله يشعر باحساس المكان، و لقد استخدم الوانا وردية وبرتقالية عكست على سطوح

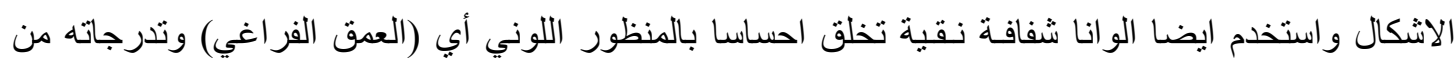
خلال استمر ارية اللون من الغروب للتعتيم. 


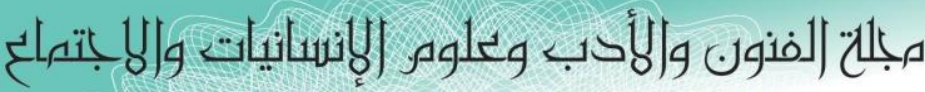

Journal of Arts, Literature, Humanities and Social Sciences

ISSN online: 2414 - 3383

ISSN print: 2616 - 3810

2019 نوفير

Volume (45)

(45) (40)

November 2019

\section{The Abstract Realism in the Works of the Artist Dilshad Ismael Aldoskani}

\section{Assist. Lect. Ibrahim YAssin}

\section{ABSTRACT}

The research deals with the subject (abstract realism in the works of the artist Dilshad Ismail). It investigates its artistic properties and how to embody them in his paintings through the abstract realism term, in addition to uncovering its color and optical properties in the embodiment of the contemporary instant color sights of streets, buildings, architectures cars and contemporary cities at different times of day and night, and in rainy atmosphere. The research has yielded the following results: it showed light and color effects for its brushes and the presence of touches of bright contact with the colors of gray silver as an aesthetic characteristic of the painting and certain color spaces, which are regarded as hallmarks of abstract realism. There is a feeling and full realization to the material and texture of embodied shapes. The artist has embodied a special feature, namely, coloring moments expressed through a series of images that focus on specific times of the day and through lighting creates a set of harmonious silver-gray colors where these colors create a mood for the viewer to make him feel sense of the place. The pink and orange colors were used as a result of the color and light reflections that reflected on the surfaces of the shapes. Moreover, there is a use of pure transparent colors, creating a sense of the color perspective (spatial depth) and its gradations through color continuity from sunset to darkening. 


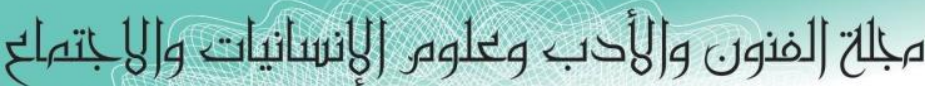

Journal of Arts, Literature, Humanities and Social Sciences

ISSN online: 2414 - 3383

ISSN print: 2616 - 3810

\section{9 نوفهبر \\ Volume (45)}

(45) (40)

November 2019

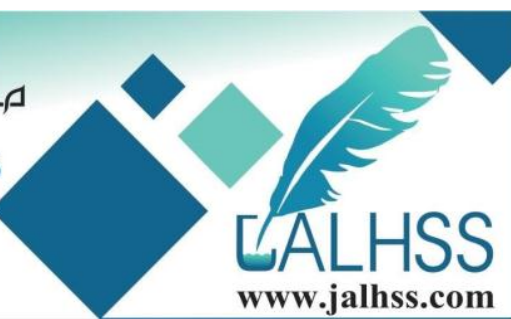

\section{الفصل الاول \\ مشكلة البحث واهميته}

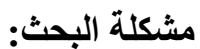

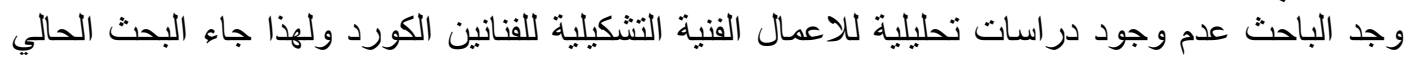

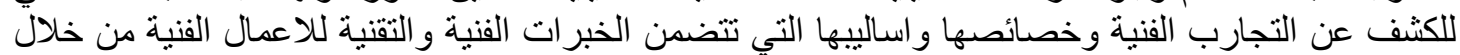

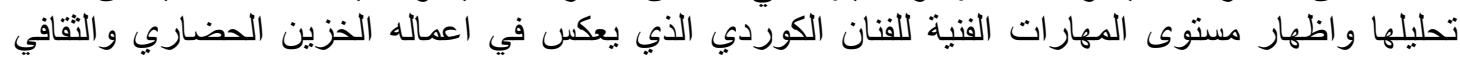

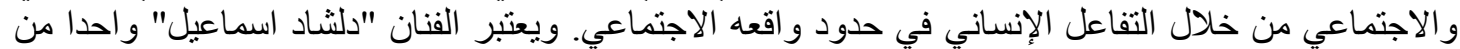

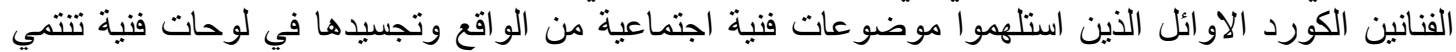

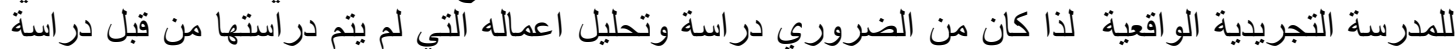

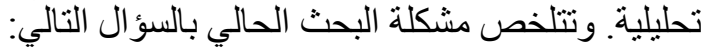

(هل تعكس تجربة الفنان دلثداد اسماعيل خصائص ومميزات التئ المدرسة التجريدية الواقعية)

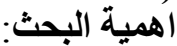
تكمن اهمية البحث الحالي في انه:

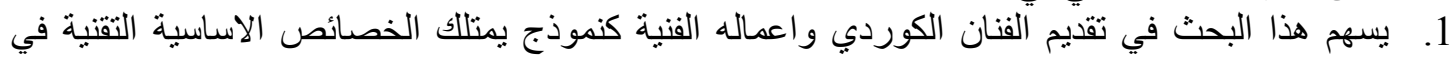
التعامل مع السطح التصويري بحرفية ومهارة عالية.

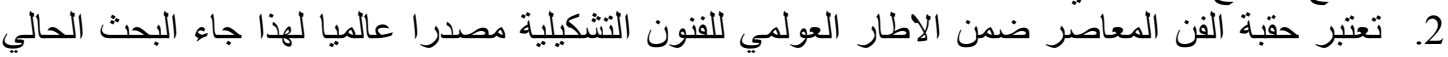

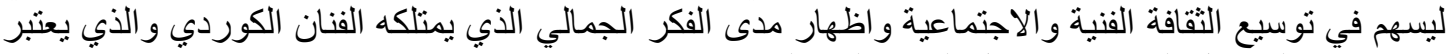

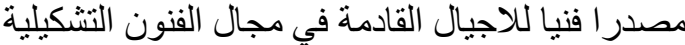
3. يعتبر هذا البحث اضافة جديدة في حقل الدر اسات التحليلية في تاريخ الفن المعاصر لاقليم كوردستان.

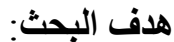

كثف السمات الو اقعية التجريدية في اعمال الفنان "دلثـاد اسماعيل".

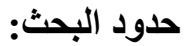
تحدد البحث الحالي بالاتي: 1. الحدود الزمانية: الاعمال الفنبة من عام 2014 الى عام 2016.

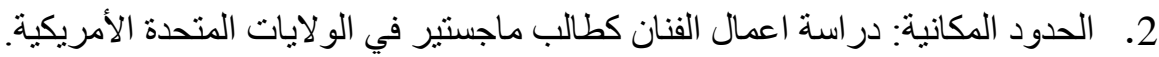
3. الحدود الموضو عية: اسلوب الو اقعية التجريدية في اعمال الفنان "دلثاد اسماعيل". تعريف المصطلحات

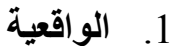

لغة: "وقع: الو اقع وقع وقوع: طائر و اقع: قائم على الثجر أو في وكنه، يقال (رجل و اقع الطير) أي ساكن

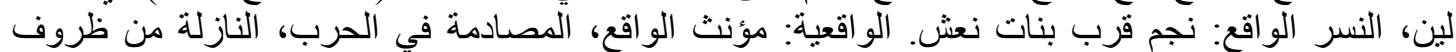

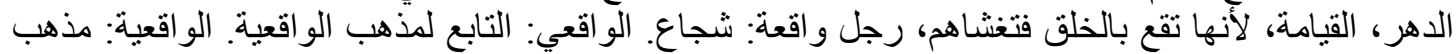

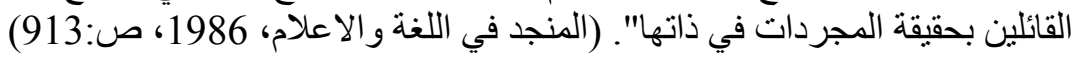

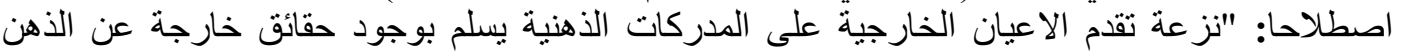

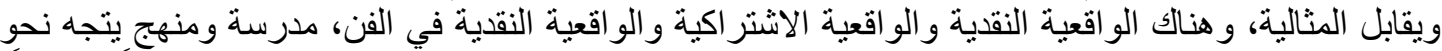

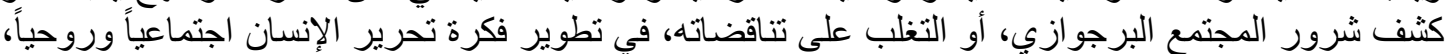

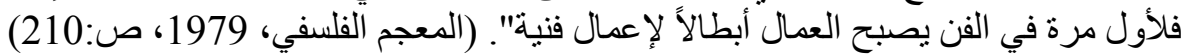
2. الواقع والواقعية

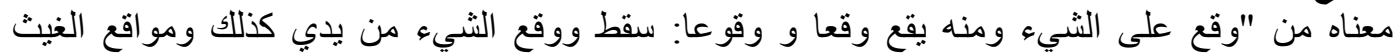

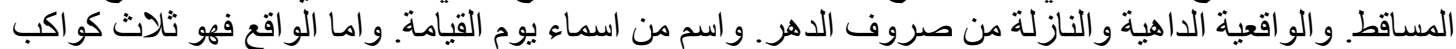

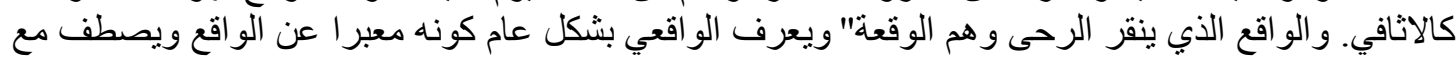

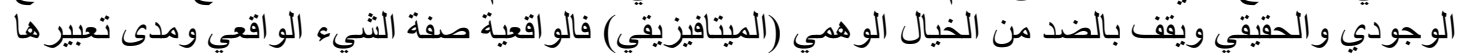

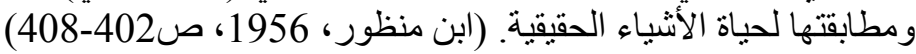




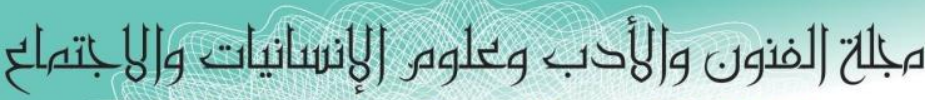
Journal of Arts, Literature, Humanities and Social Sciences

ISSN online: 2414 - 3383

ISSN print: 2616 - 3810

2019 نوفير Volume (45)
العدد (45) November 2019

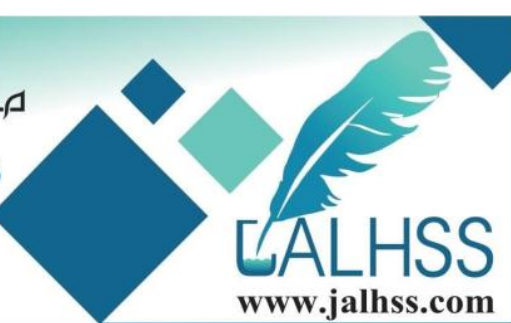

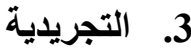

التجريد هو "التنظير اي المعرفة المنظمة للواقع التي تعكس العالم الموضوعي وجوانبه ، يستخلصها العقل

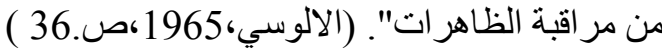

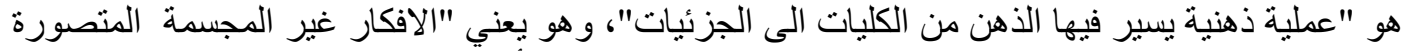

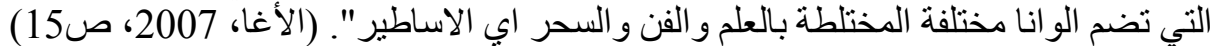

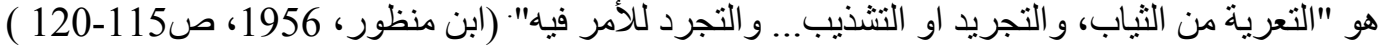
التعريف الاجرائي

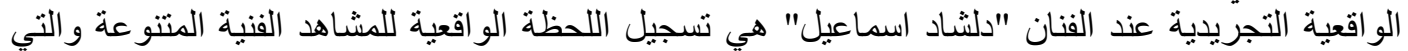
تحمل خصائص الو اقع وفق اشتغالات فنية تقنية تنتج اسلّوبا تجريديا نابعان الفيل من الو اقع.
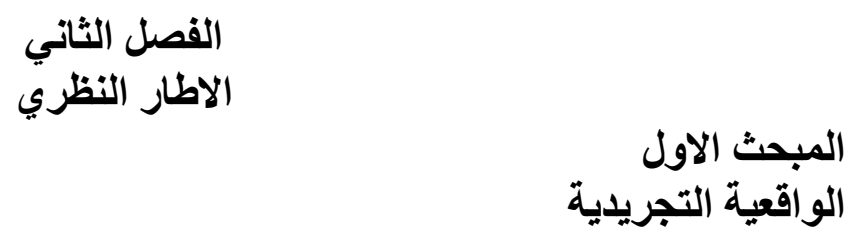

مقدمة

تعتبر الفترة التي تمند منذ نهاية القرن التاسع عشر وبداية القرن العشرين هي ولادة الفن الو اقعي التجريدي

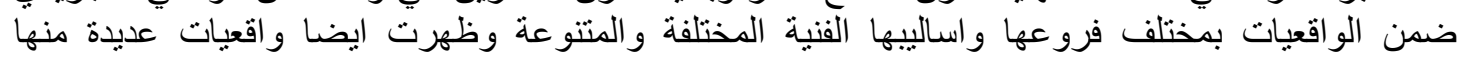

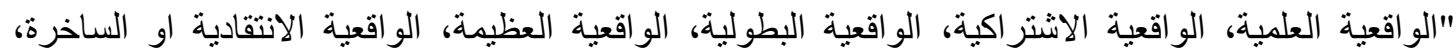

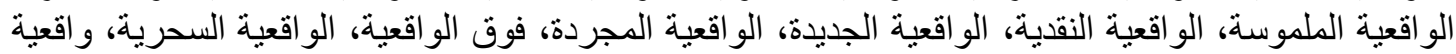

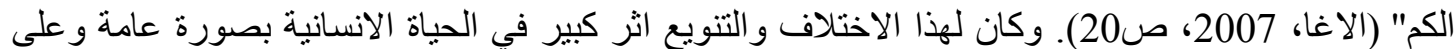

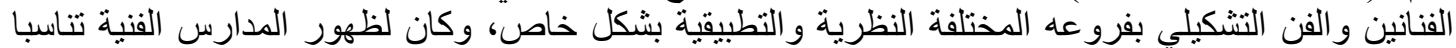

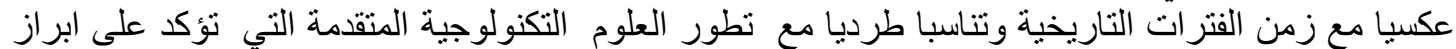

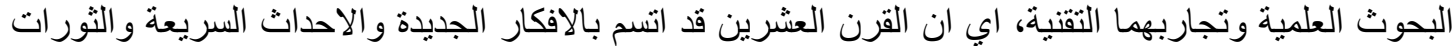

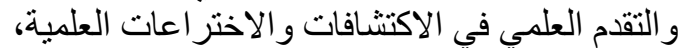

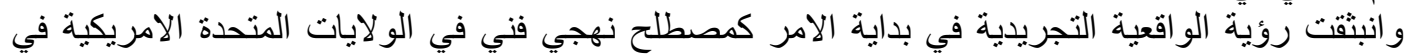

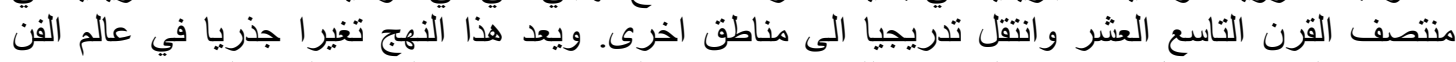

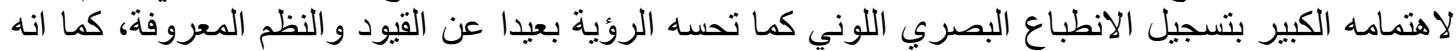

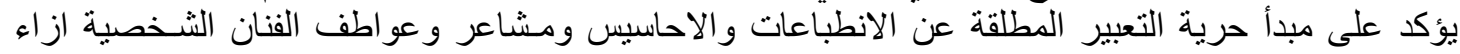

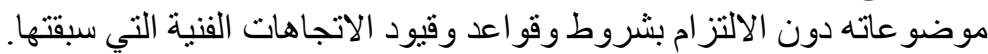

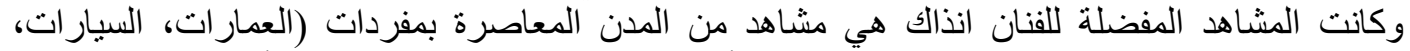

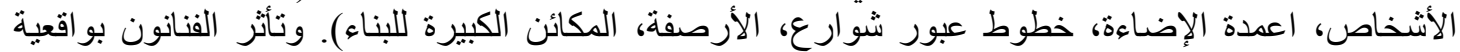

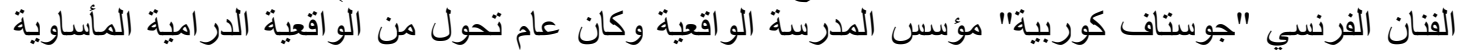

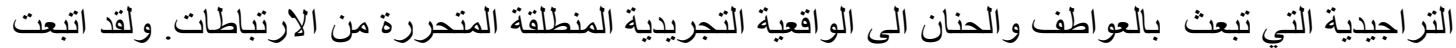

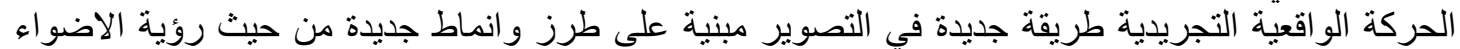

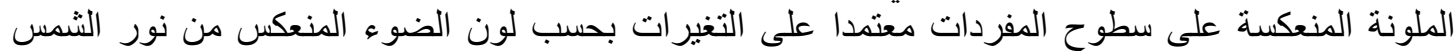

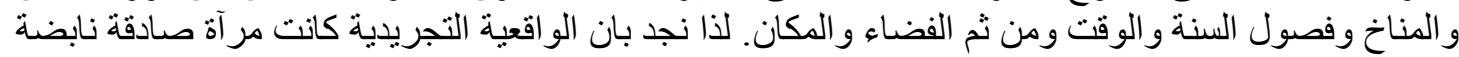

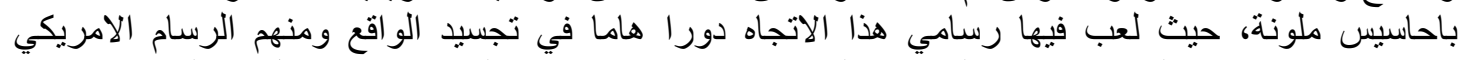
الى "Jeremy Mann"

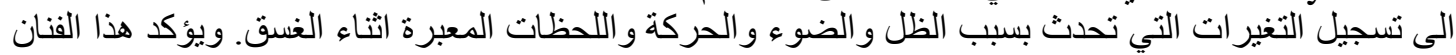
على ان تكون الخطوط العمودية و الافقية متشابكة مع بعضها البعض وهذا يخلق شعورا بالحركة. ومن خلال 
مبلحت (لفنون والأدب وعلوه الإنسانيات و|لهابتهاع Journal of Arts, Literature, Humanities and Social Sciences

ISSN online: 2414 - 3383

ISSN print: 2616 - 3810

\section{9 نوفمبر \\ Volume (45)}

(45) (4)

November 2019

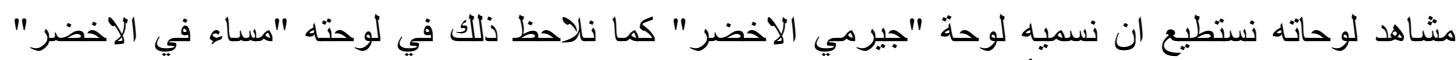

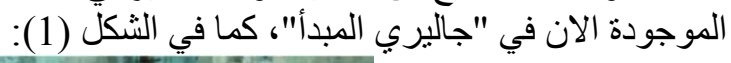

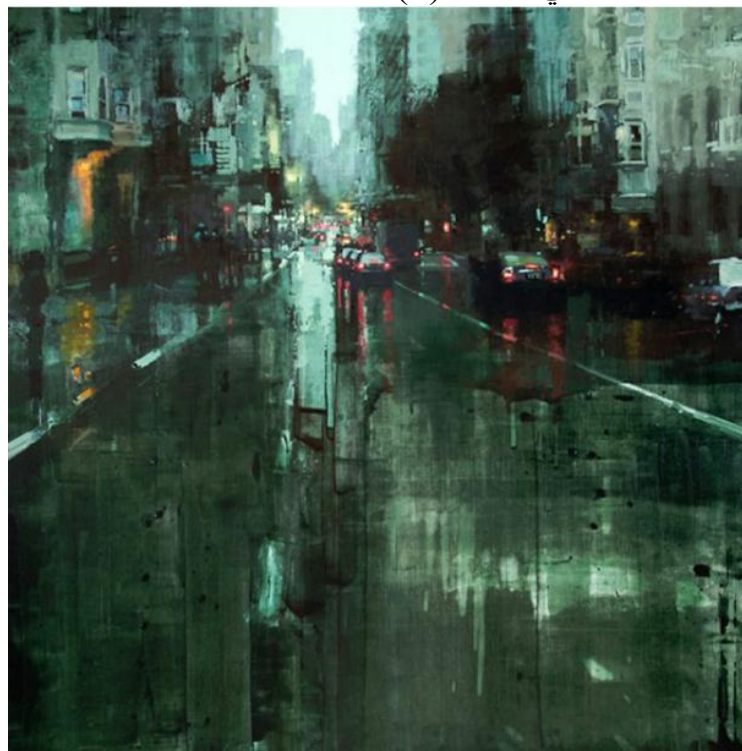

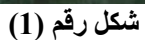

جيرمي "مساء في الاخضر"، زيت على خثب (1)×36)

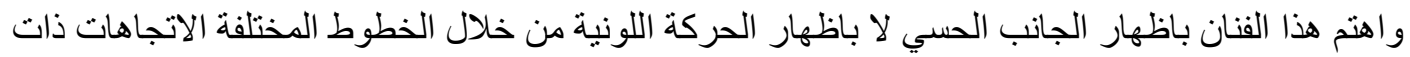

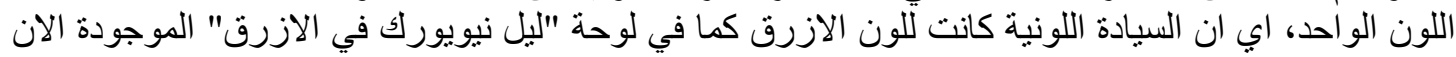
في جاليري "The John Pence"، كما في الثنكل (2):

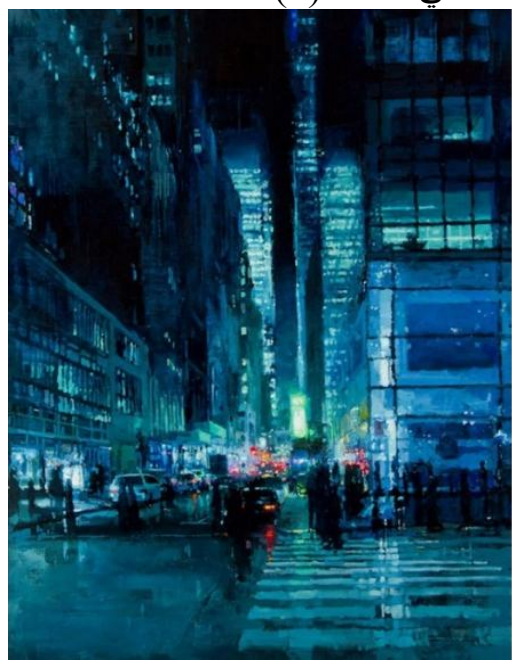

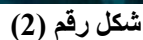

جيرمي "ليل نيويورك في الازرق"، (48×36)

لقد اطلق الفضاء الملون والطبيعة الخلابة قدرات الفنانين الهائلة في رسم وتصوير الو اقع التجريدي و هذا ما

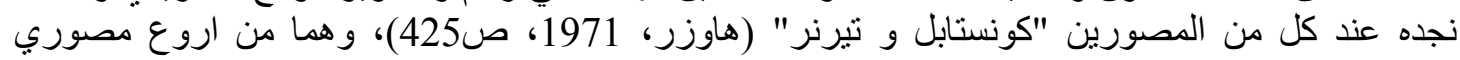

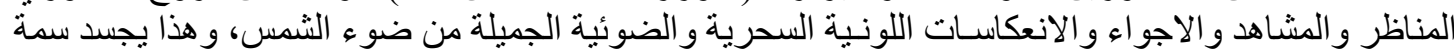
الواقعية التجريدية المتكونة من خليط من الاتجاهات الثناث و هي (الو اقعية، الانطباعية، التجريدية) كما في لوحة التها 


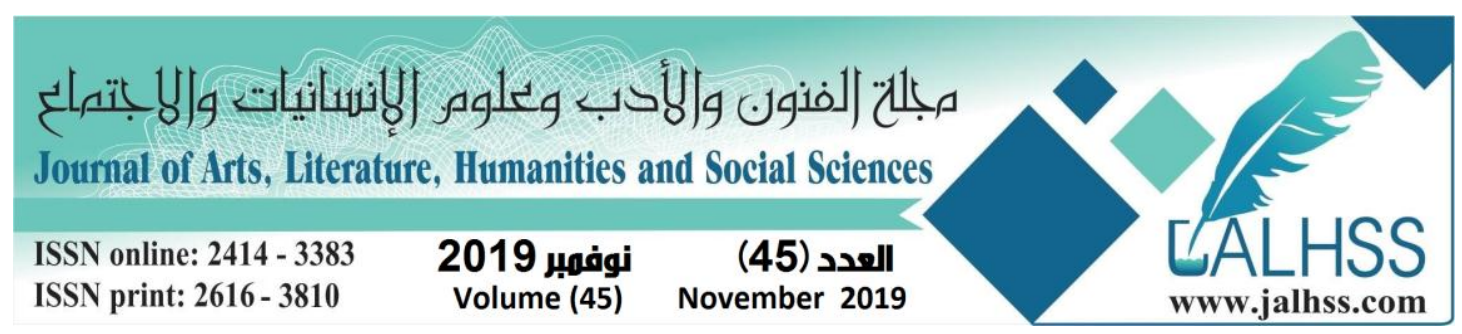

الفنان الفرنسي الانطباعي "كلود مونيه" وهي "انطباع شروق الشمس 1872" (محمود، 1981، ص37) كما في الثكل (3): (1)

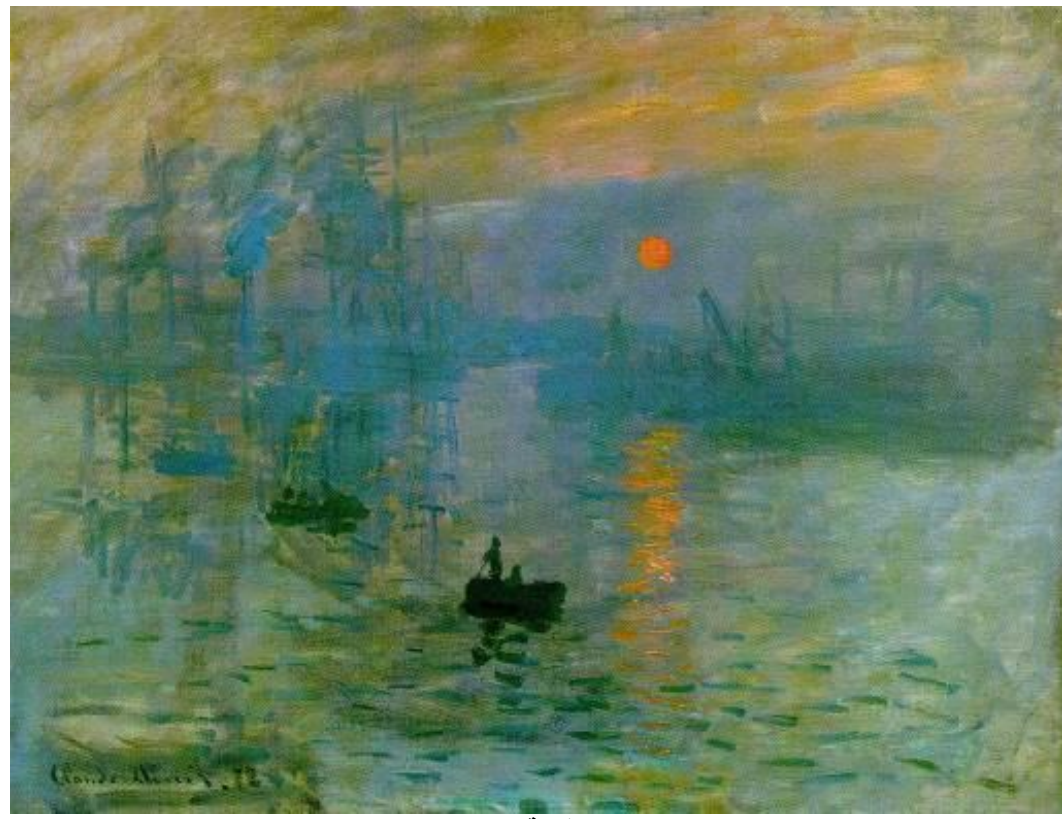

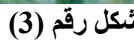

كلود مونيه "انطباع شروق الثمس"، مشهر من ميناء لوهافر، 1872

و التي رسم فيها الفنان مرسى ميناء لوهافر في صباح مبكر غارقا بضباب كثيف بضربات العات تلقائية مختزلة

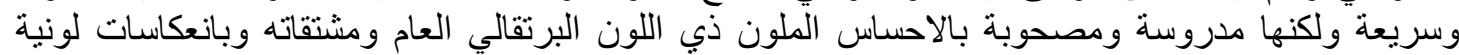

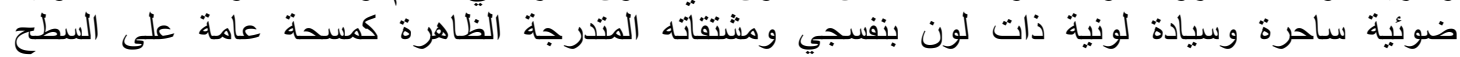

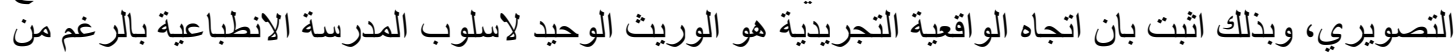

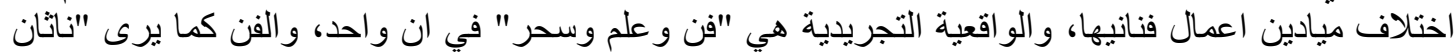

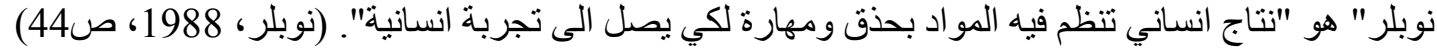

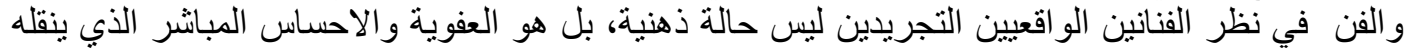

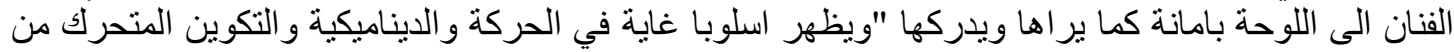

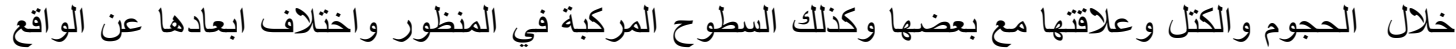

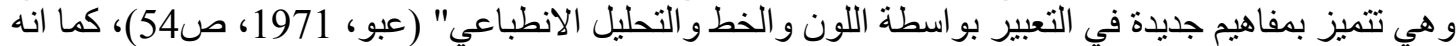

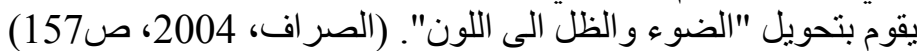

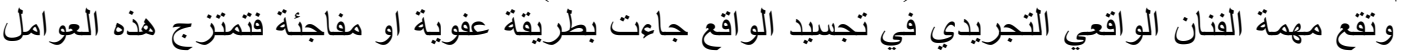

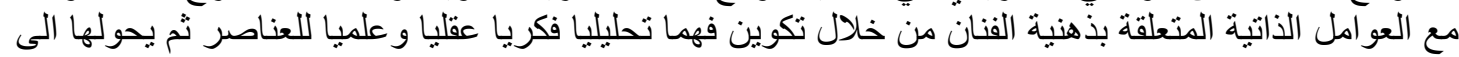

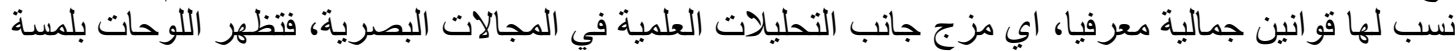

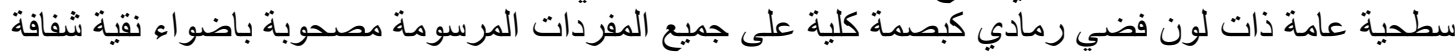

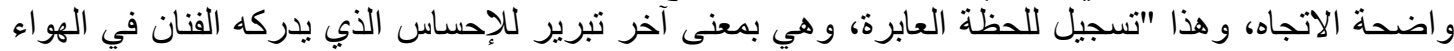

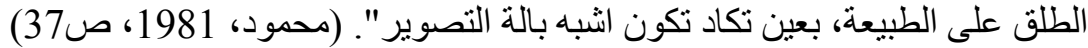

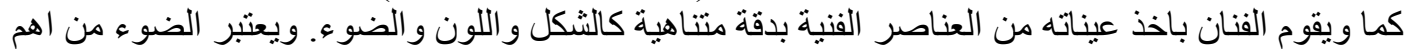

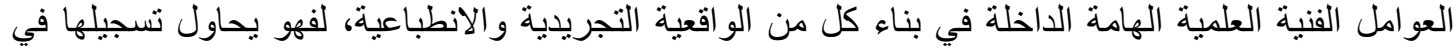
لحظة ما ولتحقيق ذلك يستخدم الالوان الزيتية في مساحات متداخلة ذات الشكال و اضحة بدلا من خلطه على لوحة 


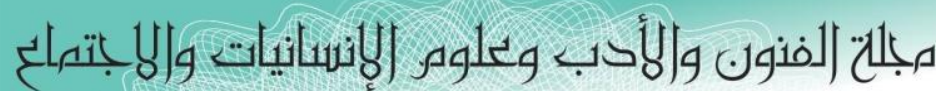
Journal of Arts, Literature, Humanities and Social Sciences

ISSN online: 2414 - 3383

ISSN print: 2616 - 3810

2019 نوفير Volume (45)
العدد (45) November 2019
LALHSS

www.jalhss.com

الالوان، لذا كان للضوء سيادة، "و عندما سئل الفنان مانيه عن اهم شخصية في لوحته فأجاب قائلا بان اهم

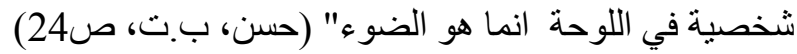

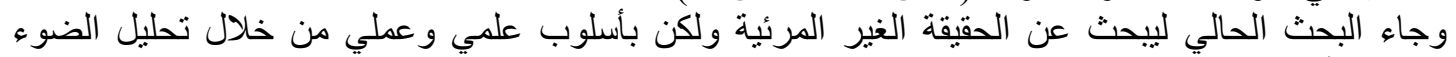
ودر اسة تأثيره على سطح المرئيات في اعمال الفنان دلثاد "اسماعيل" كما في الاشكال ادناه (4، 5، 6، 7ن 7):

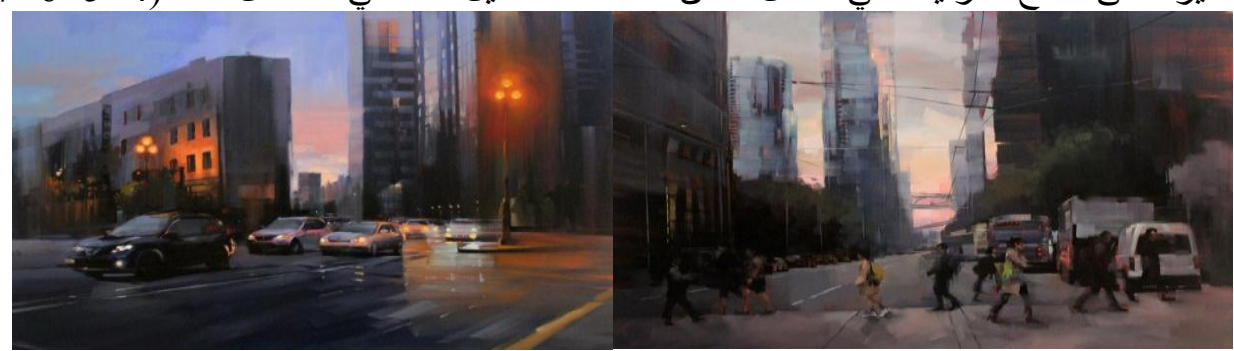

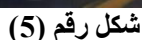
دلثاد "شارع بيل"، زيت على جنفاص (24×2015)

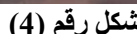

دلثاد "اسقط شارعا"، زيت على جنفاص (24) 2015)

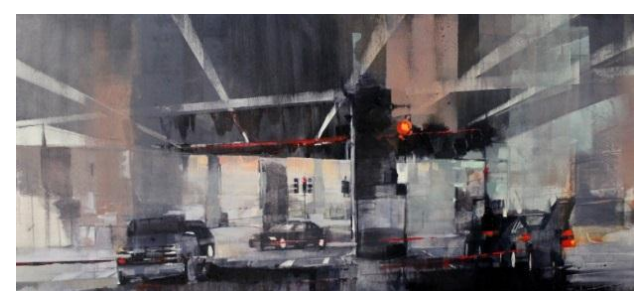

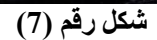
دلثاد "شارع المهمة"، زيت على خثب (2016)

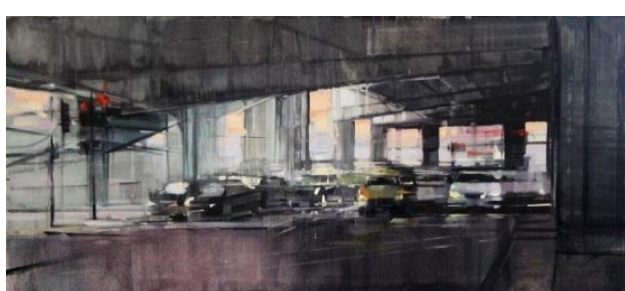

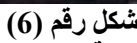

دلثاد "شارع المهمة"، زيت على خشب (8) 2016

لقد عنيت الو اقعية التجريدية بنسجيل الانطباع الكلي عن الاشياء باسلوب معين او بطريقة ما توحي للمشاهد

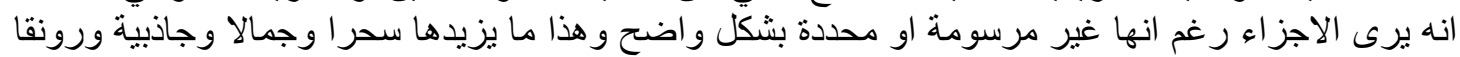

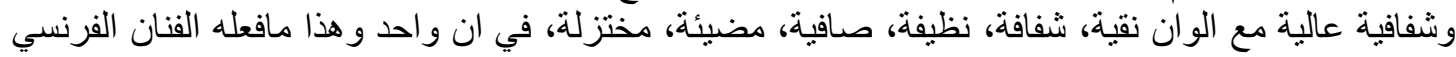

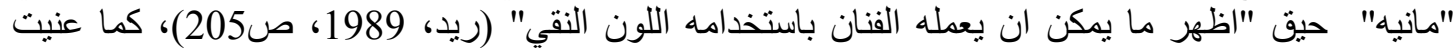

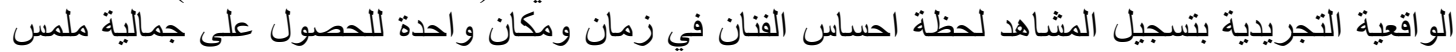

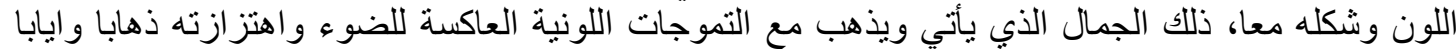

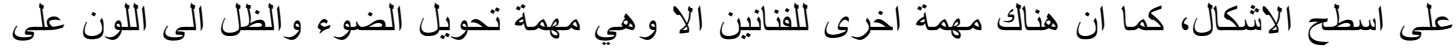

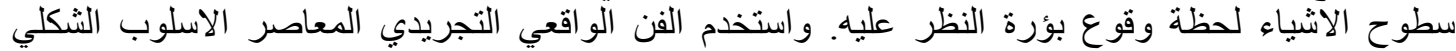

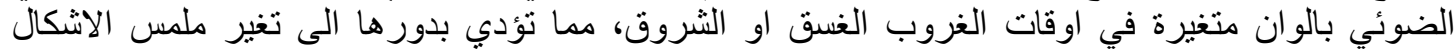

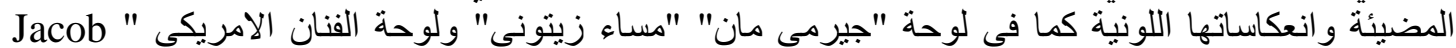
Dhein 


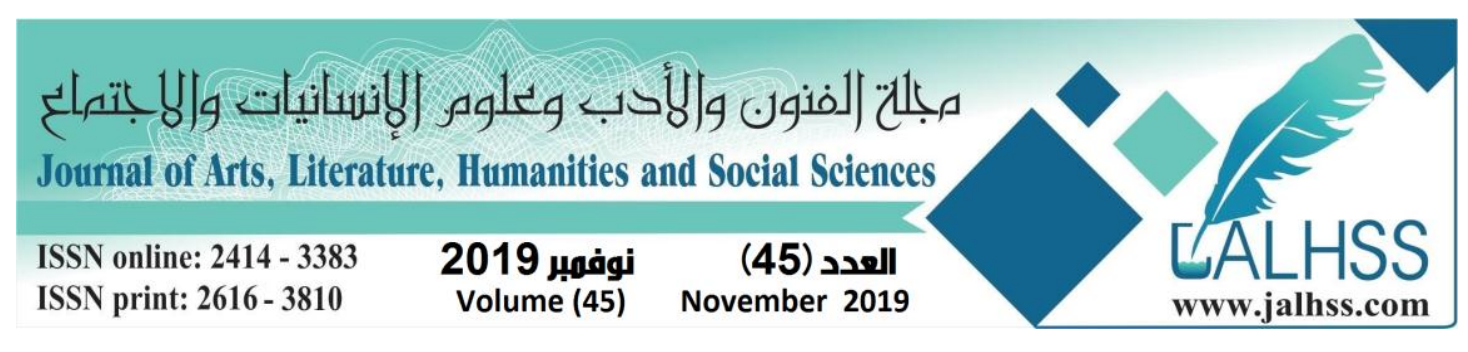

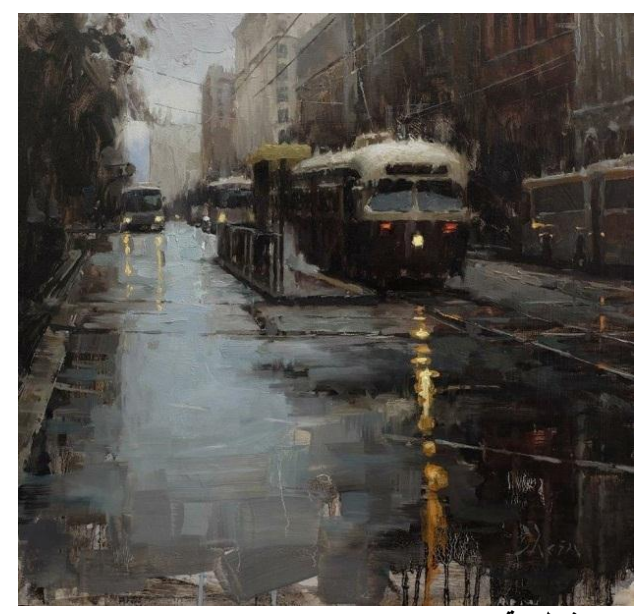

شكل رقم (9) مغري

Dhein

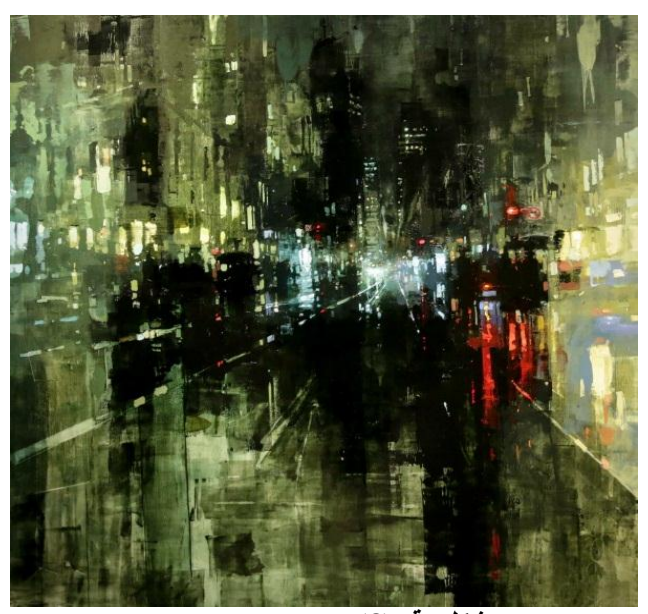

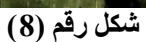

مان "مساء زيتوني"،

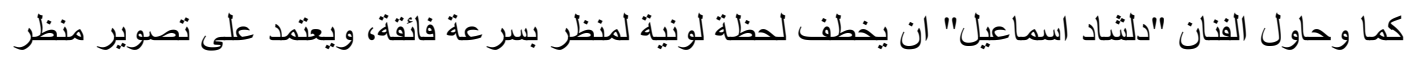

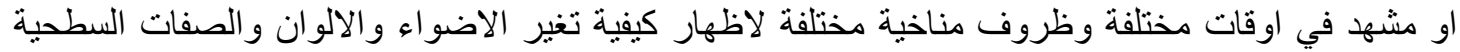

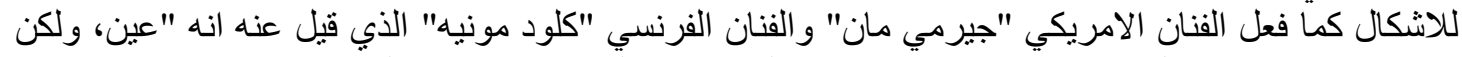

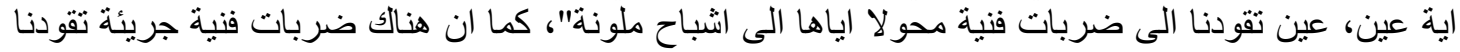
الى لمسات احادية اللون كلمسة عامة على سطح اللوحة كصفة جديدة للواقعية التجريدية. (الاغا، 2007،

ص117)

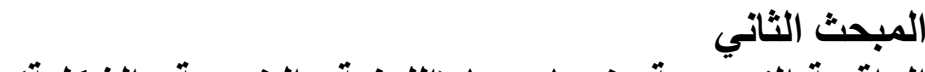 الواقعية التجريدية خصائصية خهائية (اللونية والضوئية والثكلية)}

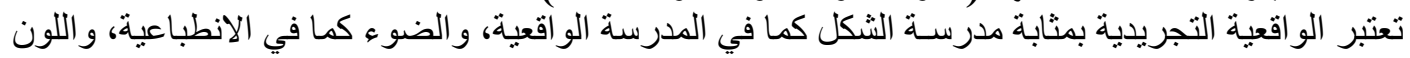

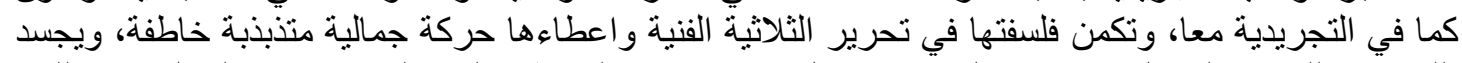

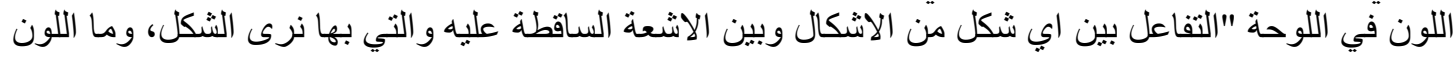

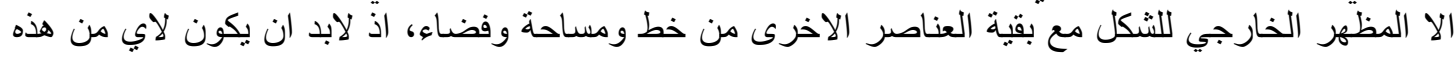

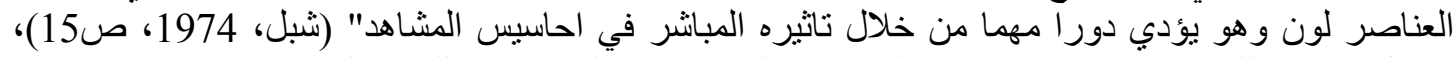

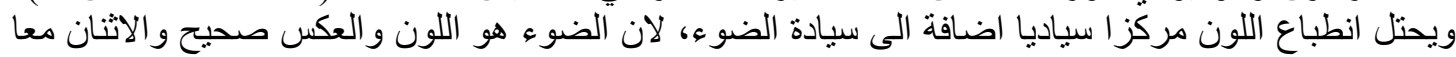

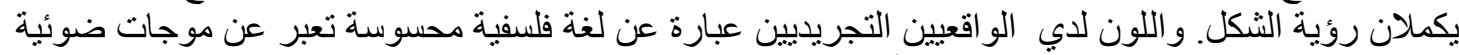

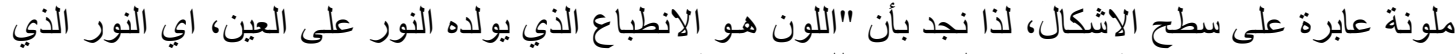

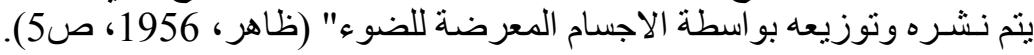

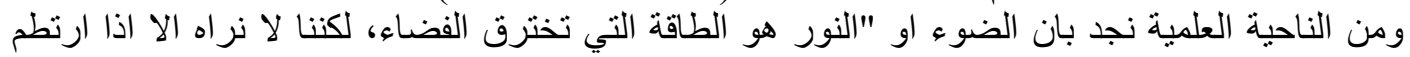

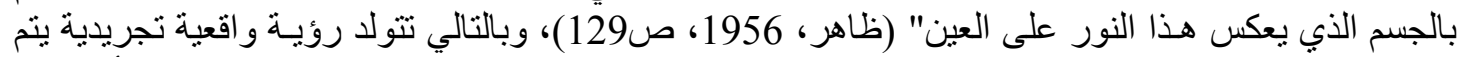

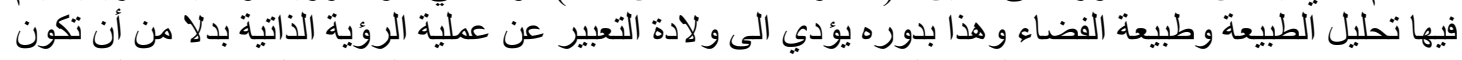

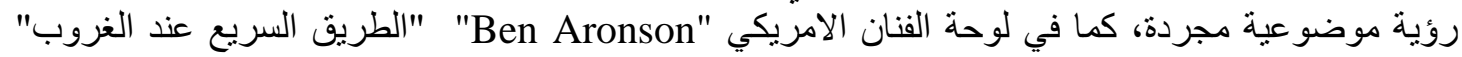

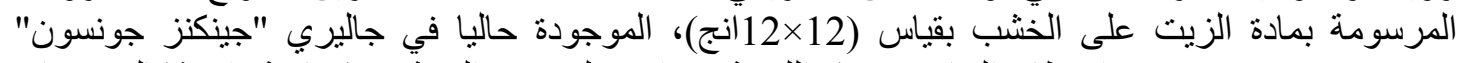
"Jenkins Johnson"

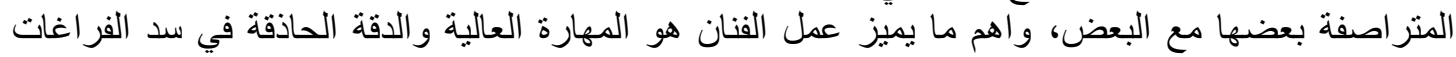

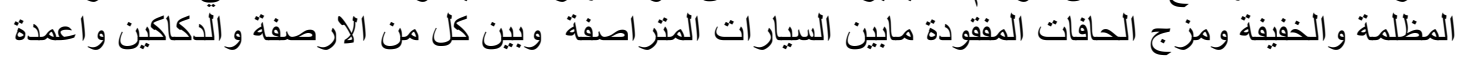

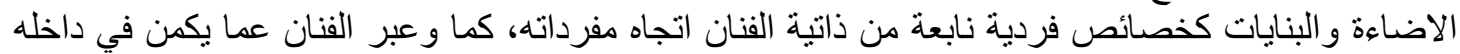

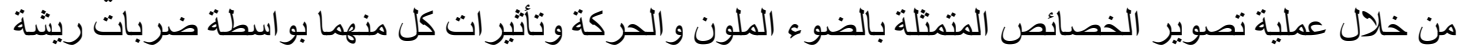




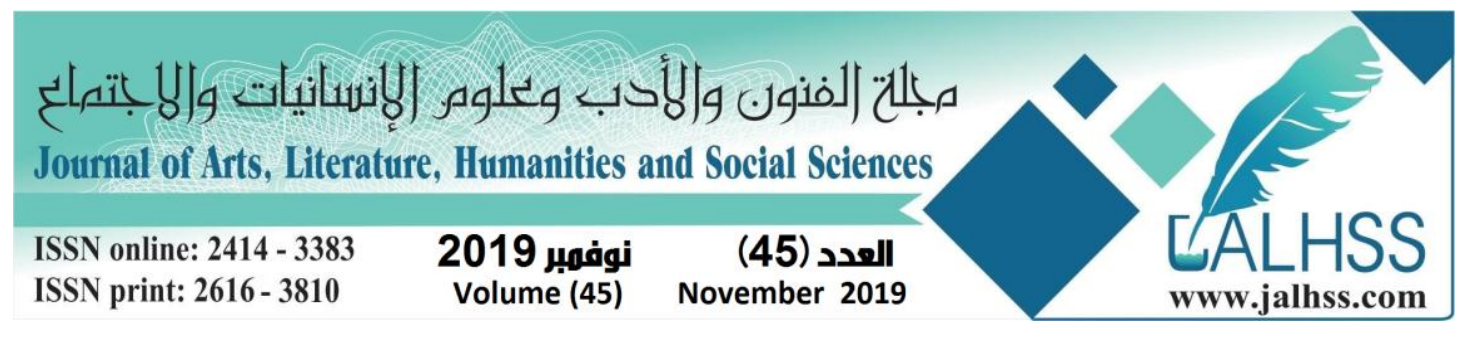

الفنان كما في لوحته "عبر المدينة" المرسومة بمادة زيت على الخشب بقياس (12×انعانجانج) الموجودة في

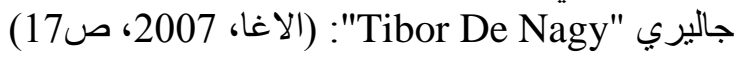
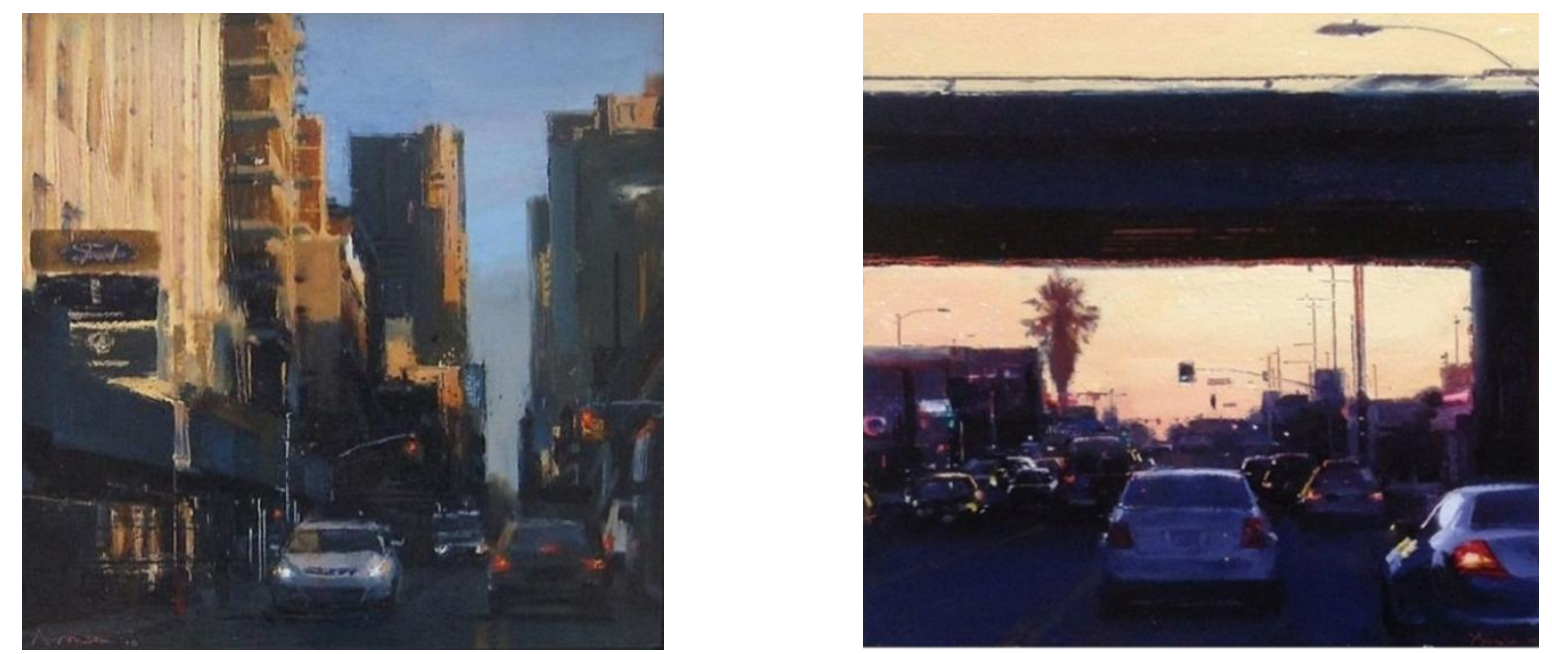

اشار "سيزان" (1839-1906) ان اهم ما يميز هذ الاتجاه عن غيره من المدراس الفنية هي "سمات

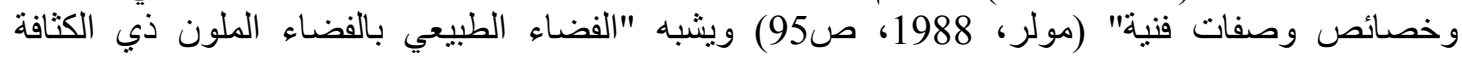

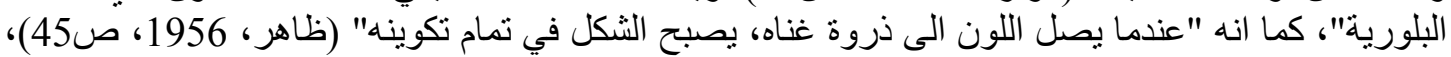

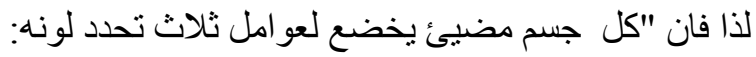

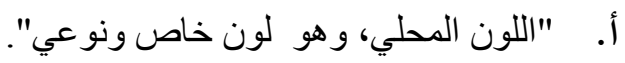

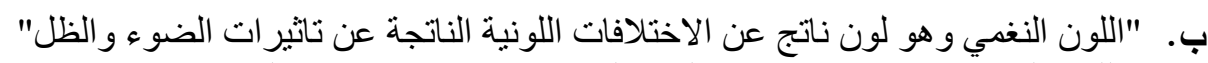

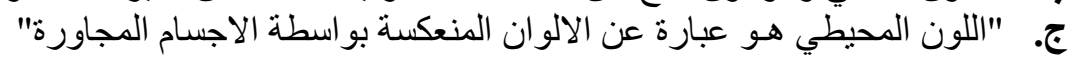

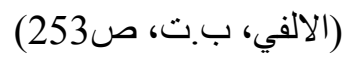

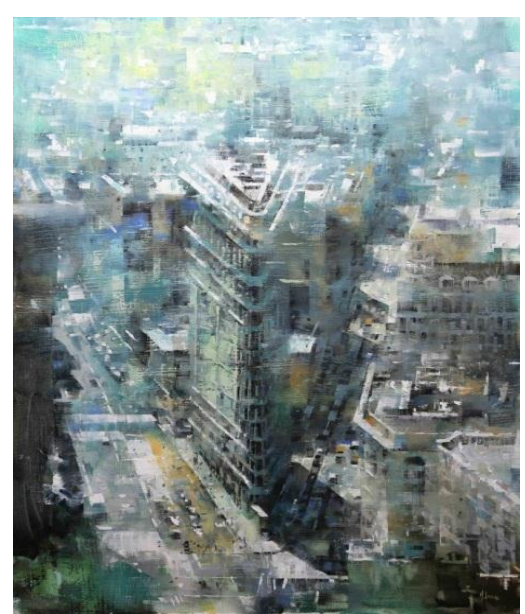

مارك "في الاخضر"، 2016
كما في الثكل (12) و الثكل (13):

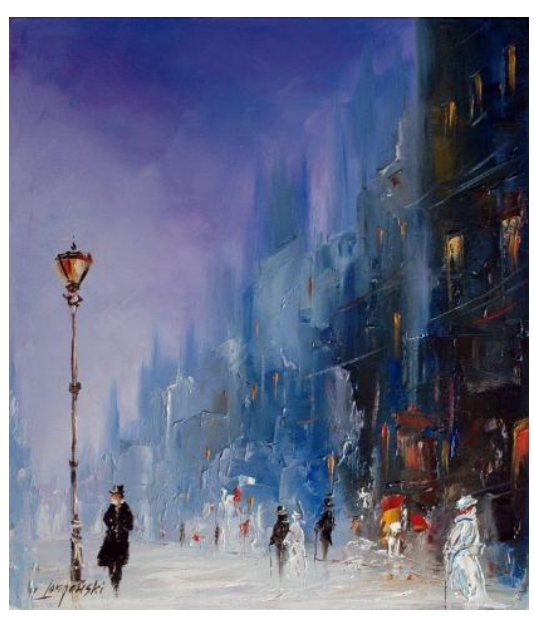

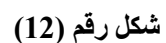

مارك "مساء زرقاء بنفسجي"، 2016 


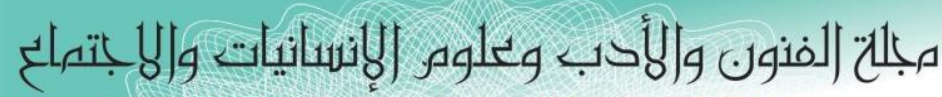
Journal of Arts, Literature, Humanities and Social Sciences

ISSN online: 2414 - 3383

ISSN print: 2616 - 3810

\section{9 نوفر Volume (45)}

(45) العدد (4015) November 2019

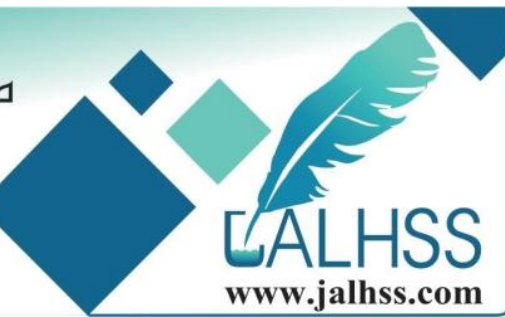

ويعتبر اللون عنصر ا اساسيا من عناصر الفن التشكيلي وبالاخص في فن الرسم وهو ايضا "عنصر من عناصر

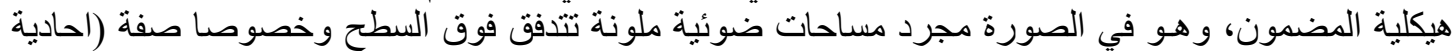

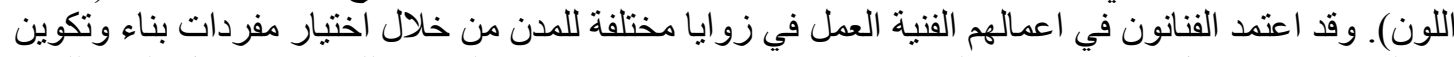

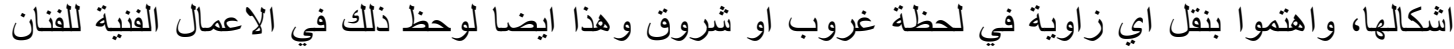
"دلثاد اسماعيل" حيث الانطباعات الحسية التي تعكس ادركا للحظة اثناء التقاطها. كما في الاشكال (14، 15):

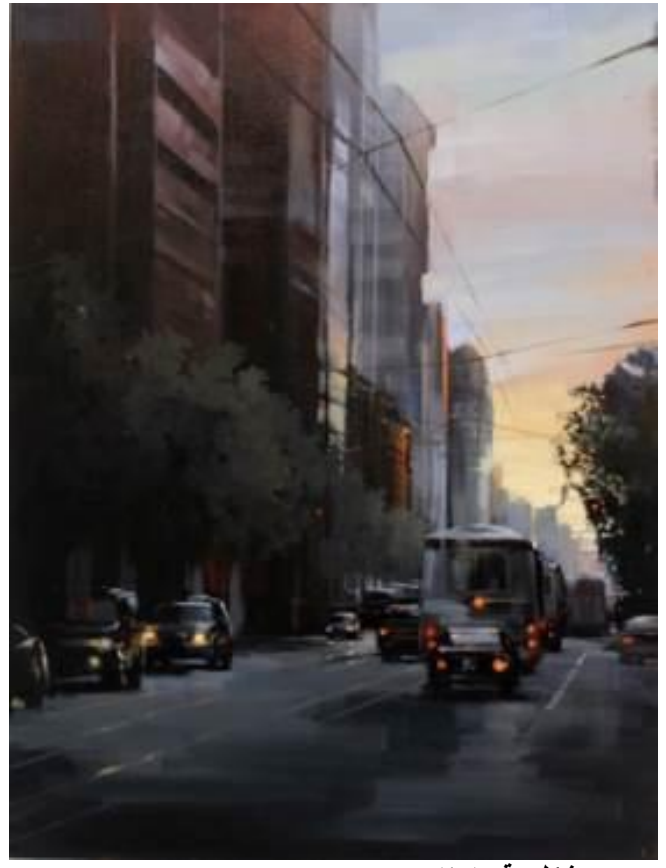

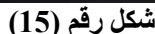

"شارع الاخضر"، نفط على جنفاص(24×30)، 2015

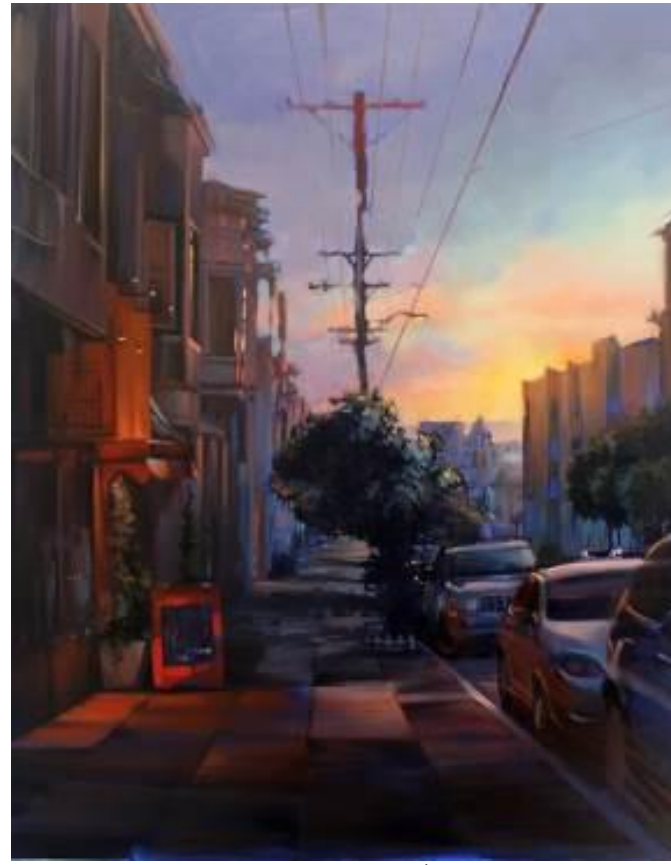

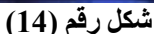

"شارع السوق"، نفط على جنفاص، (18× (24))، 2015

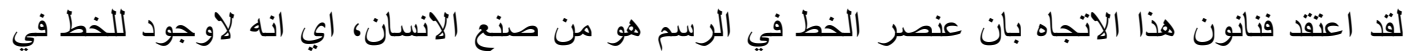

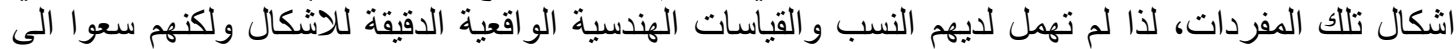

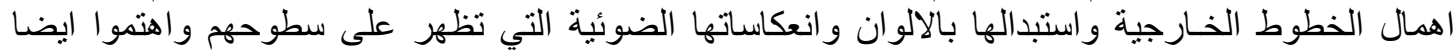
بمزج الحافات المفقودة بين مفردات المشهد، وكذلك لم يههل الجانب التشريحي لهذه الاجسام ولكن بدلوها

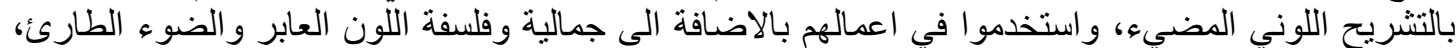
جمالية اخرى الا و هي جمالية الانطباع الذاتي التي احدثت من قبل الفنانين الو اقعيين التجريديين كما في الثكل

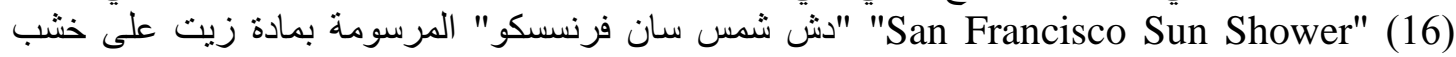

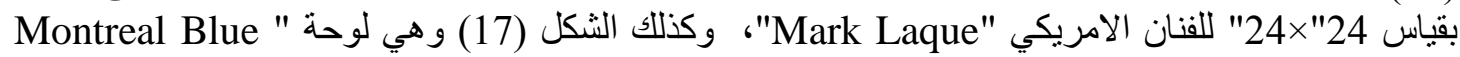
"Rain المرسومة بمادة زيت على الخشب وبنفس القياس بضربات لونية ضوئية عريضة جريئة وواسعة الانة خاطفة للحظة معينة. 


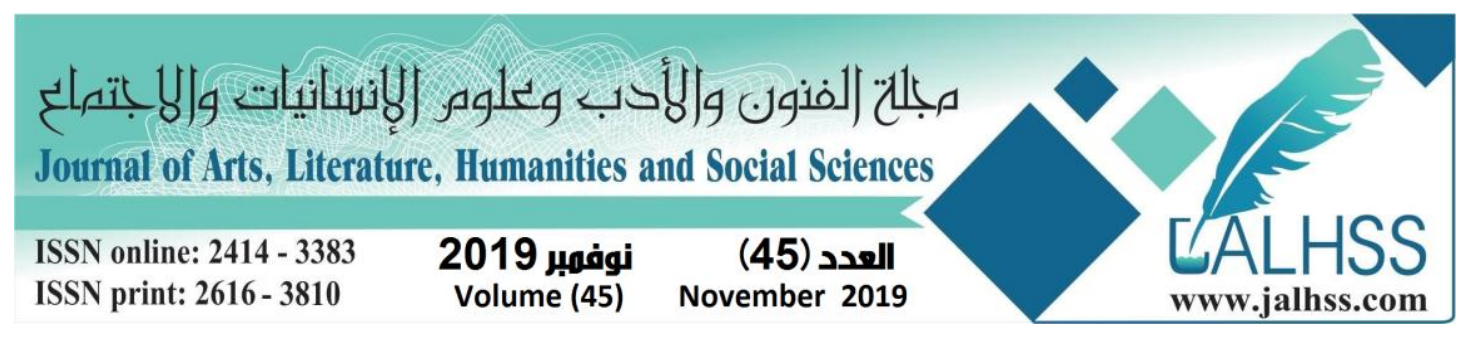

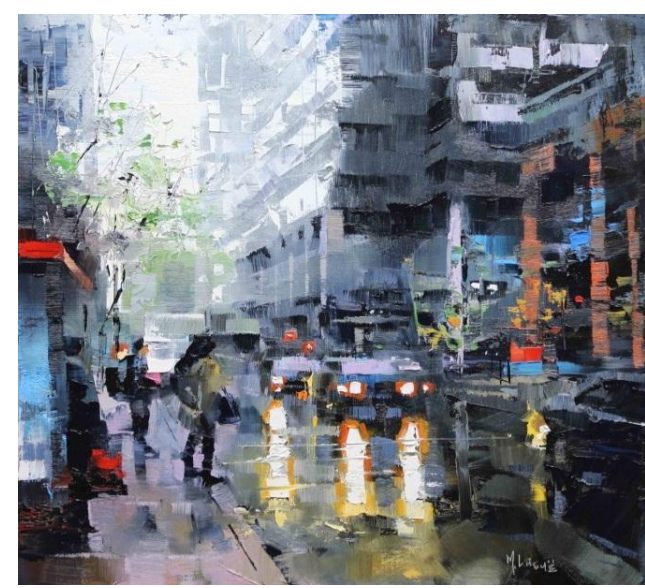

شكل رقم (16) مونتري)

Lague

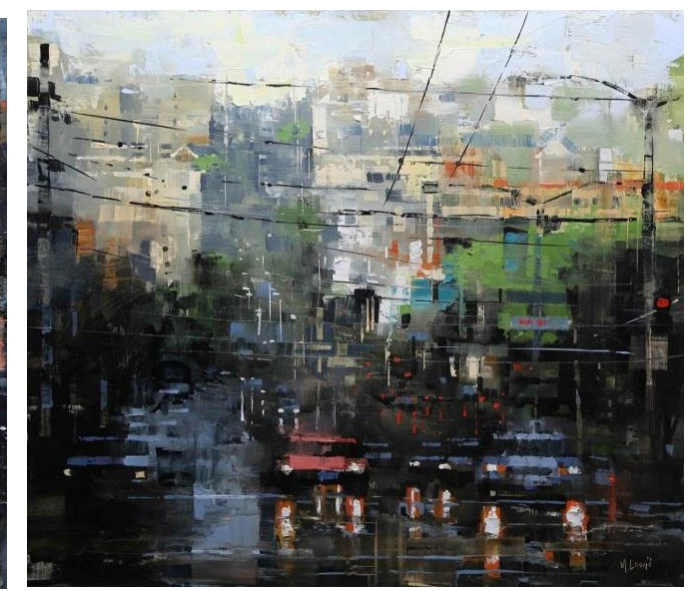

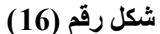

Lague

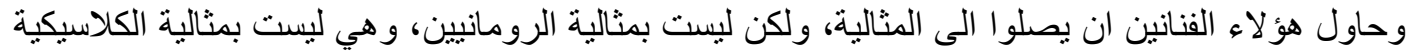

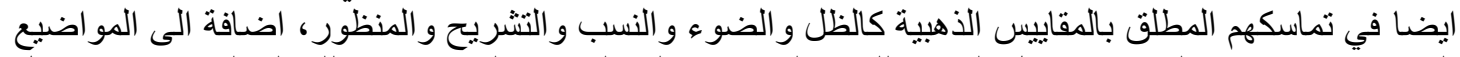

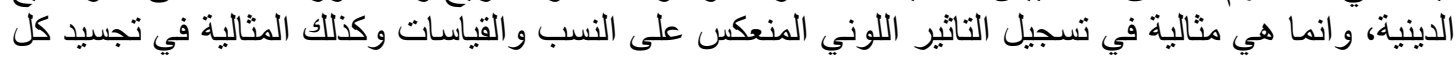

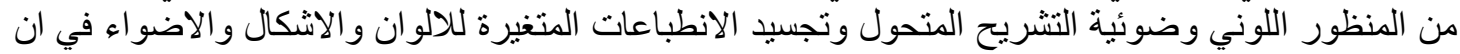

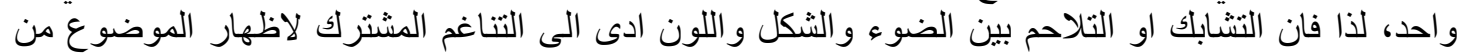

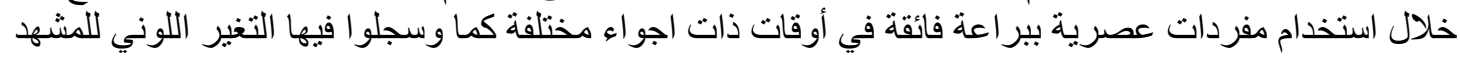

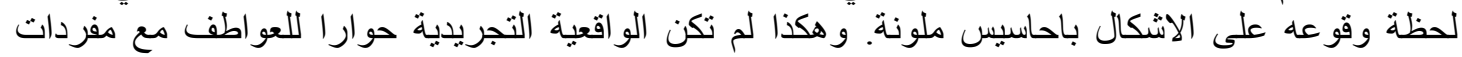

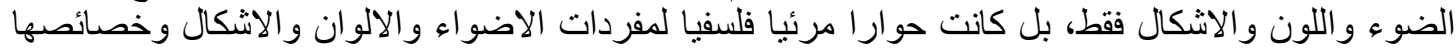
المرئية المحسوسة باتقان ودقة تامة.

مؤشرات الاطار النظري

بعد ان قام الباحث باستعر اض الاطنار النظري المتمثل في تقديم وتفصيل الجوانب الاساسية في البحث

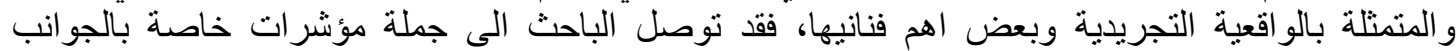

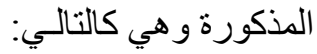

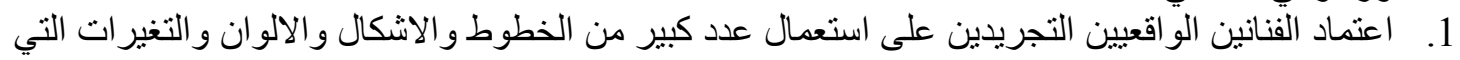

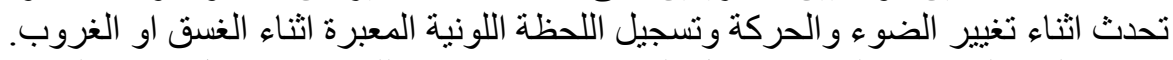

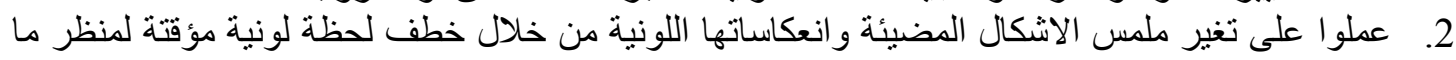

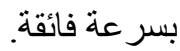

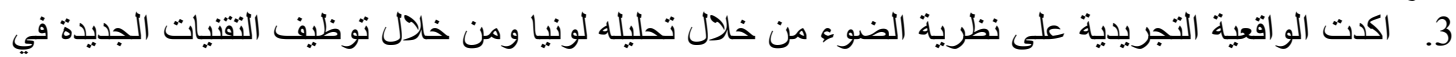
الرسم وهذا بذوره ادى الى تحقيق الاسلوب المتفرد لهذه النظرية والكثف عن الحقيقة الغير المرئية باسلوب تلابن

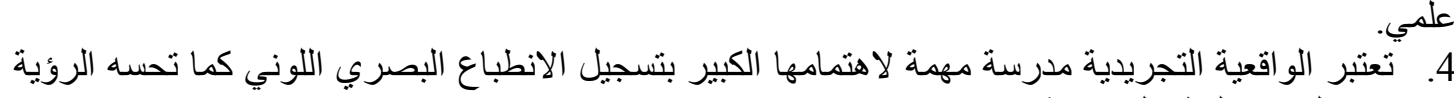

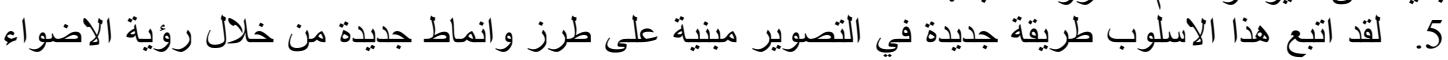

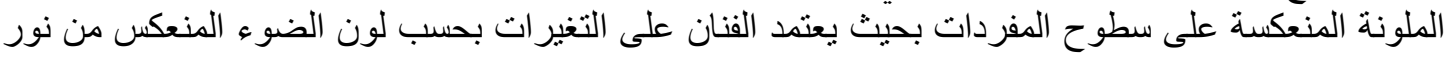

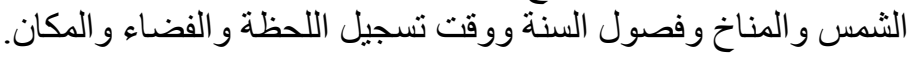
6. اهتمت هذه الددرسة باظهار الجانب الحسي للحركة اللونية من خلال الخطوط الحوط المختلفة الاتجاهات ذات

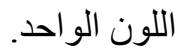




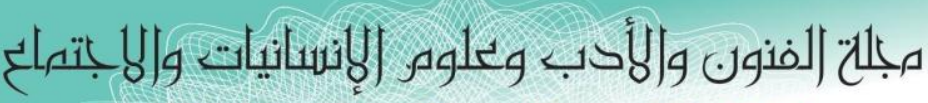
Journal of Arts, Literature, Humanities and Social Sciences

ISSN online: 2414 - 3383

ISSN print: 2616 - 3810

\section{9 نوفر Volume (45)}

العدد (45) November 2019

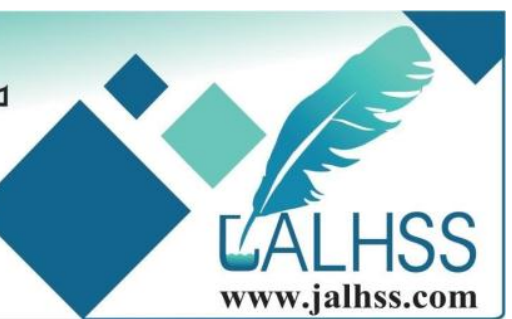

7. ت تميزت بوجود سيادة لونية و احدة كمسحة عامة على السطح التصويري.

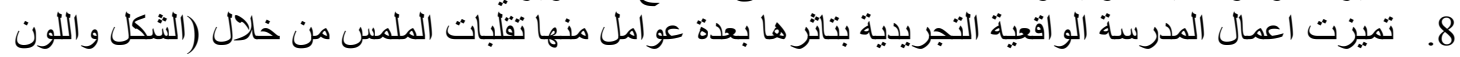
و الضوء) في اجو اء مناخية مختلفة. 9. لقد عنيت الو اقعية التجريدية بتسجيل الانطباع الكلي عن الاشياء، باسلوب او بطريقة ما بحيث بشعر

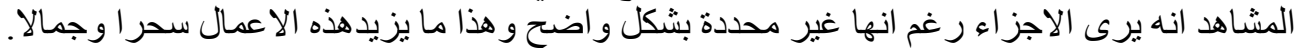

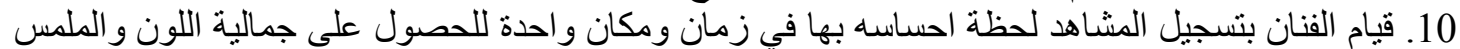
و الثكل معا. 11. اظهار لغة فلسفية محسوسة تعبر عن موجات ضوئية ملونة عابرة على سطح الاشكال.

\section{الفصل الثالث مجتمع البحث وعينته}

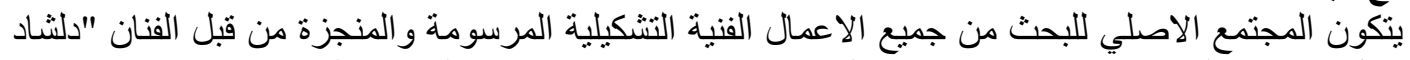

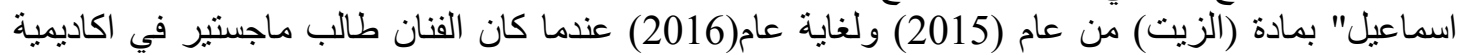
جامعة الفن، سان فر انسيسكو في الونام لايات المتحدة الامريكية.

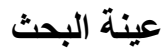

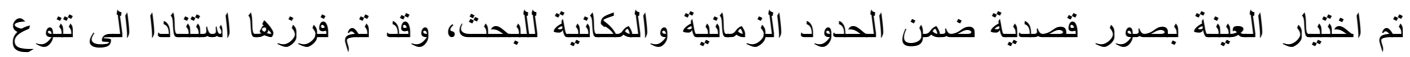

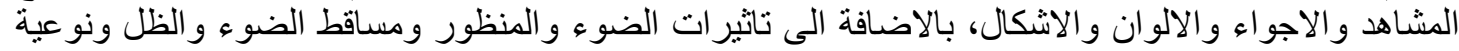
التقنية الفنية المستخدمة في تنفيذ العمل.

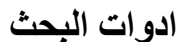

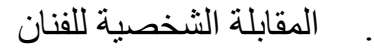

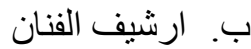
ج. الاعتادر المكتبية والوثائق المادية (اللوحات و الاعمال الفنية)

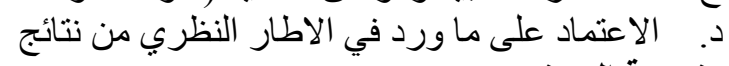
منهجية البحث اعتمد الباحث المنهج التحليلي الوصفي للاعمال الفنية ليتسنى تحقيق اهداف البحث.

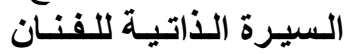
لقد ولد الفنان "دلثاد اسماعيل" في مدينة دهوك، مدينة الجمال و الجبال في اقليم كوردستـان سنة وانة 1979 من ابوين

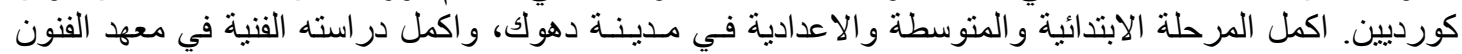

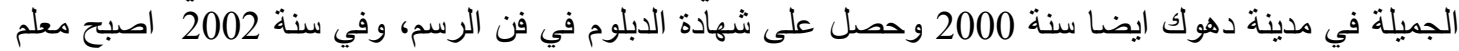

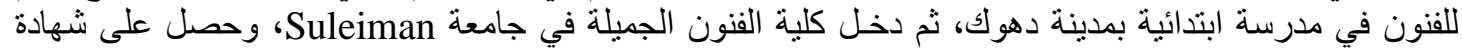

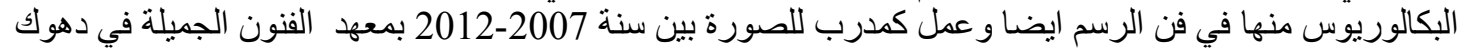

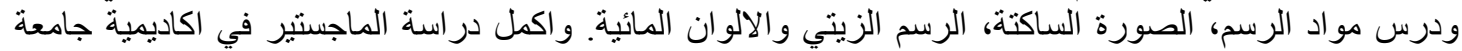

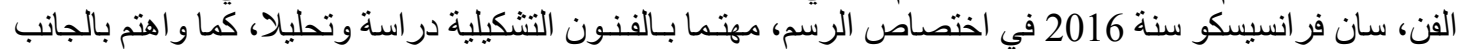
النظري و الجانب التطبيقي في ان واحد، وتميز بجر اته اللونية واسلوب لوحاته النئه المتميز. 


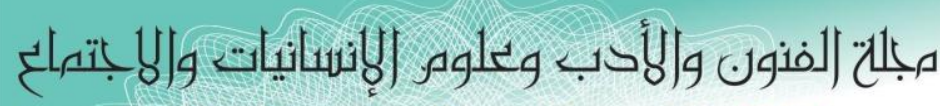
Journal of Arts, Literature, Humanities and Social Sciences

ISSN online: 2414 - 3383

ISSN print: 2616 - 3810

\section{9 نوفر Volume (45)}

العدد (45) November 2019

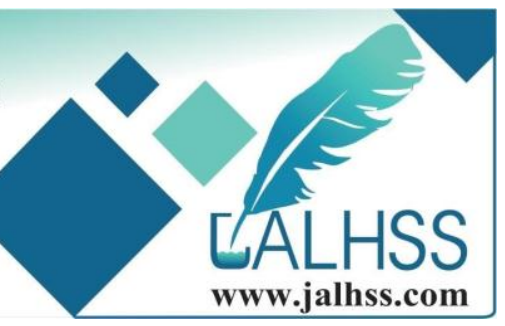

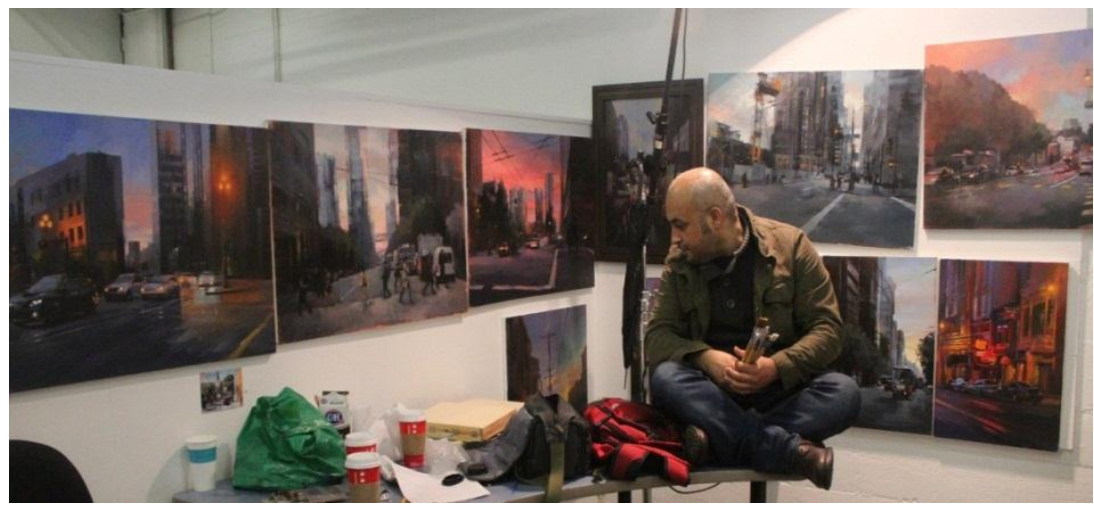

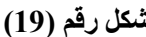

مرسم الفنان "دلثناد اسماعيل"،2015، سان فرانسيسكو

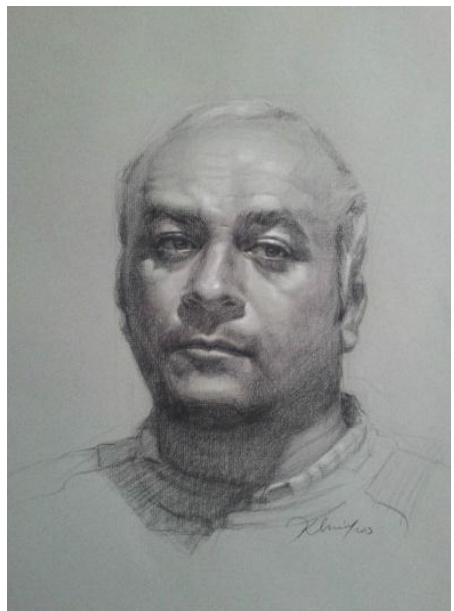

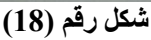

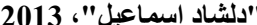
تخطيط الفنان - خيري آدم

المشاركات الفتية

أ. حصل على جائزة اثناء مشاركته في معرض اقامته في حكومة اقليم كوردستان العراق، مجلس الوزراء، وزارة التعليم العالي و البحث العلمي سنة 2012. ب. مشاركته في سنة 2015 في معرض الربيع في اكاديمية جامعة الفن سان فر انسيسكو.

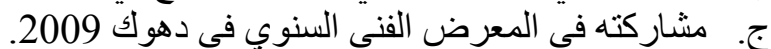

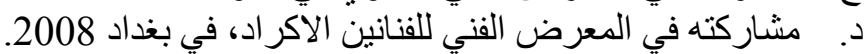

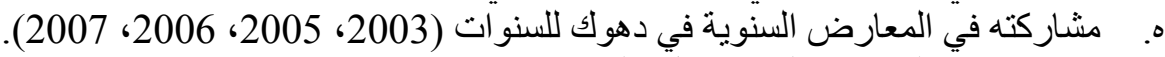

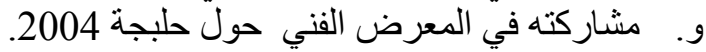

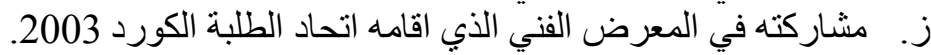
ح. مشاركته في المعرض الفني حول الابادة الجماعية للثعب الكوردي في كلية كلية الفنون الجميلة، Suleiman كردستان 2005.

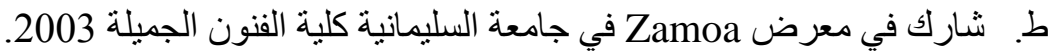
ي. مشاركة في المعرض السنوي، كليَّة الفنون الجميلةِ ،السليمانية سنة 2001 ـ

التجارب الفنية والاسلوب الفني للقنان دلثاد اسماعيل

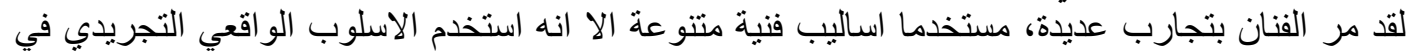

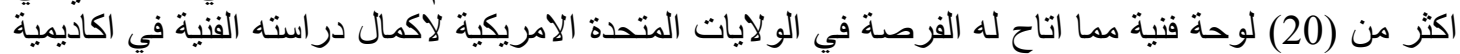

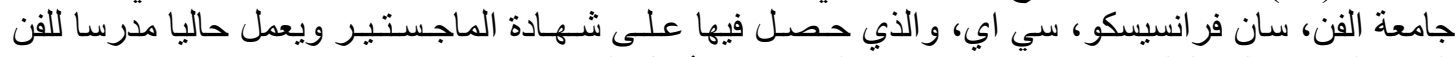

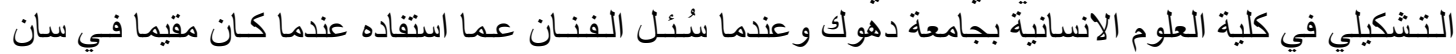

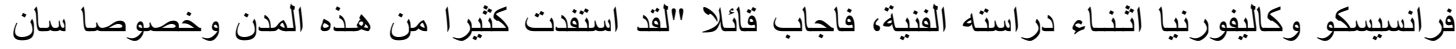

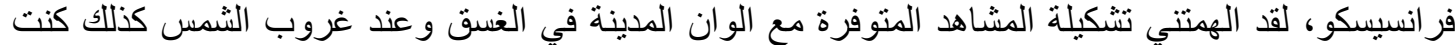

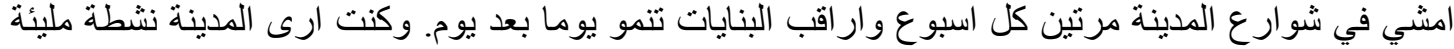

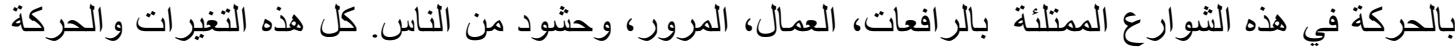

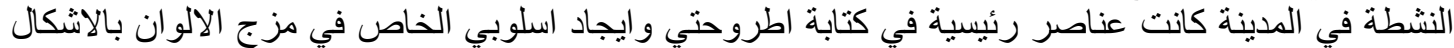

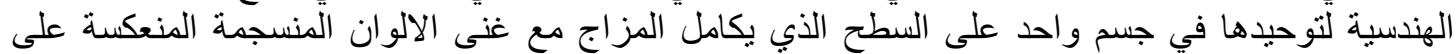
البنايات في الغسق والغروب) وقال ايضا: "ان اللحظات المعبرة تسندعى الاحساس بالجمال الهادئ وتمنح 


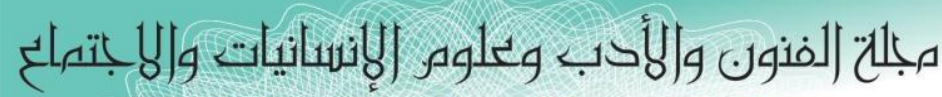
Journal of Arts, Literature, Humanities and Social Sciences

\begin{tabular}{lcc|} 
ISSN online: $2414-3383$ & $\begin{array}{l}2019 \\
\text { Volume (45) }\end{array}$ \\
ISSN print: $2616-3810$ & $\begin{array}{c}\text { (45) } \\
\text { November } 2019\end{array}$
\end{tabular}

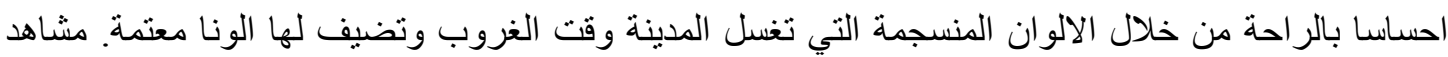

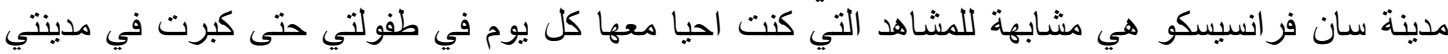

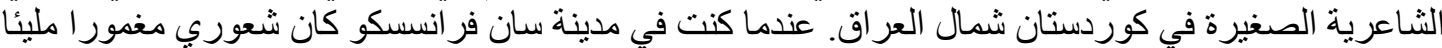

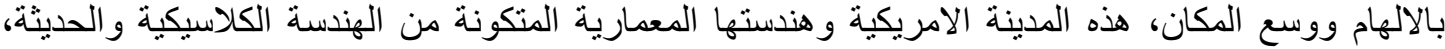

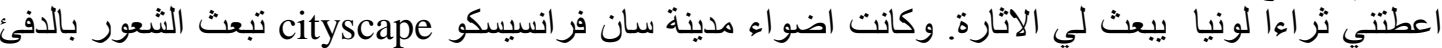

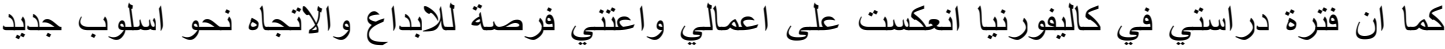

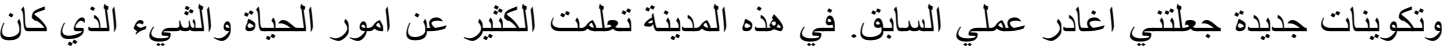

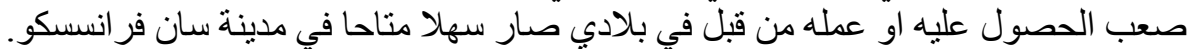

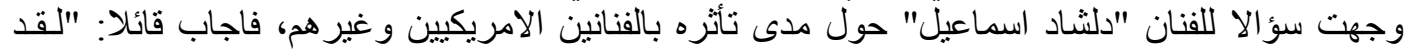

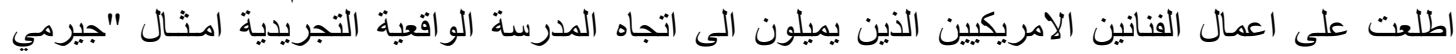

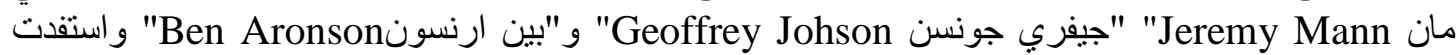

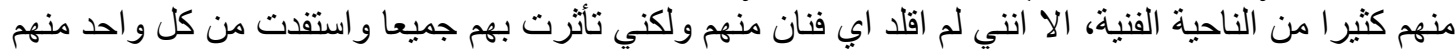

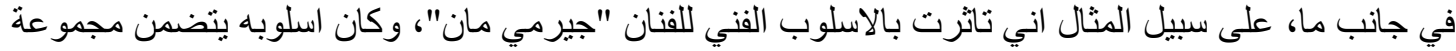

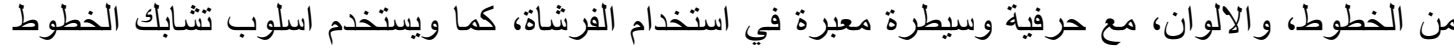

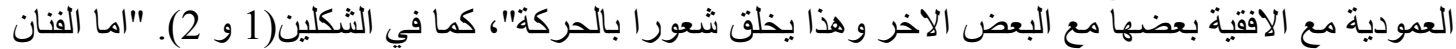

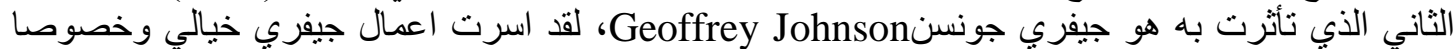

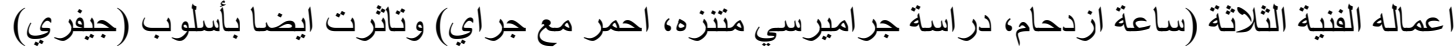

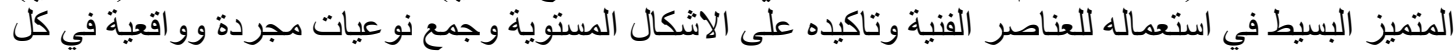

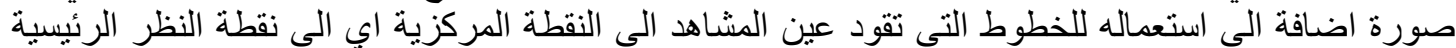

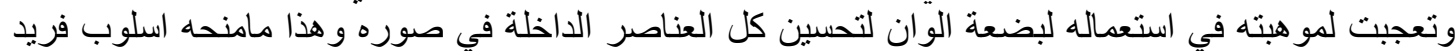
يميزه عن الاخرين" كما في الاشكال (21،20،22).

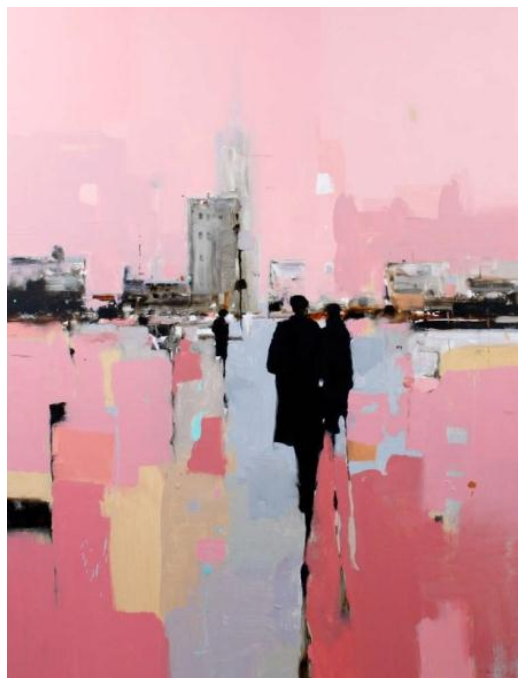

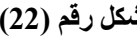
"احمر مع جراي"، نفط على لخنة

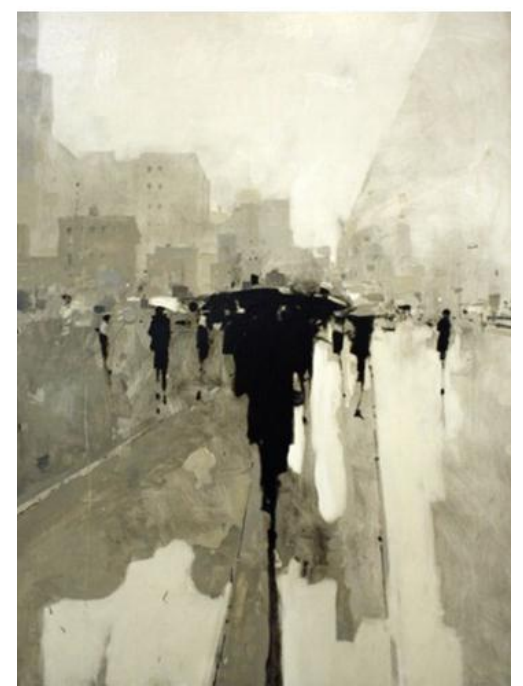

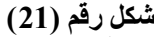

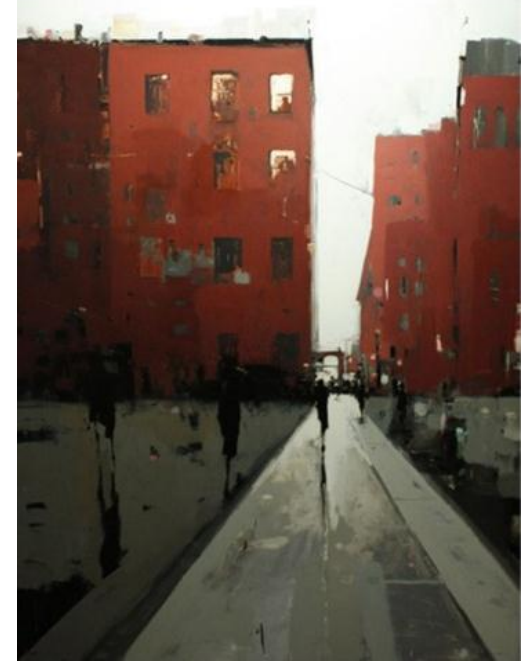

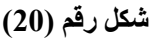

دراسة جراميرسي متنزه"،نفط على خشب،2015 "ساعة ازدحام"، نفط على جنفاص،2015 خشب،2015

ويضيف ايضا: "اما الفنان الثالث الذي نأثرت به هو (بين ارو نسون) Ben Aronson ، فقد احبيت صوره

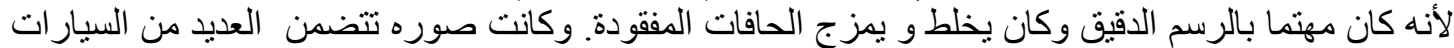

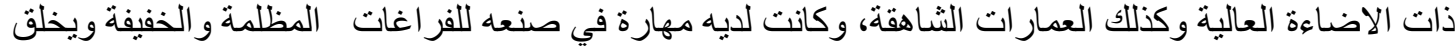

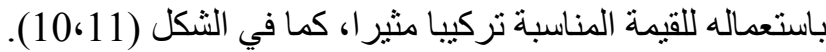


مبلحت (لفنون والأدب وعلوه الإنسانيات و|لهابتهالغ Journal of Arts, Literature, Humanities and Social Sciences

ISSN online: 2414 - 3383

ISSN print: 2616 - 3810

\section{9 نوفر \\ Volume (45)}

(45) (40)

November 2019

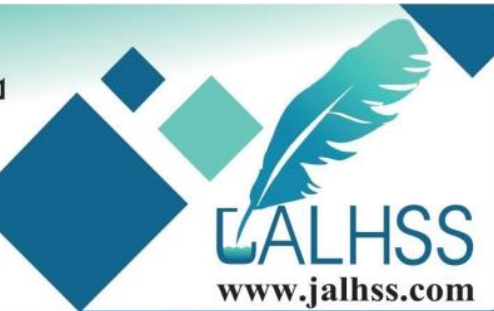

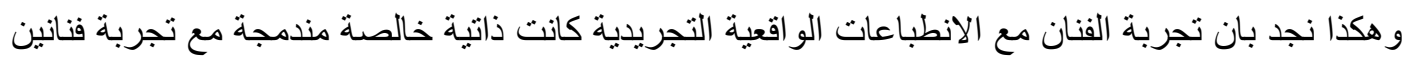

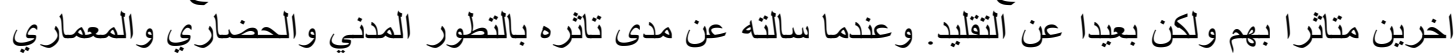

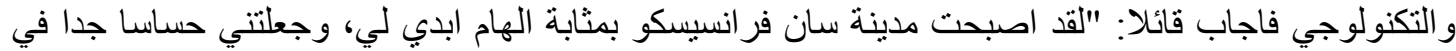

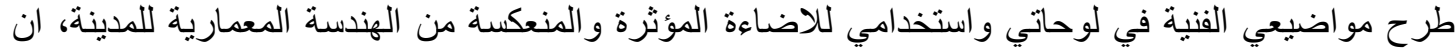

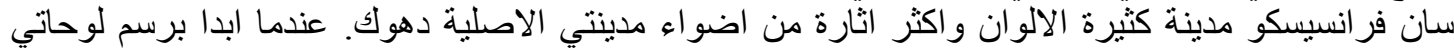

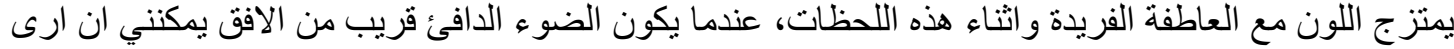

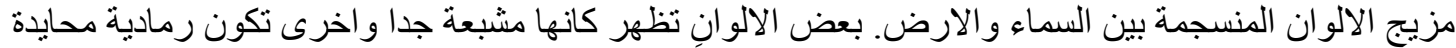

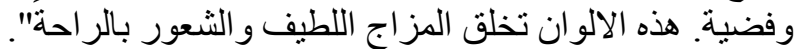

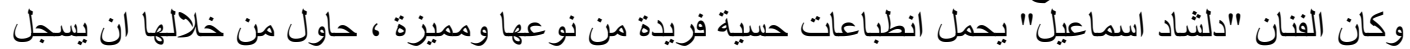

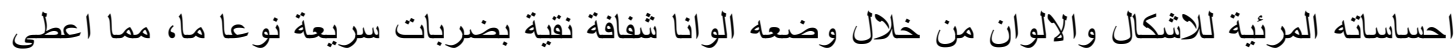

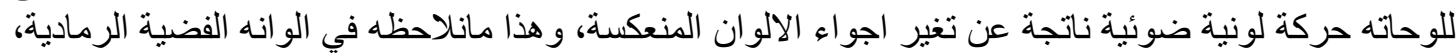

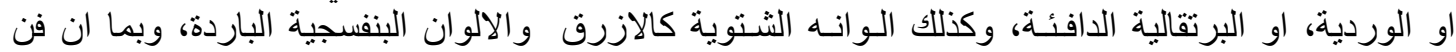

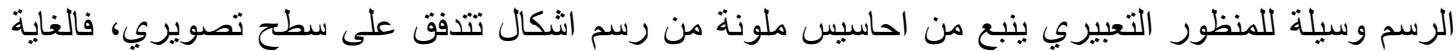

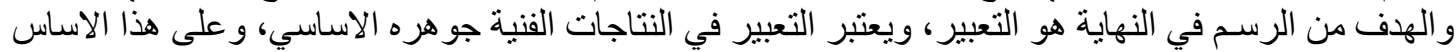

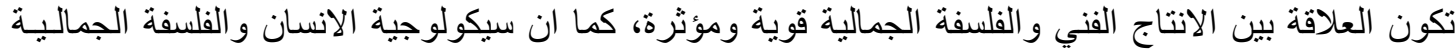

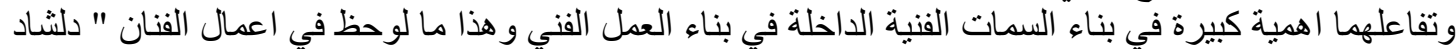
اسماعيل" وفي صحة اختياره للمدرسة الفنية التي تعبر عن ذاتها. الفئ.

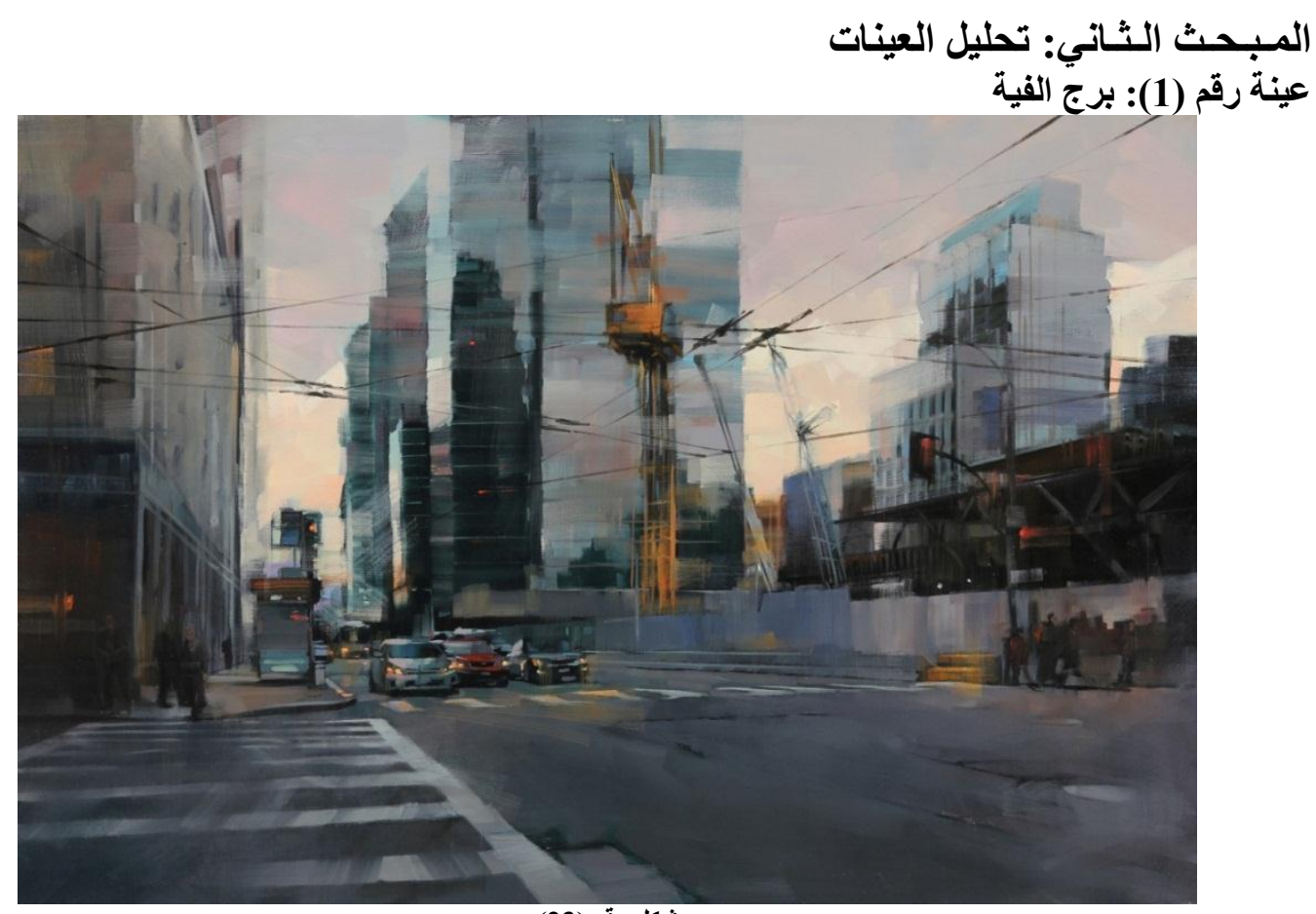

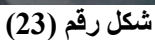

دلثاد اسماعيل "برج الفية" (24×36)، زيت على جنفاص، 2015، ارشيف الفنان

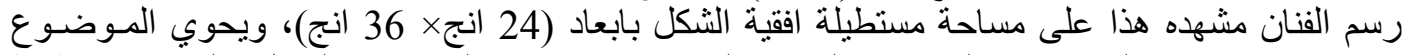

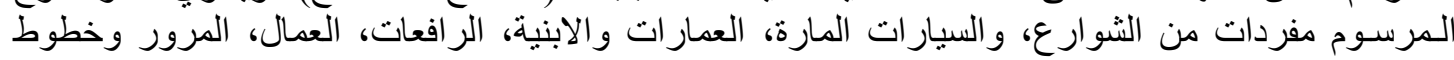

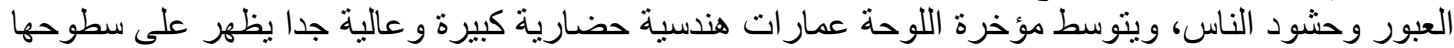

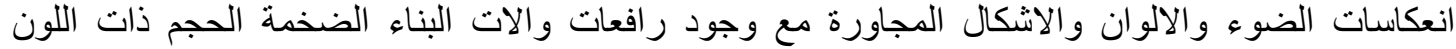




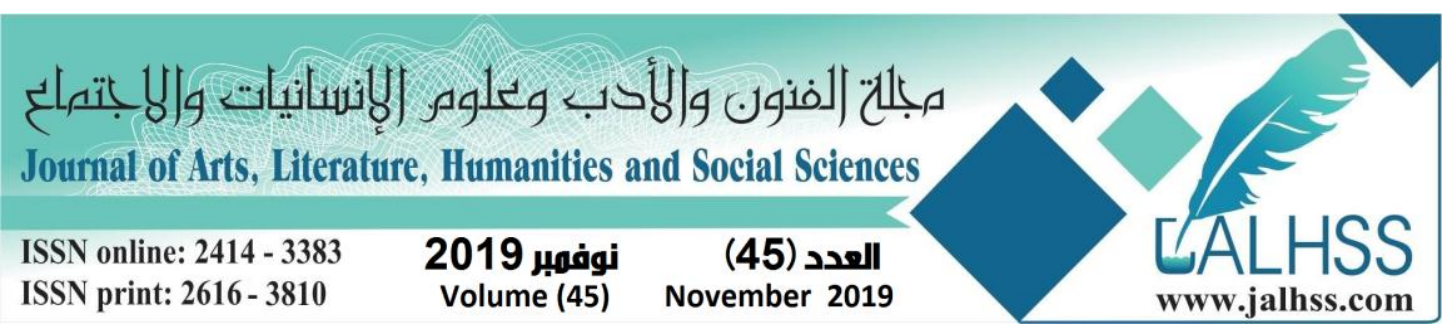

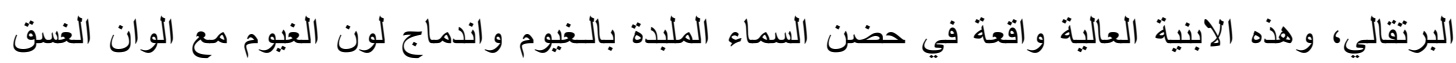

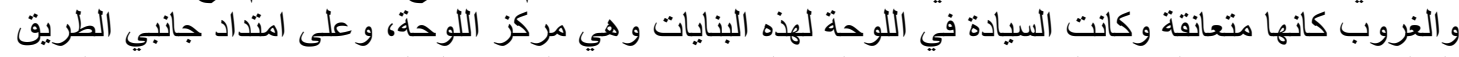

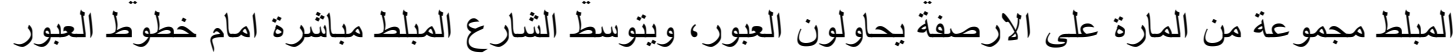

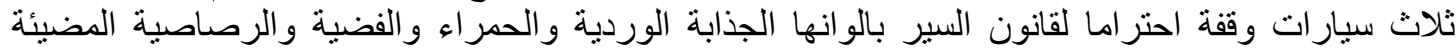

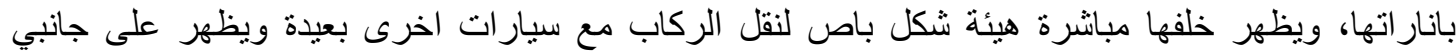

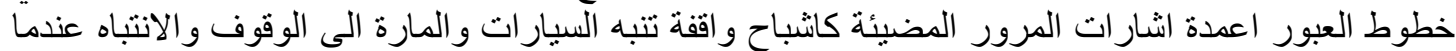

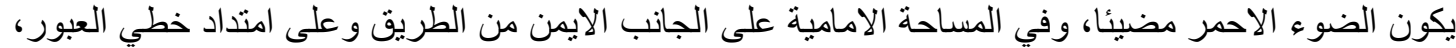

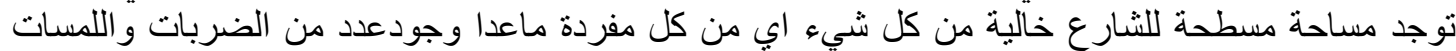

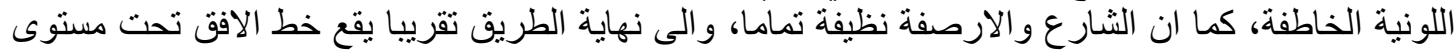

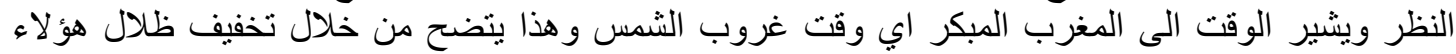

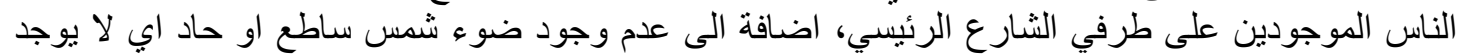

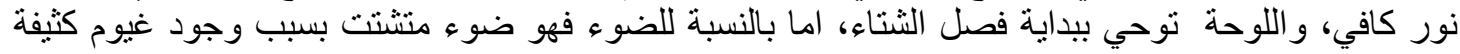

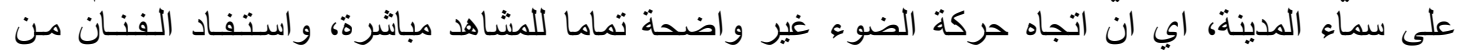

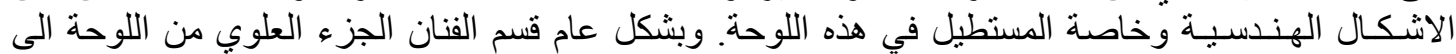

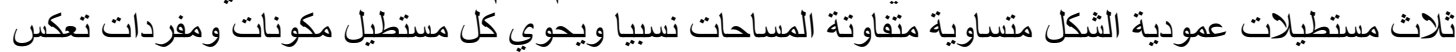
الاجو اء ويحوي كل مستطيل نسبة من الضوء

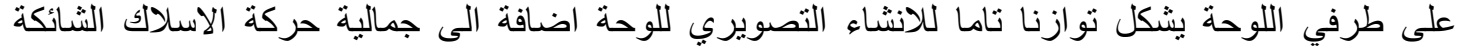

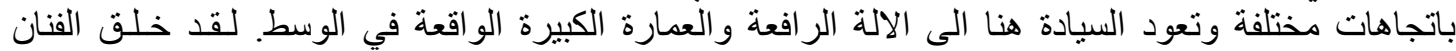

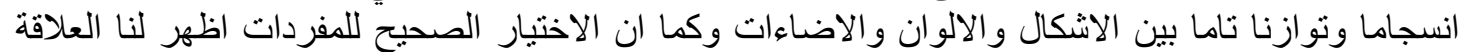

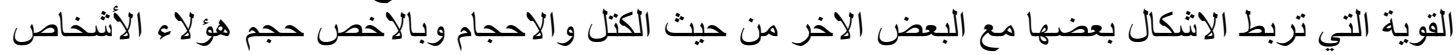

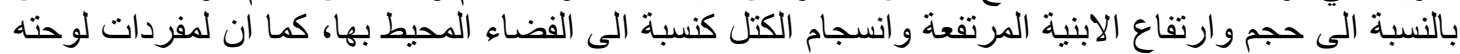

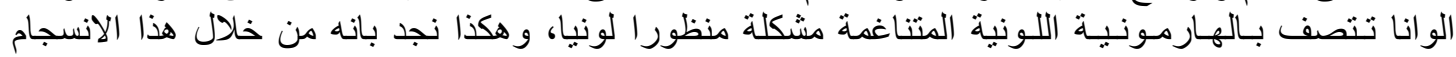

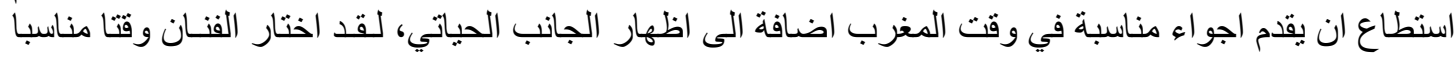

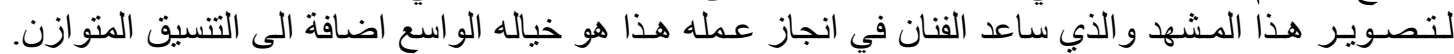

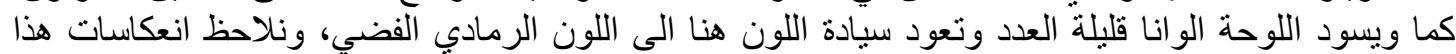

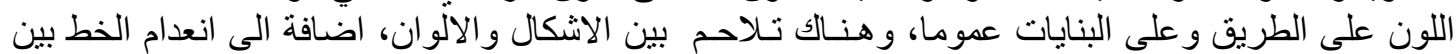

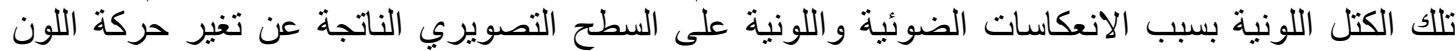

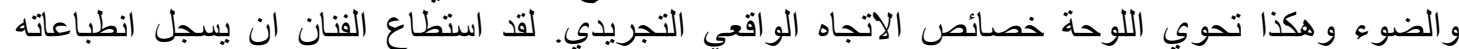

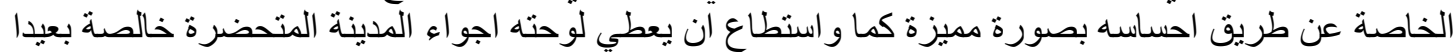

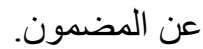



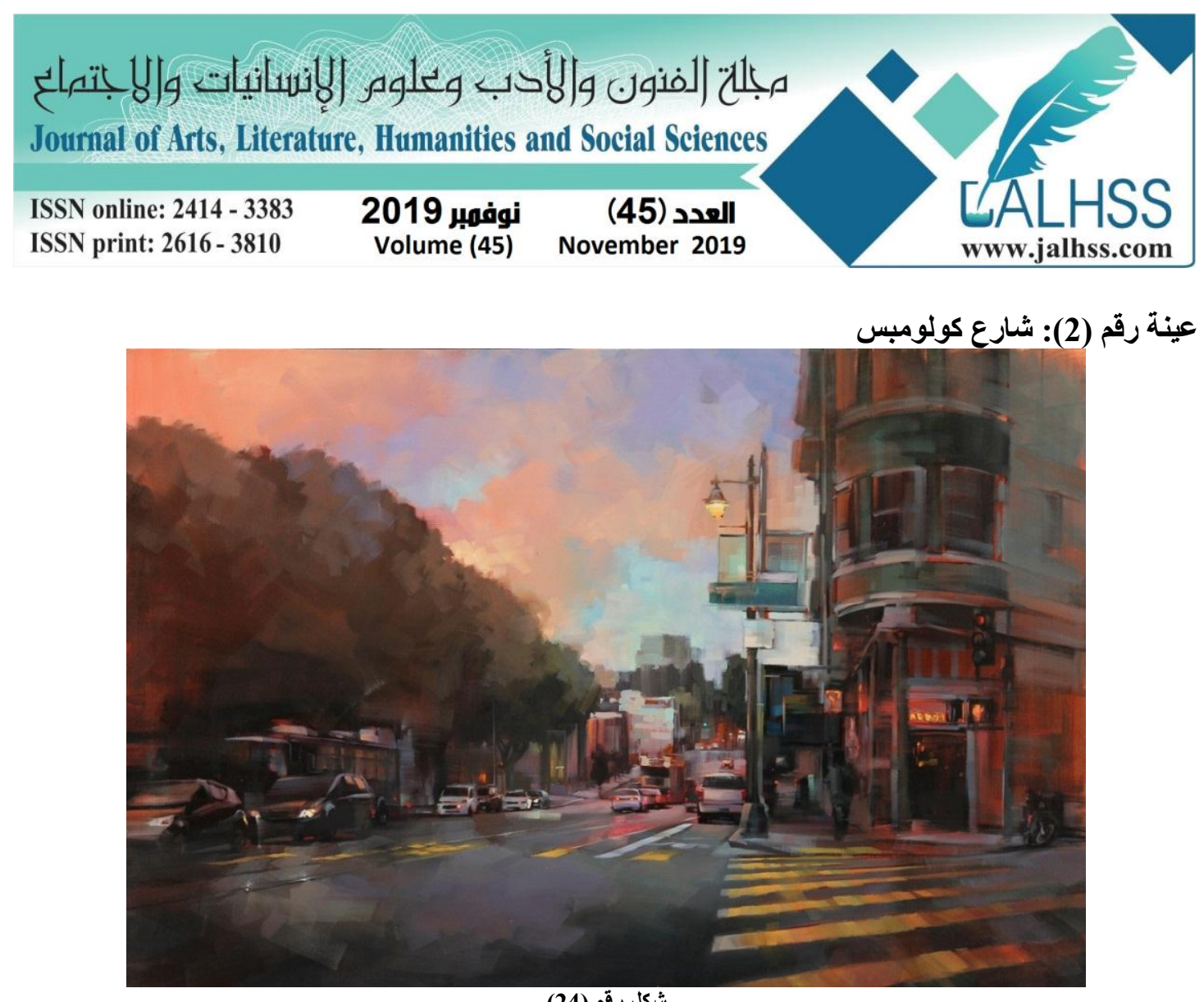

شكل رقم (24) (24)

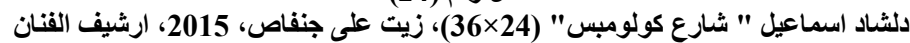

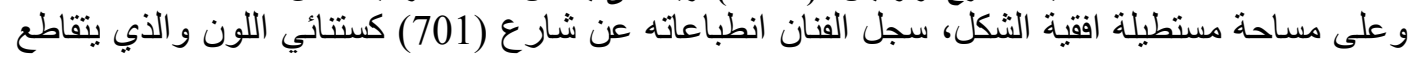

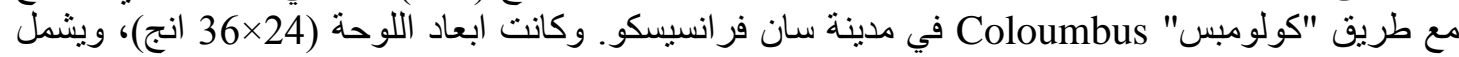
الموضوع، طبيعة مع تقاطع الالوان وتداخلها خالصة، اي ان لنومان هناك تداخلا بين الالوان المكملة البرتقالية

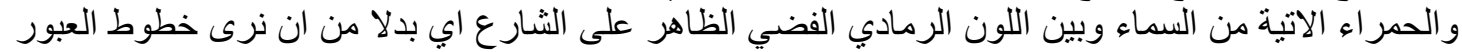

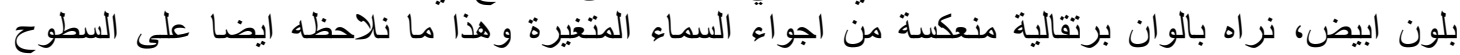

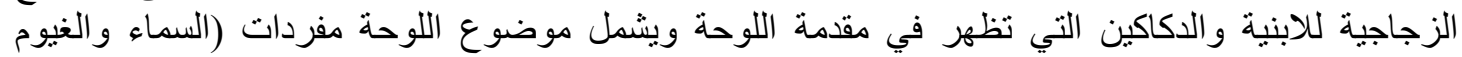

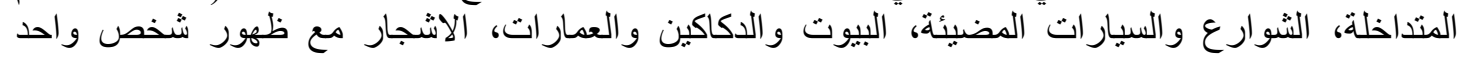

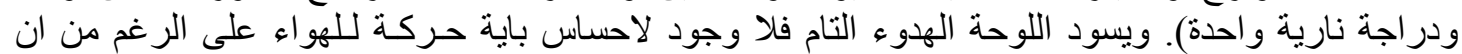

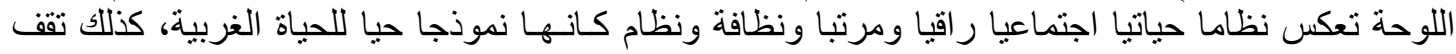

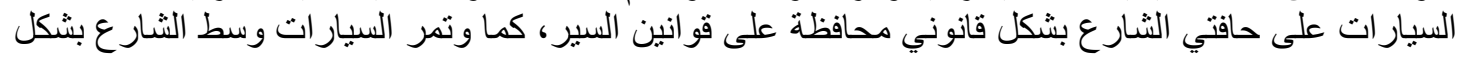

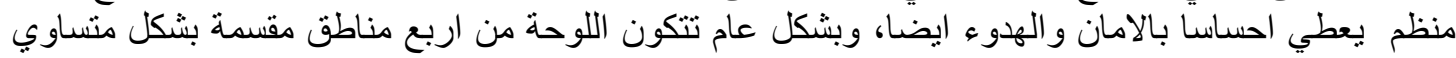

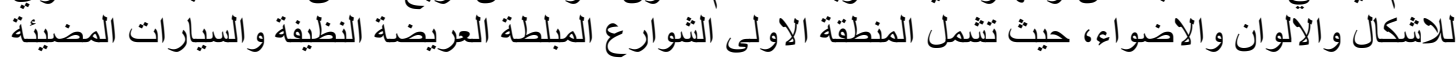

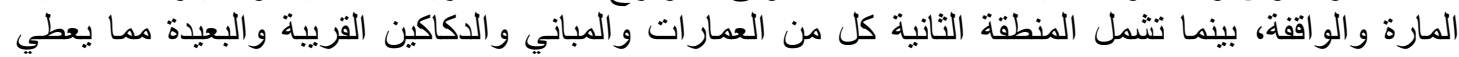

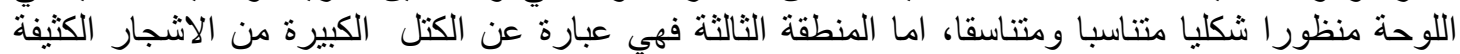

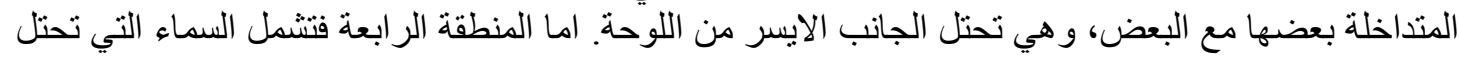

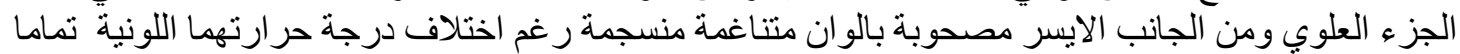

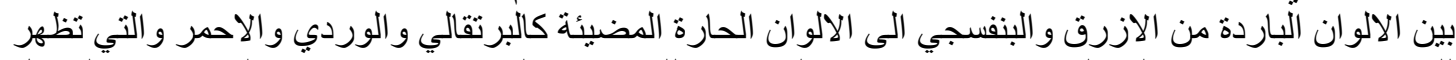

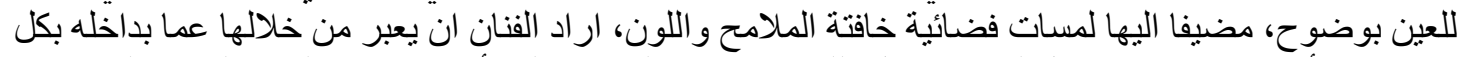

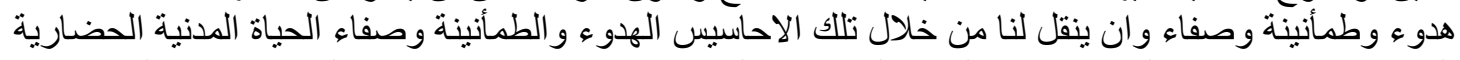

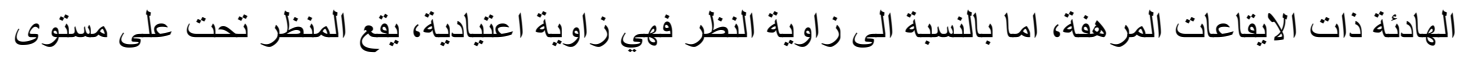

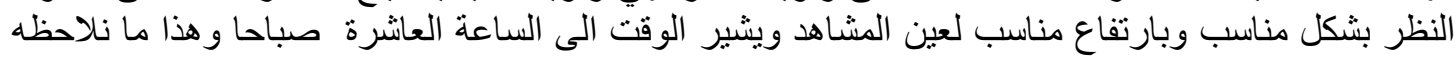

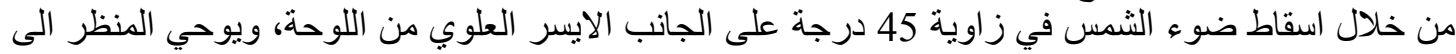

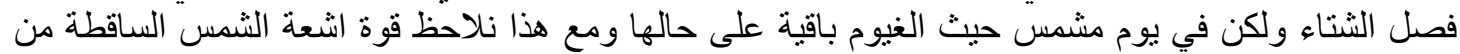
خلال ظلالها البرتقالية اللون على الارض والذي شكل تناقضا واضحا بين الظل والضوء. ورسم الفنان لوحته 


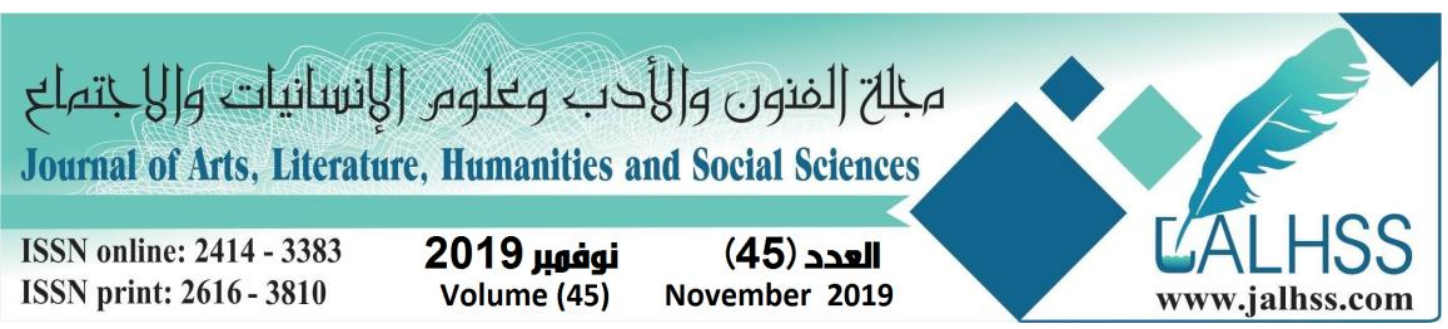

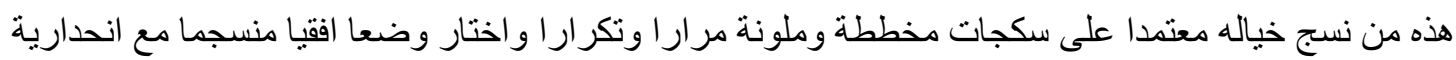

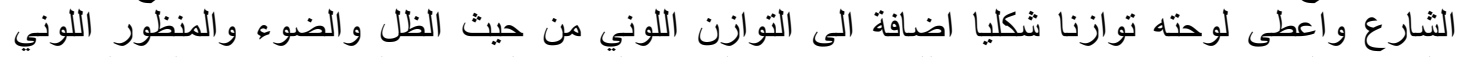

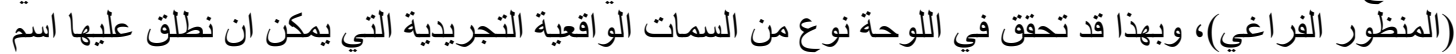

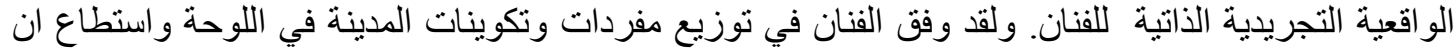

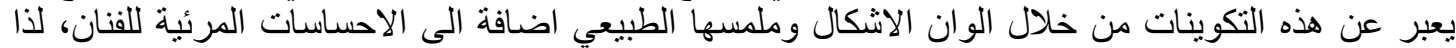

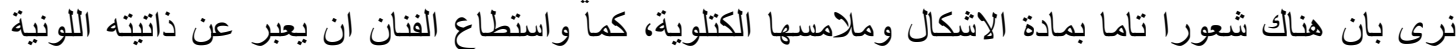

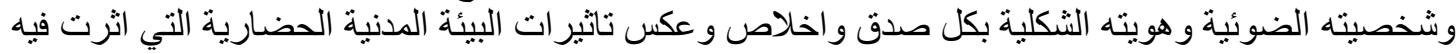

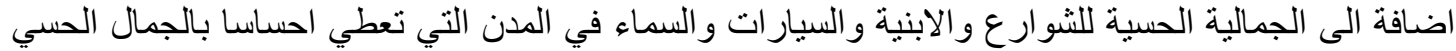

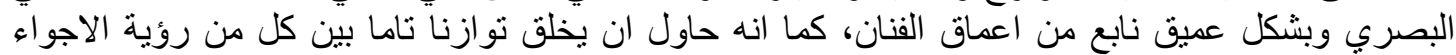

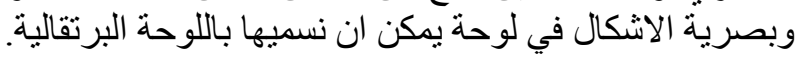

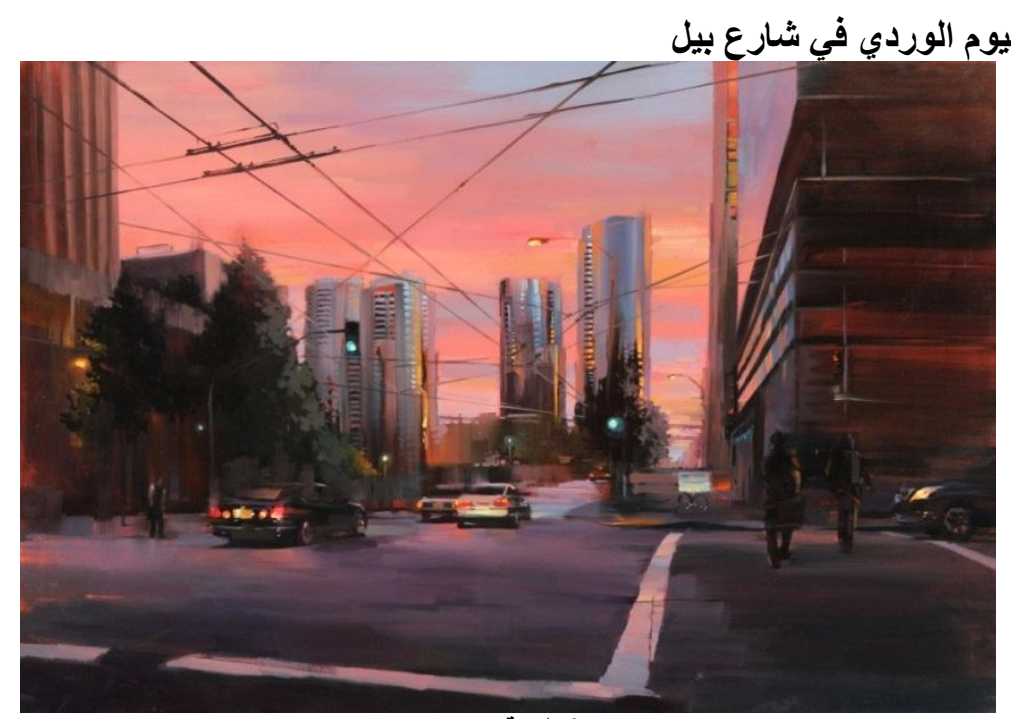

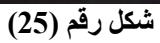

دلثاد اسماعيل "اليوم الوردي في شارع بيل" (24×36 (36)، زيت على جنفاص، 2015، ارشيف الفنان

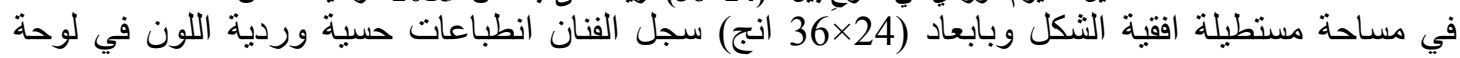

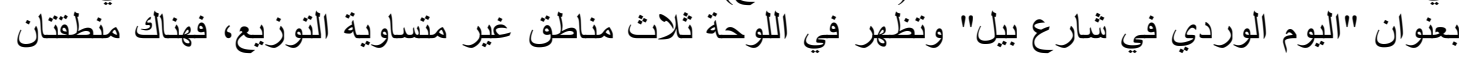

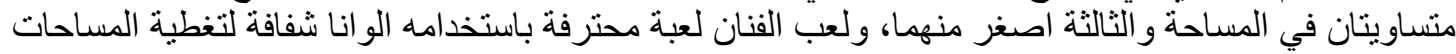

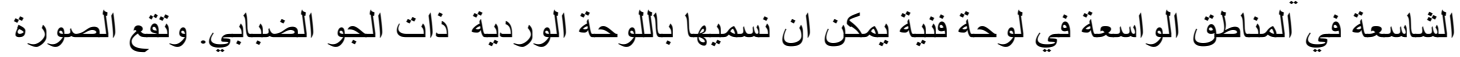

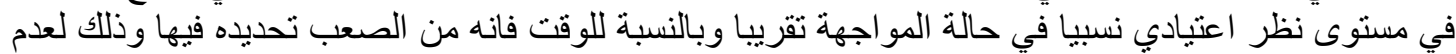

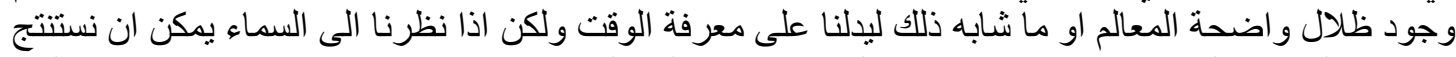

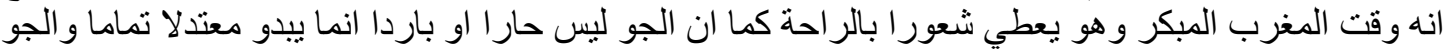

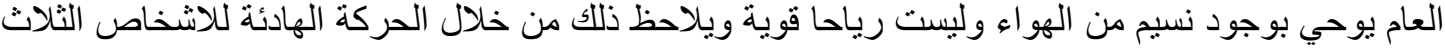

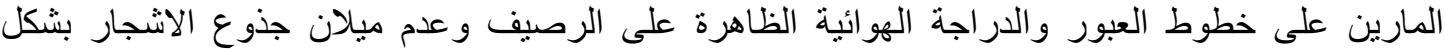

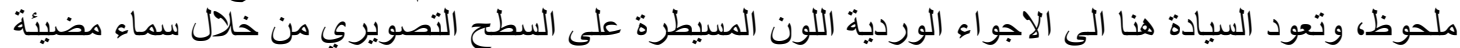

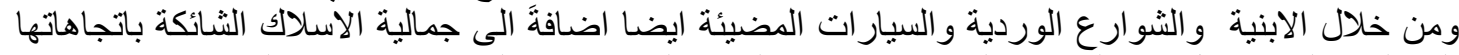

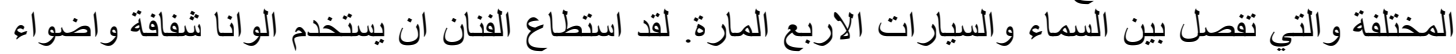

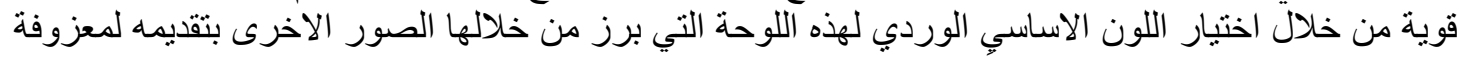

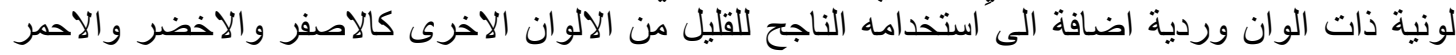

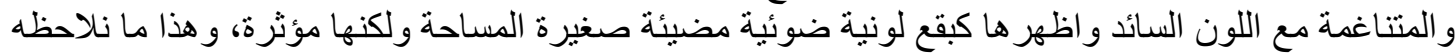

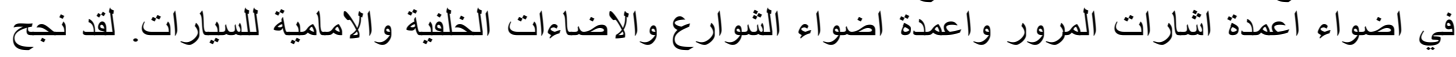




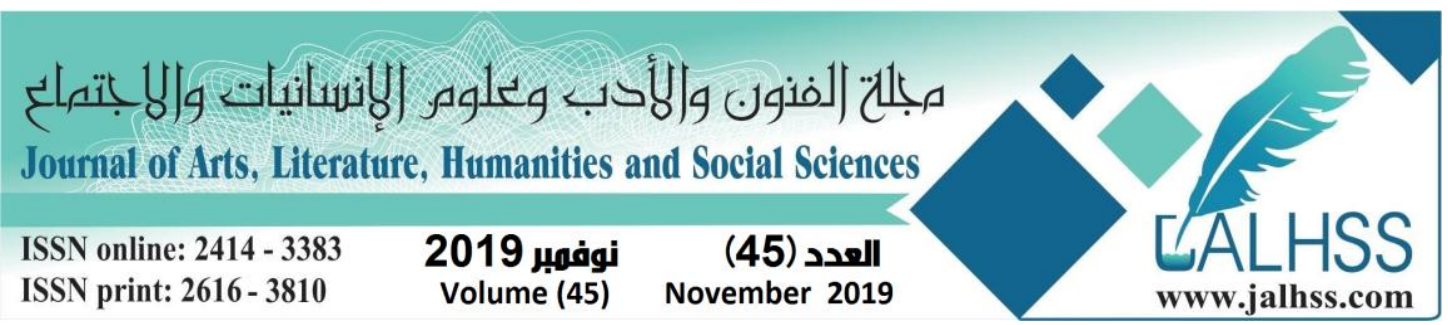

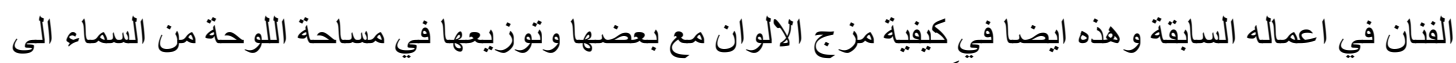

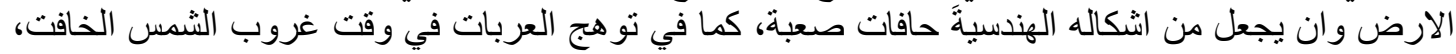
و هدف الفنان في هذه اللوحة تحسين المزاج العام للصورة باختياره اللون الورن الوردي كاساس لبناياتها من حيث

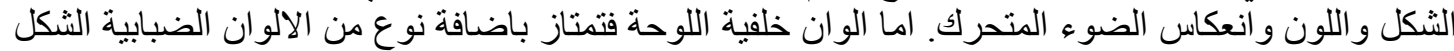

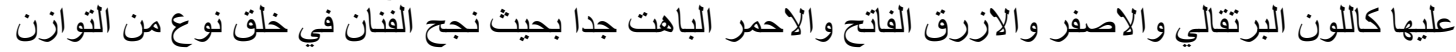

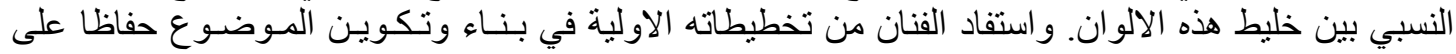

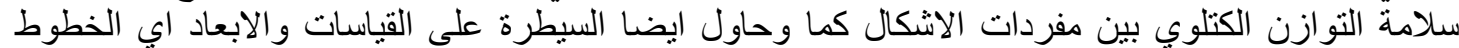

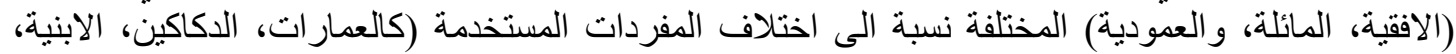

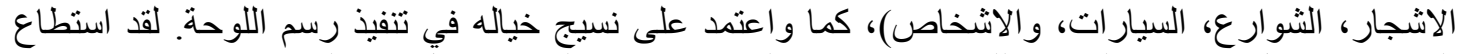

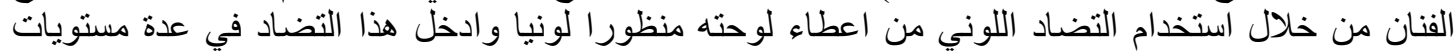

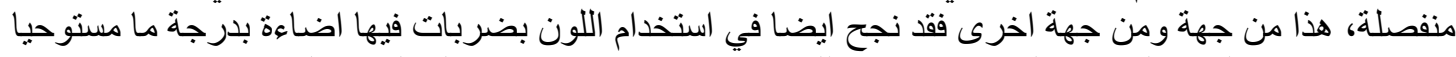

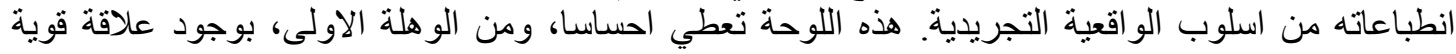

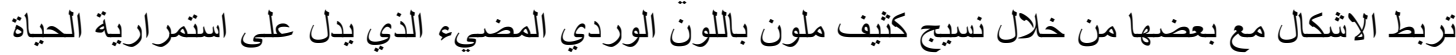

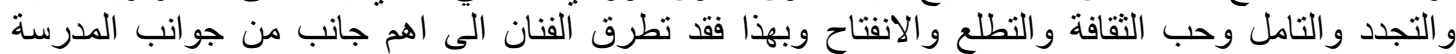
الو اقعية التجريدية فهو جعل من الثكل و المضمون في ميز ان متو ازن الثقل ولكن بانطباعات حسية ضونئية شكلية مر هفة في مشهر وردي.

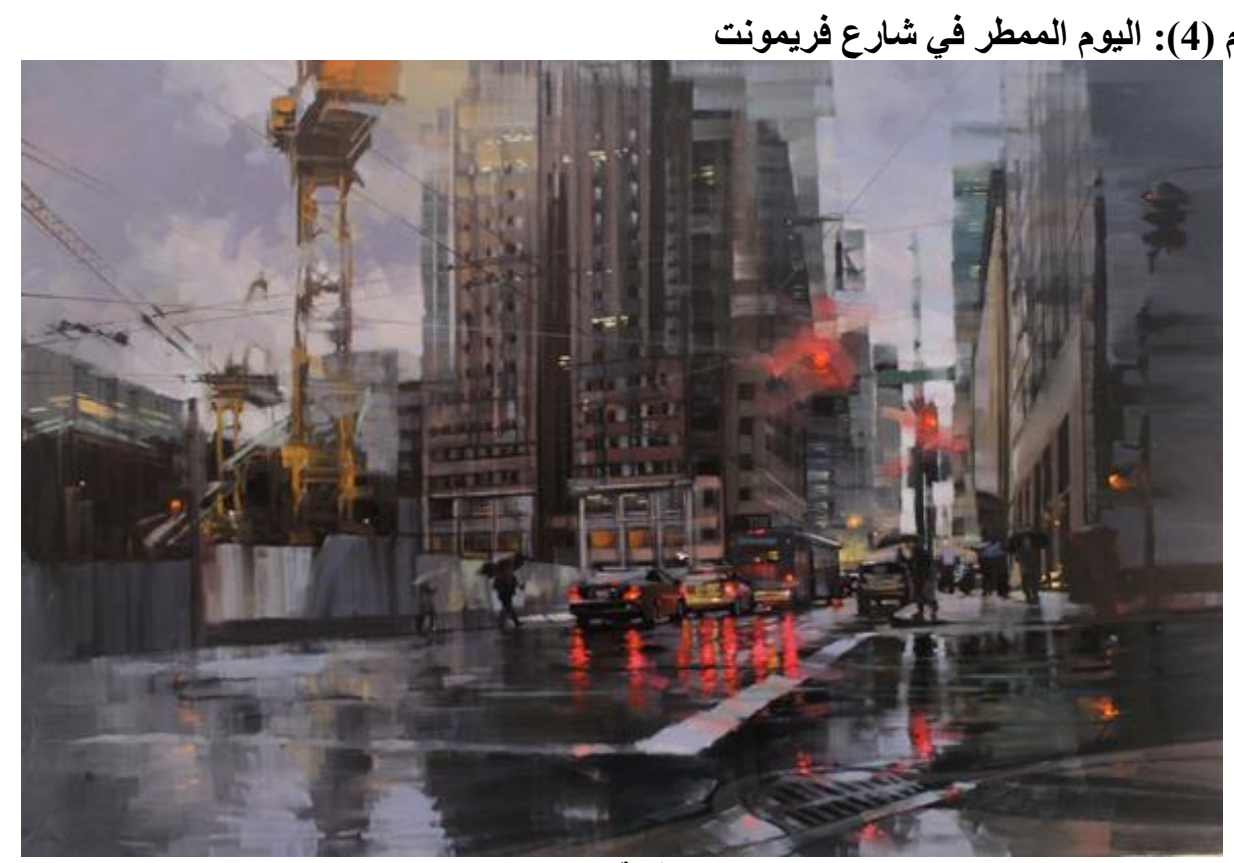

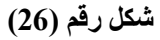

دلثاد اسماعيل "اليوم الممطر في شارع فريمونت"، (24×36 (26)، زيت على جنفاص، 2016، ارشيف الفنان

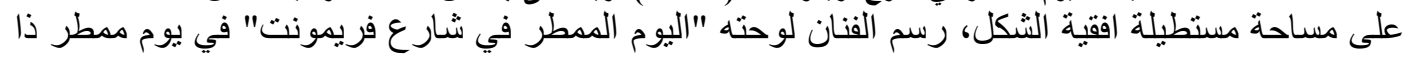

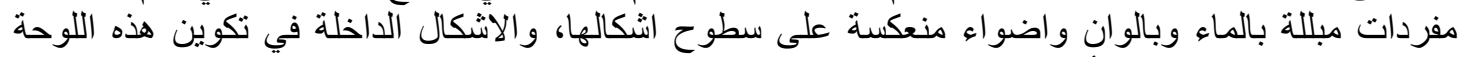

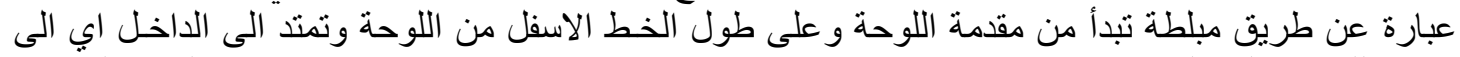
عمق اللوحة على الجانبين الايمن والايسر ولا تظان تظهر نهايته بسبب وجود حشد من مركبات السير المضيئة

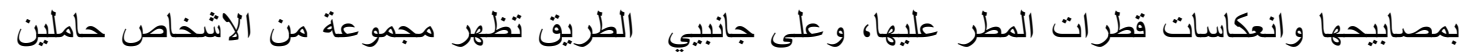

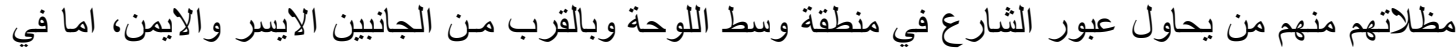
الجانب الايــن مـن اللوحة فهناك الحائط المستطيل الثكل والذي هو واجهة العمار ات في حالة المنظور وعليه 


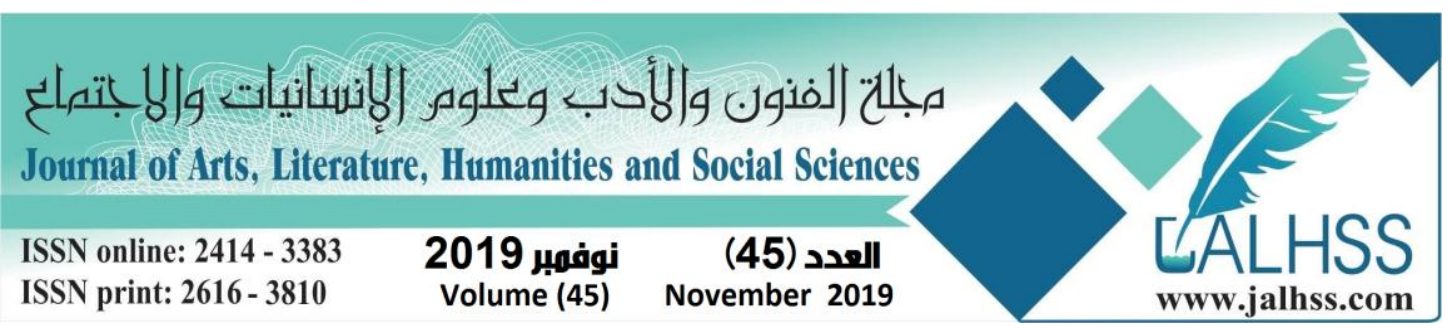

تظهر انعكاسات لونية وضوئية تعكس الاشكال المحيط به، وتظهر مباشرة مقابله اي على الجانب الايسر

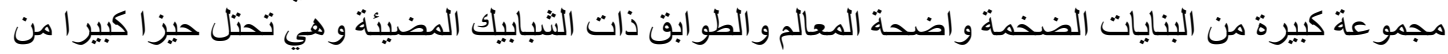

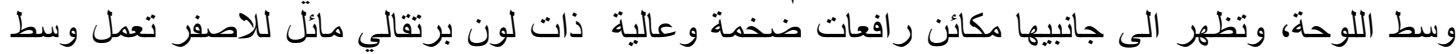

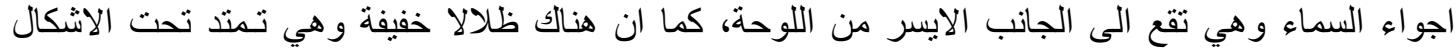
مباشرة كي يقول لنا بان الوقت هو منتصف النهار تقريبا وتكون الضلاءل عادة في هذه الاوقات خفيفة تظهر

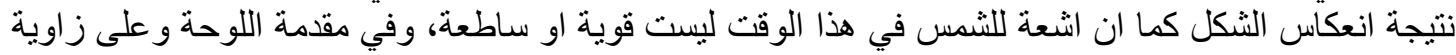

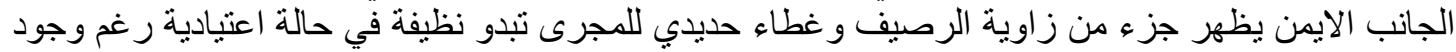

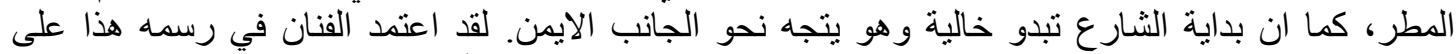

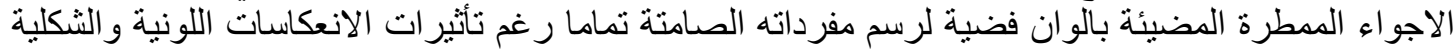
والضوئية الناتجة عن مياه الامطار الساقطة على سطوح نلك الأثكال التي جعلتها متذبذبة ومتحركة ضونئيا

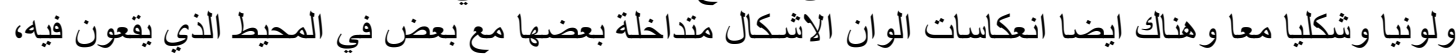

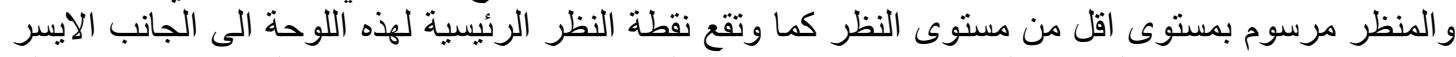

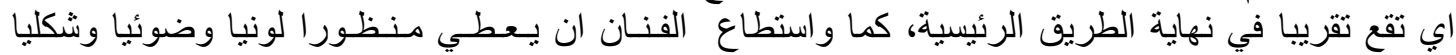

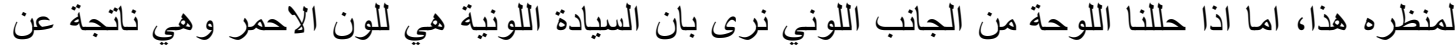

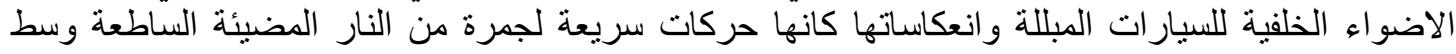

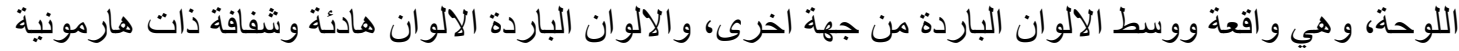

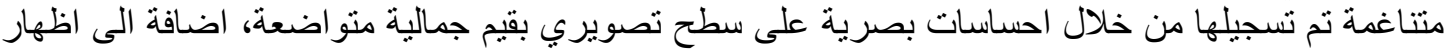
اثار الاضواء المبللة من ضربات فنية للفرش كصفة تقنية وجمالية في ان و احد، وبهذا طبق الفنان انطباعات

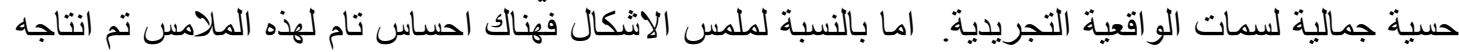

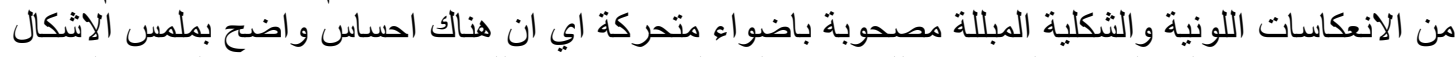

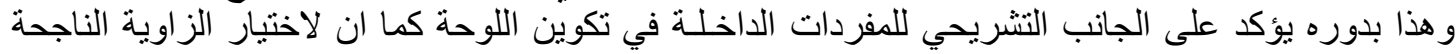

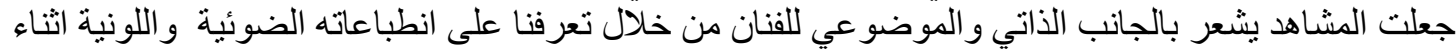

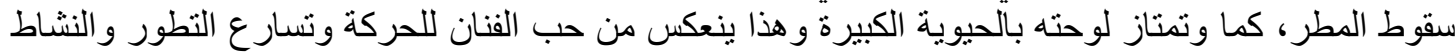

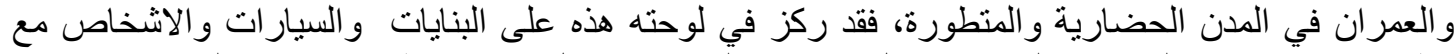

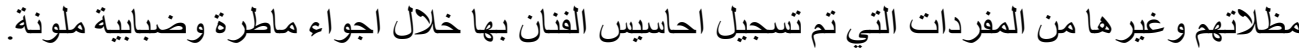

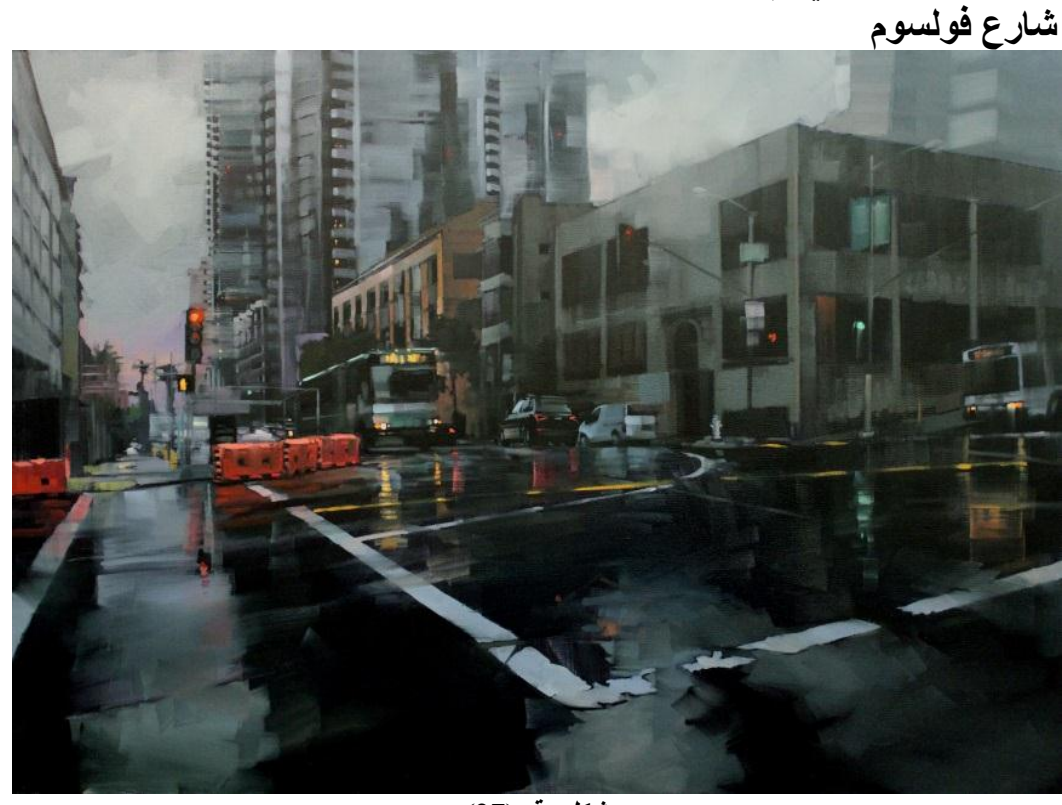

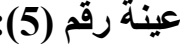

شكل رقم (27)

دلثاد اسماعيل "شارع فولسوم" (24×36)، زيت على جنفاص، 2016، ارشيف الفنان 


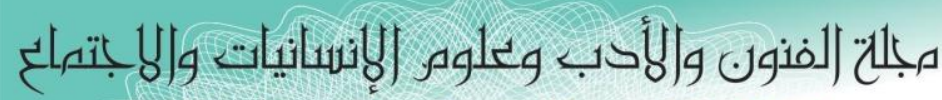
Journal of Arts, Literature, Humanities and Social Sciences

ISSN online: 2414 - 3383

ISSN print: 2616 - 3810

\section{9 نوفر Volume (45)}

(45) (40) November 2019

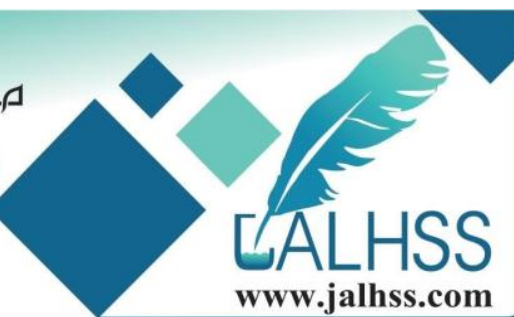

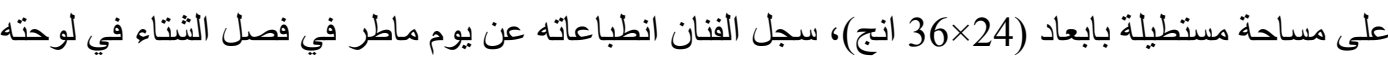

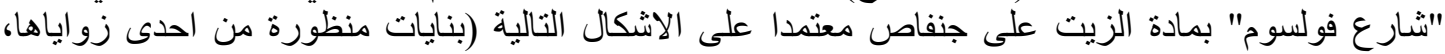

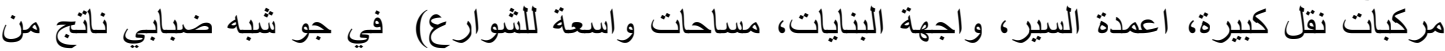

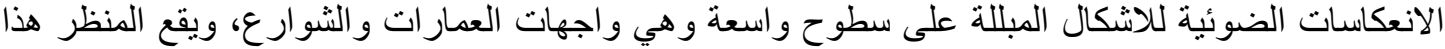

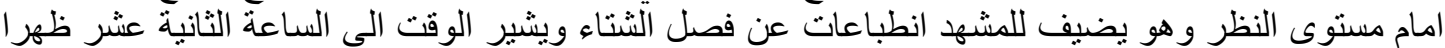

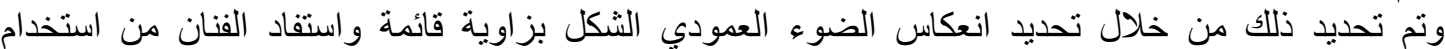

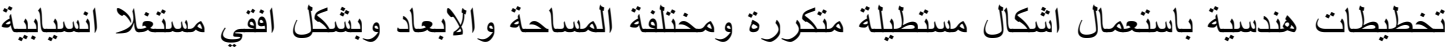

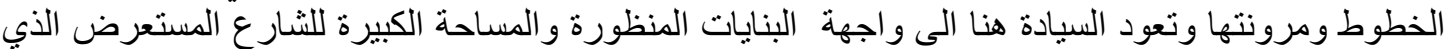

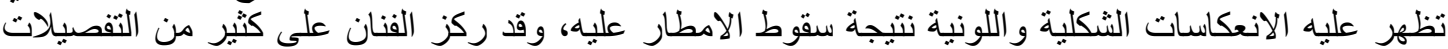

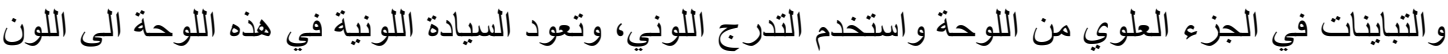

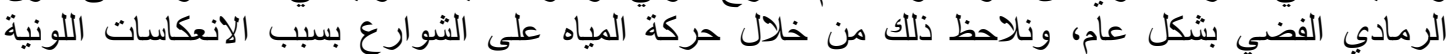

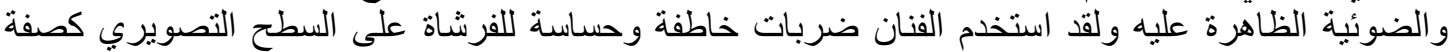

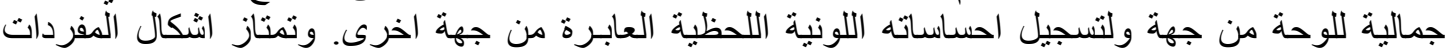

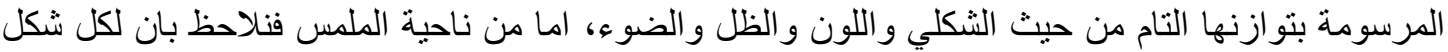

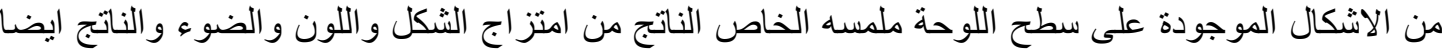
من انعكاسات قطر ات المطر المضيئة.

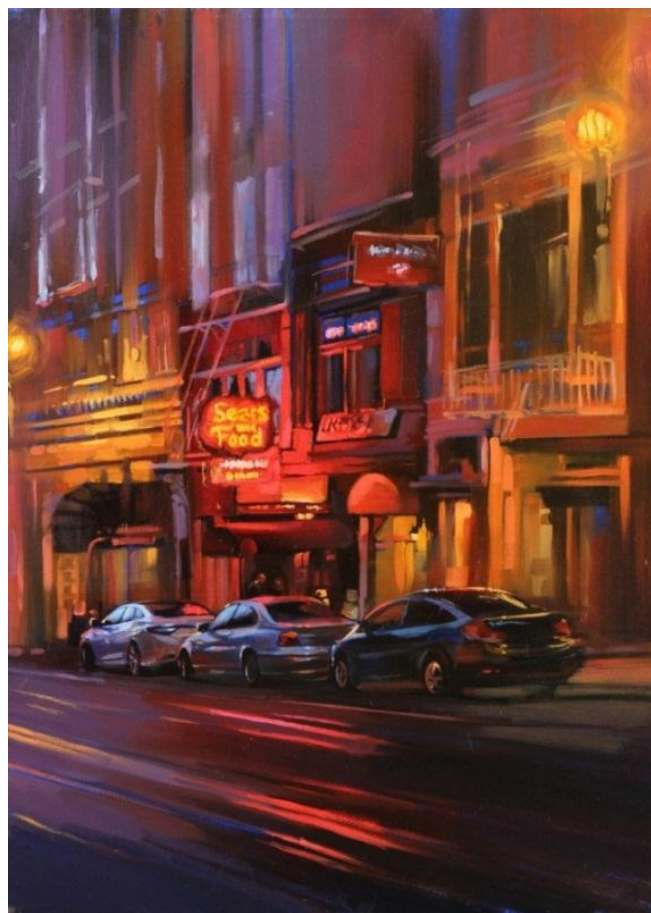

عينة رقم (6): شارع باول

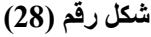

دلثاد (سماعيل، "شارع باول"، (18×24)، زيت على جنفاص، 2015، ارشيف الفنان

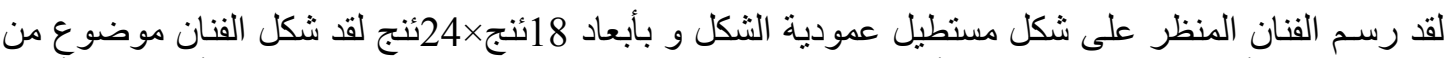

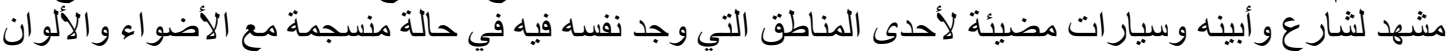

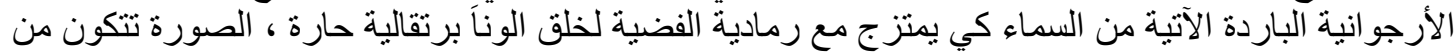




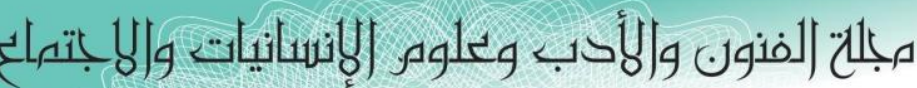
Journal of Arts, Literature, Humanities and Social Sciences

ISSN online: 2414 - 3383

ISSN print: 2616 - 3810

\section{9 نوفر \\ Volume (45)}

العدد (45)

November 2019

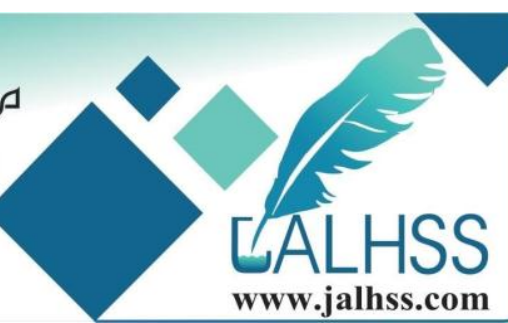

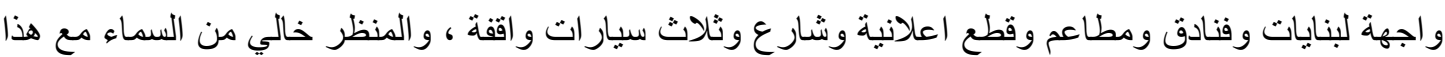

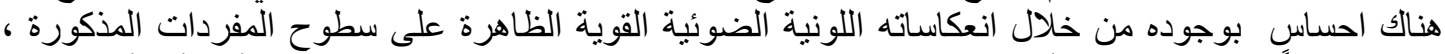

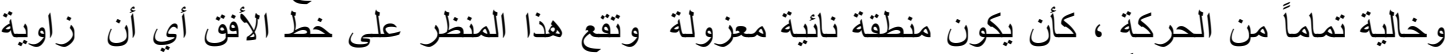

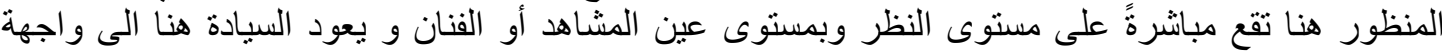

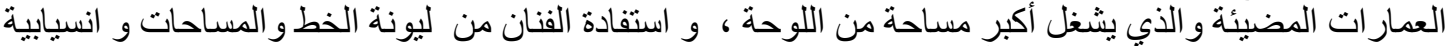

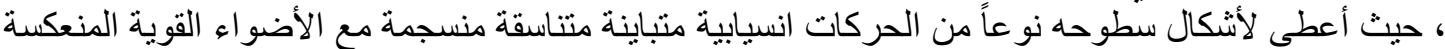

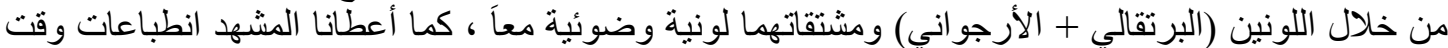

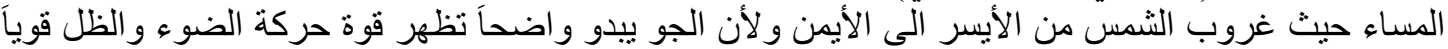

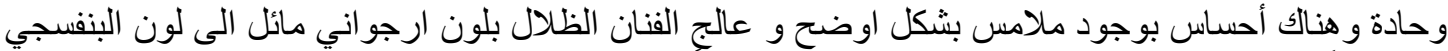

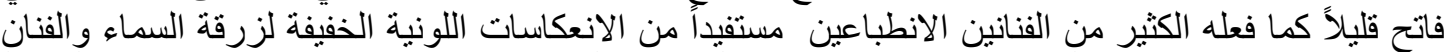

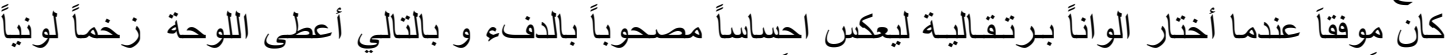

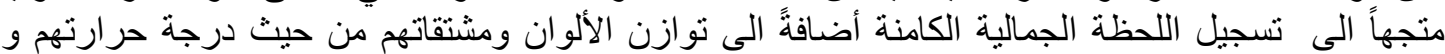

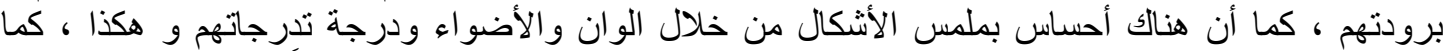

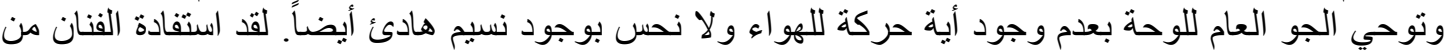

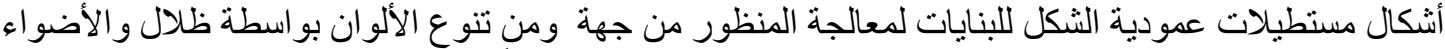

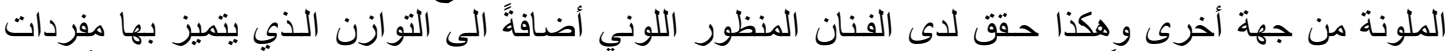

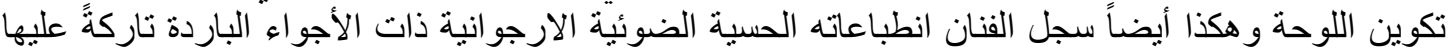

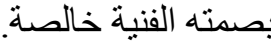

النتائج ومناقتشتها بعد تحليل العينات الفنية للفنان دلثاد اسماعيل وفق ما تضمنه الاطار النظري للبحث من الاستنتاجات ، فقد توصل الباحث الى النتائج التالية :

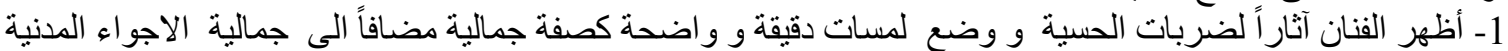

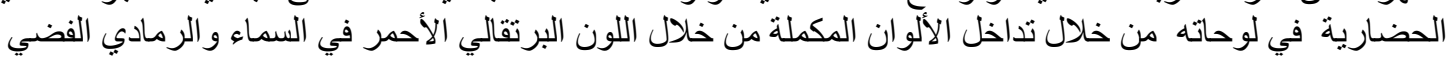

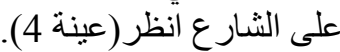

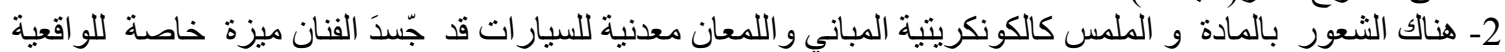

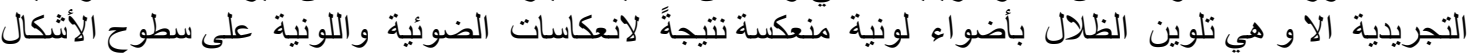

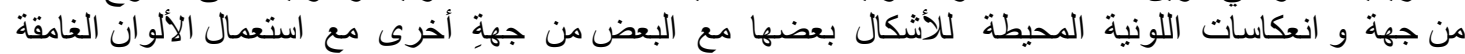

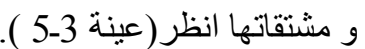

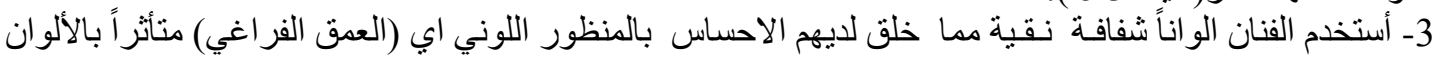

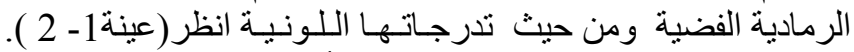

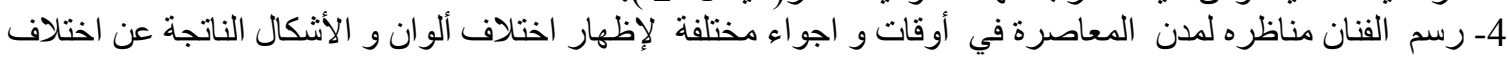

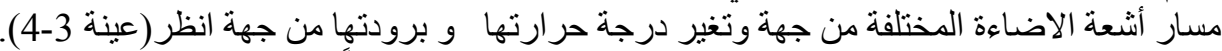

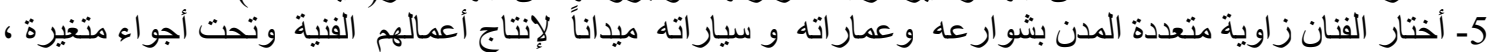

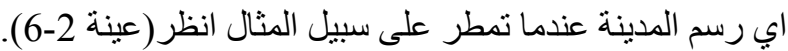

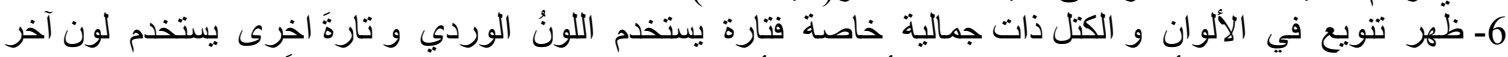

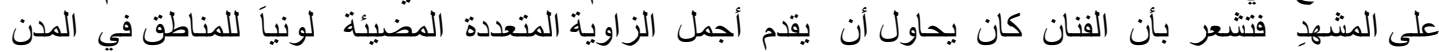

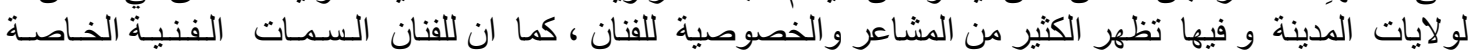

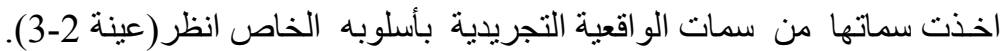

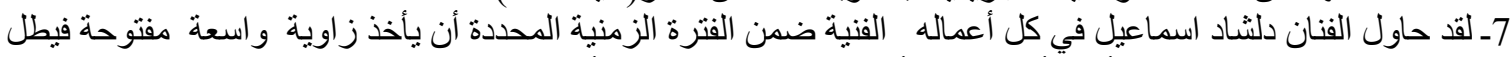

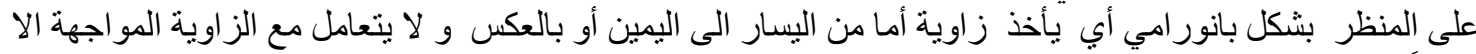

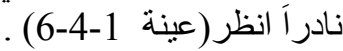

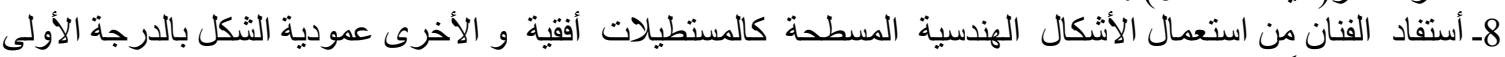
ومن ثم أنكالاً هندسية أخرى كاستخدام مثلنات ذات مساحات منفاوتة كبنية تخطيطية لأعمالـه انظر (عينة 6) . 


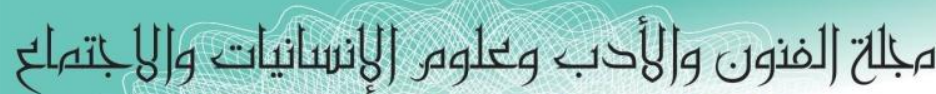
Journal of Arts, Literature, Humanities and Social Sciences

ISSN online: 2414 - 3383

ISSN print: 2616 - 3810

2019 نوفير

Volume (45)

\section{(45) (40)}

November 2019

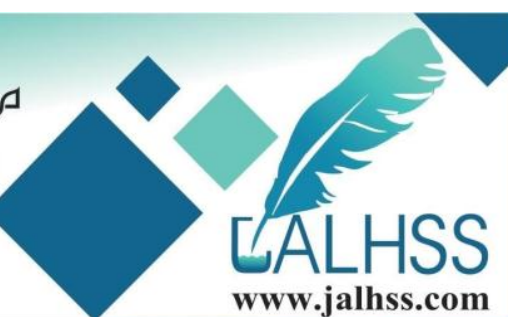

9 - ل الا يخلو لوحاته من الأشكال الآدمية إلا نادراً.

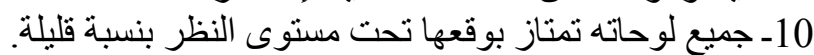

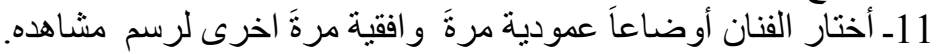

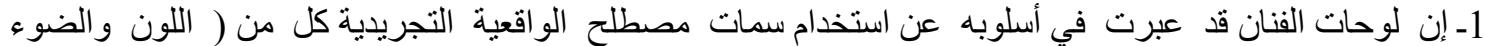

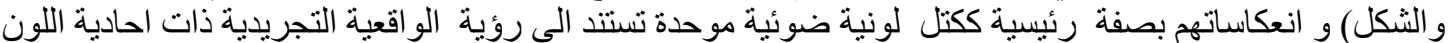

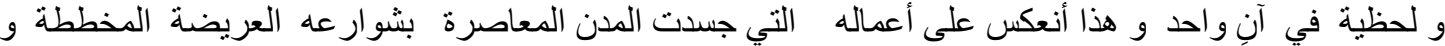

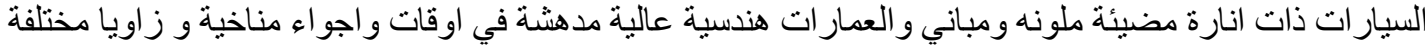

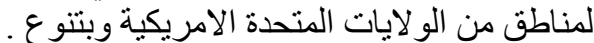

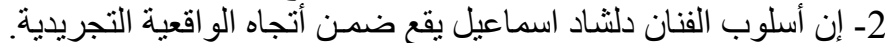

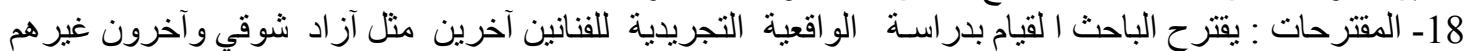
كان لهم أهمية كبيرة في تطوير الحركة التثكيلية الكردية. التوصيات: يوصي الباحث طبع هذه الدراسة من قبل الجهات المعنية لتوثيق الحركة الفنية في اقليم كردستان / العراق . قائمة الاشكال حسب ظهور ها في الاطار النظري

هذه الاشارة (-) تدل على أن مصادر تحديد ( الحجم) للوحة وسنة رسمها غير متو افرة لالى الباحث

\begin{tabular}{|c|c|c|c|c|c|}
\hline سنة الانجاز & القياسات & 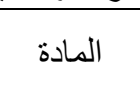 & موضوع اللوحة & اسم الفنان و هويته & $ت$ \\
\hline جاليري المبدأ 2015 & 36×36ئنج & زيت على ختب & 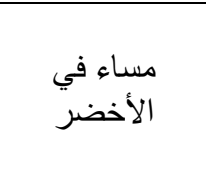 & 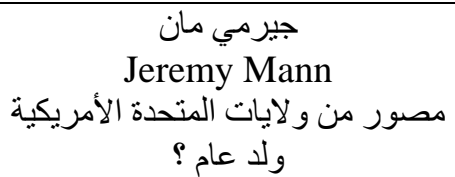 & 1 \\
\hline $\begin{array}{l}\text { جاليري } \\
\text { The john } \\
\text { pence } \\
2015\end{array}$ & 36×48 نَنج & زيت على خثب & في الأزرق & جيرمي مان & 2 \\
\hline $\begin{array}{c}\text { جاليري } \\
\text { Museed } \\
\text { Orsay } \\
187218210\end{array}$ & 172×194سم & جنفاصى زيت & انطباع شروق & كلود ، 1840 بباريس ، مصور ، ونوفي بني ، ولدينة & 3 \\
\hline ارشيف الفنان & 36×24 3ئنج & زنفاص على & اسقط شار عاً & 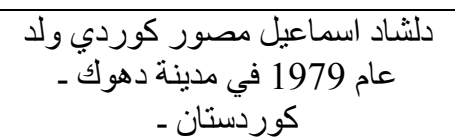 & 4 \\
\hline ارشيف الفنان & 24×36 3ئنج & زيت على & شارع بيل & دلثاد اسماعيل & 5 \\
\hline ارشيف الفنان & 8×20ئنج & زيت على & شار ع المهمة & نفسه & 6 \\
\hline ارشيف الفنان 2016 & 9×9ئنج & زيت على & $\begin{array}{c}\text { Dubos } \\
\text { صلاة }\end{array}$ & نفسه & 7 \\
\hline 2016 & 24×24 & زيت على & مساء زيتووني & جيرمي مان & 8 \\
\hline 2016 & 24×24 & زيت على & شار ع فضي & Jacob Dhein & 9 \\
\hline
\end{tabular}


مبلاتح الفنون والأذب وعلوم الإنسانيات والإبتهاع Journal of Arts, Literature, Humanities and Social Sciences

ISSN online: 2414 - 3383

ISSN print: 2616 - 3810

2019 نوفمبر

(45) (4015)

Volume (45)

November 2019

\begin{tabular}{|c|c|c|c|c|c|}
\hline & & جنفاص & & يعقوب & \\
\hline $\begin{array}{l}\text { Jenkins } \\
\text { Johnson } \\
2016\end{array}$ & 12×12ئنج & زيت على زلى & عند الغروب السريع & $\begin{array}{c}\text { بين ارونسون } \\
\text { Ben Aronson }\end{array}$ & 10 \\
\hline $\begin{array}{l}\text { Tiobor De } \\
\text { Nagy } \\
2016\end{array}$ & 12×12ئنج & زيت على زلى & عبر المدينة & نفسه & 11 \\
\hline ارشيف الفنان & 36×48ئنج & زيت على زلفاص & شنفسجي زرقاء & $\begin{array}{c}\text { مارك } \\
\text { Mark Langowski }\end{array}$ & 12 \\
\hline ارشيف الفنان & 36×48ن & زيت على زلفاص & الأخضر & Mark Lague & 13 \\
\hline ارشيف الفنان & 18×24ئنج & زيت على زلفاص & شارع السوق & نفسه & 14 \\
\hline ارشيف الفنان & 24×30ئنج & زيت على زنفاص & شار ع الأخضر & دلثـاد اسماعيل & 15 \\
\hline ارشيف الفنان 2016 & 24×24ئنج & زيت على زلى & دُش شُشس سانكي & $\begin{array}{c}\text { مارك } \\
\text { Mark Lague }\end{array}$ & 16 \\
\hline ارشيف الفنان & 24×24ئنج & زيت على زلفاص & مطر مونتريال & Mark Lague & 17 \\
\hline فر انسيسة سان & - & فوتو غراف & مرسم الفنان & 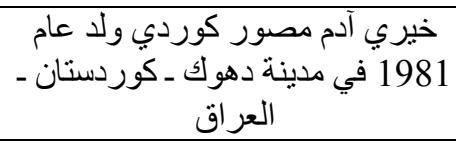 & 18 \\
\hline ارشيف الفنان & 18×24 نٔنج & 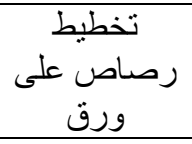 & بورتريت الفنان & 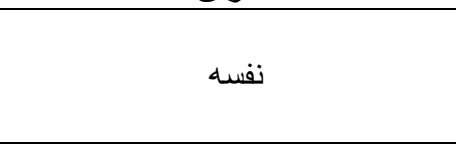 & 19 \\
\hline أرشيف الفنان & 36×48ئنج & زيت على زلى & ساعة الازدحام & $\begin{array}{c}\text { Geoffrey Johnson } \\
\text { جيفوي جونسون امريكي } \\
\end{array}$ & 20 \\
\hline أرشيف الفنان & 36×48ئنج & زيت على زلى & جير ديرسي & نفسه & 21 \\
\hline أرشيف الفنان & 30×40ئنج & زيت على زلى & احمر مع جراي & نفسها & 22 \\
\hline
\end{tabular}

قائمة اشكال العينات حسب ظهور تحليلهم

\begin{tabular}{|c|c|c|c|c|c|}
\hline عائديه العمل / سنة الانجاز & القياسات & 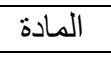 & موضوع اللوحة & اسم الفنان و هويته & $ت$ \\
\hline ارشيف الفنان & 36×24×نئنج & زنقيت & برج ألفيةِ & كوردي ولثاد اسماعيل فنان 1979 كوردينة دهان 1979 & 1 \\
\hline ارشيف الفنان & 36×24 & زنفاصى زيت & كولكستنائي & دلثاد اسماعيل & 2 \\
\hline ارشيف الفنان & 24 ×36ئنج & زليت & شاليوم الورديل في & نفسـه & 3 \\
\hline
\end{tabular}




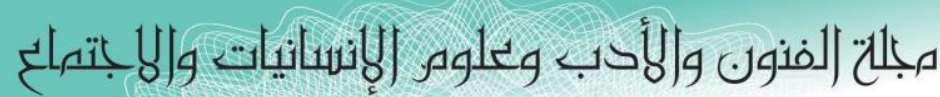

Journal of Arts, Literature, Humanities and Social Sciences

ISSN online: 2414 - 3383

ISSN print: 2616 - 3810

2019 نوفهر

(45) (40)

Volume (45)

November 2019

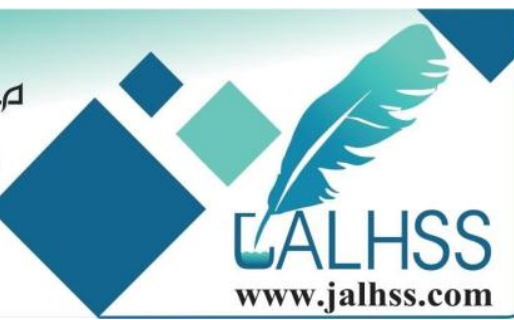

\begin{tabular}{|c|c|c|c|c|c|}
\hline & & جنفاص & & & \\
\hline ارشيف الفنان & 24×36ئنج & جنفاصى زيت & شارع فريمونت & نفسه & 5 \\
\hline ارشيف الفنان & 24 ×36 36 نجج & زنفاصى زيت & شارع فولسوم & نفسه & 6 \\
\hline ارشيف الفنان & 18×24ئنج & زنفاصى زيت & شار ع باول & نفسه & 6 \\
\hline
\end{tabular}

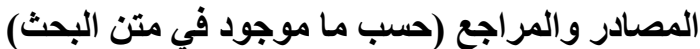

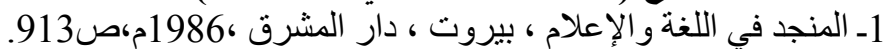

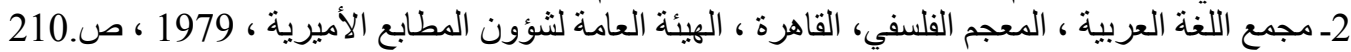

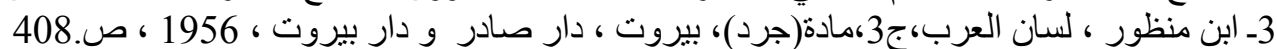

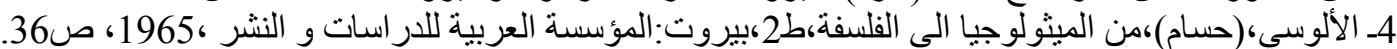

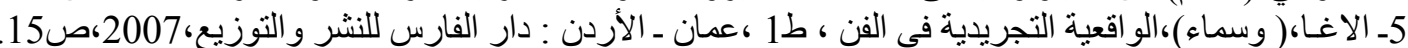

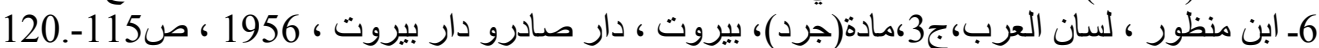

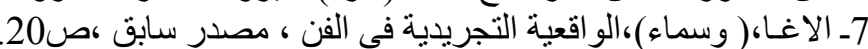
8ـ هاوزر ، آرنولد ،الفن والمجتمع عبر التأريخ ،تر :فؤاد زكريا ،ج ،مصر :الهيئة المصرية العامة ،1971،

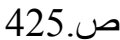

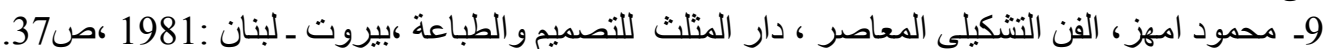

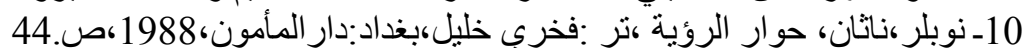

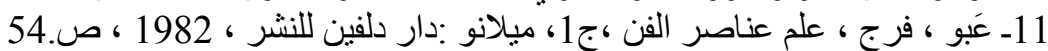

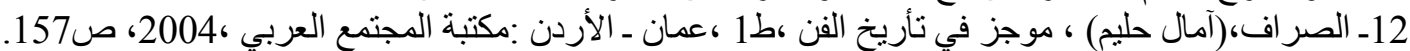

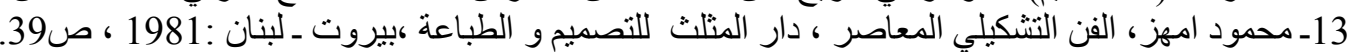

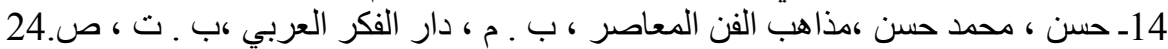

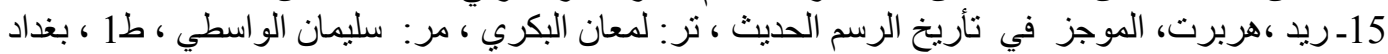
:

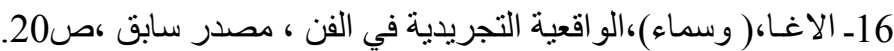

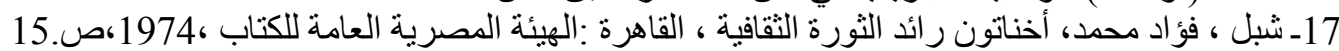

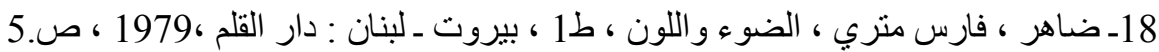

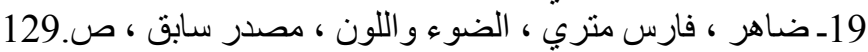

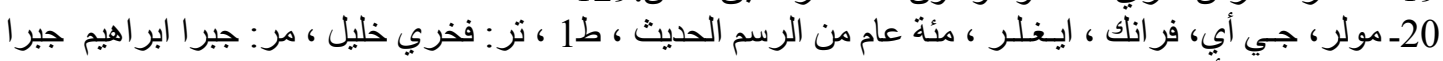

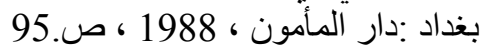

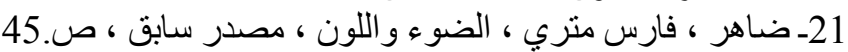

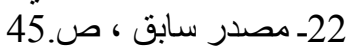

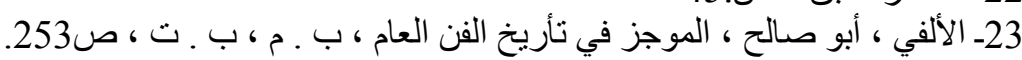

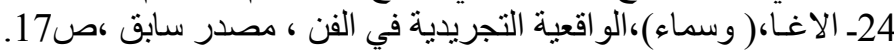

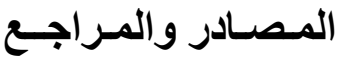

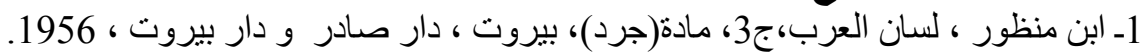

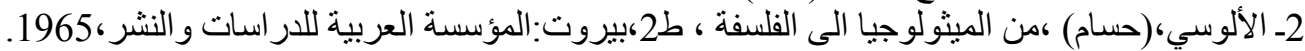

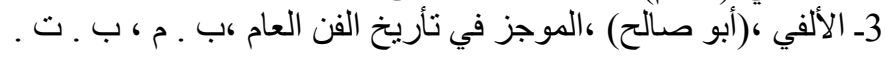



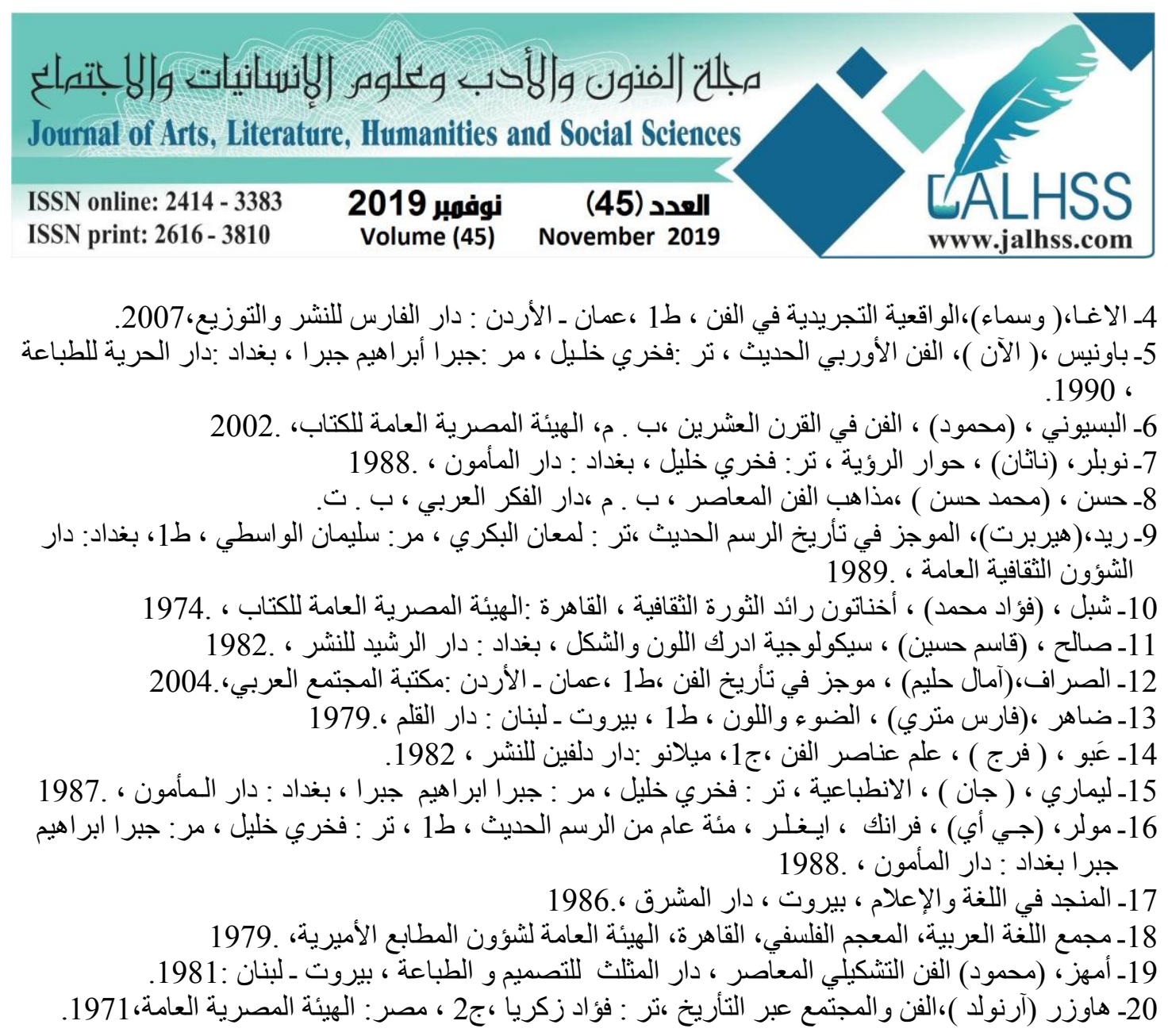

\section{References}

1- Ibn Manzoor, the tongue of the Arabs, article (inventory), Beirut, Dar Sader and Dar Beirut, 1956.

2 Alusi, (Hossam), from mythology to philosophy, Beirut: Arab Foundation for Studies and Publishing, 1965.

3 millennial, (Abu Saleh), a summary in the history of public art, b. M, b. T .

4- Agha, (and sky), abstract realism in art, Amman, Jordan: Dar Al-Fares for Publishing and Distribution, 2007.

5. Bowness, (now), Modern European Art, tr: Fakhri Khalil, Mr. Jabra Ibrahim Jabra, Baghdad: Freedom House, 1990.

6 Bassiouni, (Mahmoud), Art in the twentieth century, b. M, General Egyptian Book Organization, 2002.

7.Nobler, (Nathan), dialogue of vision, see: Fakhri Khalil, Baghdad: Dar al-Ma'mun, 1988.

8. Hassan, (Mohammed Hassan), doctrines of contemporary art, b. M, Dar Arab Thought.

9 Reid, (Herbert), a summary in the history of modern painting, tr: luminosity Bakri, Mr:

Sulaiman al-Wasiti, Baghdad: General Cultural Affairs, 1989.

10- Shebl, (Fouad Mohamed), Akhenaten, pioneer of the Cultural Revolution, Cairo: The Egyptian General Book Organization, 1974.

11. Saleh, (Qasim Hussein), the psychology of color and shape, Baghdad: Dar AlRasheed for Publishing, 1982.

12 Sarraf, (Amal Halim), a summary in the history of art, Amman - Jordan: Library of Arab Society, 2004. 


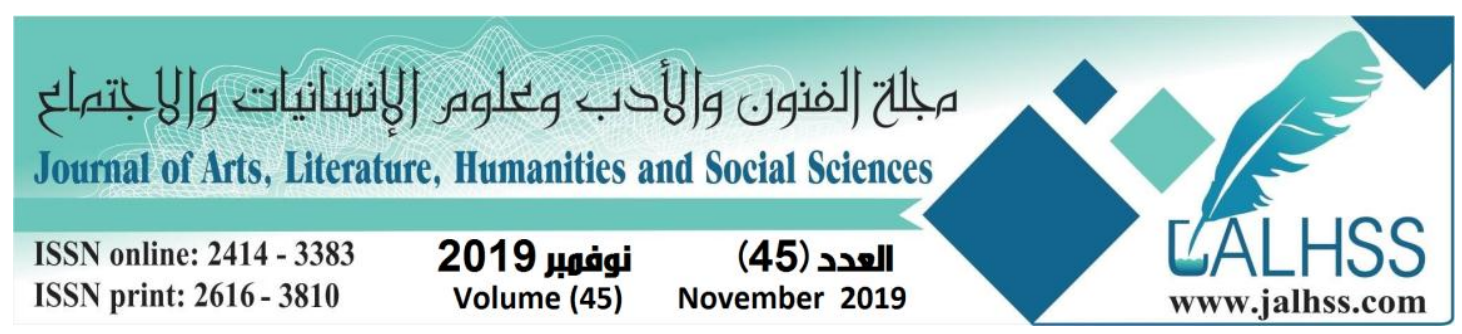

13. Daher, (Faris Metri), light and color, Beirut-Lebanon: Dar Al-Qalam, 1979.

14, Abbou, (Faraj), science elements of art, c 1, Milan: House of Delphine Publishing, 1982.

15.Limari, (Jean), Impressionism, see: Fakhri Khalil, Mr: Jabra Ibrahim Jabra, Baghdad: House of Mamoun, 1987.

16.Muller, (GE), Frank, Egler, a hundred years of modern painting, i 1, tr: Fakhri Khalil, Mr: Jabra Ibrahim Jabra Baghdad: Dar al-Ma'mun, 1988.

17- Upholstered in Language and Media, Beirut, Dar Al-Mashreq, 1986.

18- Arabic Language Complex, Philosophical Dictionary, Cairo, General Authority for Emiri Printing Press Affairs, 1979.

19- Amhaz, (Mahmoud) Contemporary Fine Art, Triangle House for Design and Printing, Beirut, Lebanon: 1981.

20. Hauser (Arnold), Art and Society Through History, Tr .: Fouad Zakaria, Vol. 2, Egypt: The Egyptian General Authority, 1971. 